\author{
UNIVERSIDADE DE SÃO PAULO \\ FACULDADE DE FILOSOFIA, LETRAS E CIÊNCIAS HUMANAS \\ DEPARTAMENTO DE LETRAS ORIENTAIS \\ PROGRAMA DE ESTUDOS JUDAICOS E ÁRABES
}

JOÃO GALLEGOS FIUZA

Os conflitos no Oriente Médio e o surgimento do Estado Islâmico do Iraque e da Síria

São Paulo

2020 


\section{JOÃO GALLEGOS FIUZA}

Os conflitos no Oriente Médio e o surgimento do Estado Islâmico do Iraque e da Síria

Dissertação apresentada ao Programa de PósGraduação em Estudos Judaicos e Árabes do Departamento de Letras Orientais da Faculdade de Filosofia, Letras e Ciências Humanas, da Universidade de São Paulo, como parte dos requisitos para obtenção do título de Mestre em Estudos Árabes.

Orientadora: Prof. $^{\text {a }}$ Dr. ${ }^{\text {a }}$ Arlene Elizabeth Clemesha.

São Paulo 
Autorizo a reprodução e divulgação total ou parcial deste trabalho, por qualquer meio convencional ou eletrônico, para fins de estudo e pesquisa, desde que citada a fonte.

Catalogação na Publicação

Serviço de Biblioteca e Documentação

Faculdade de Filosofia, Letras e Ciências Humanas da Universidade de São Paulo

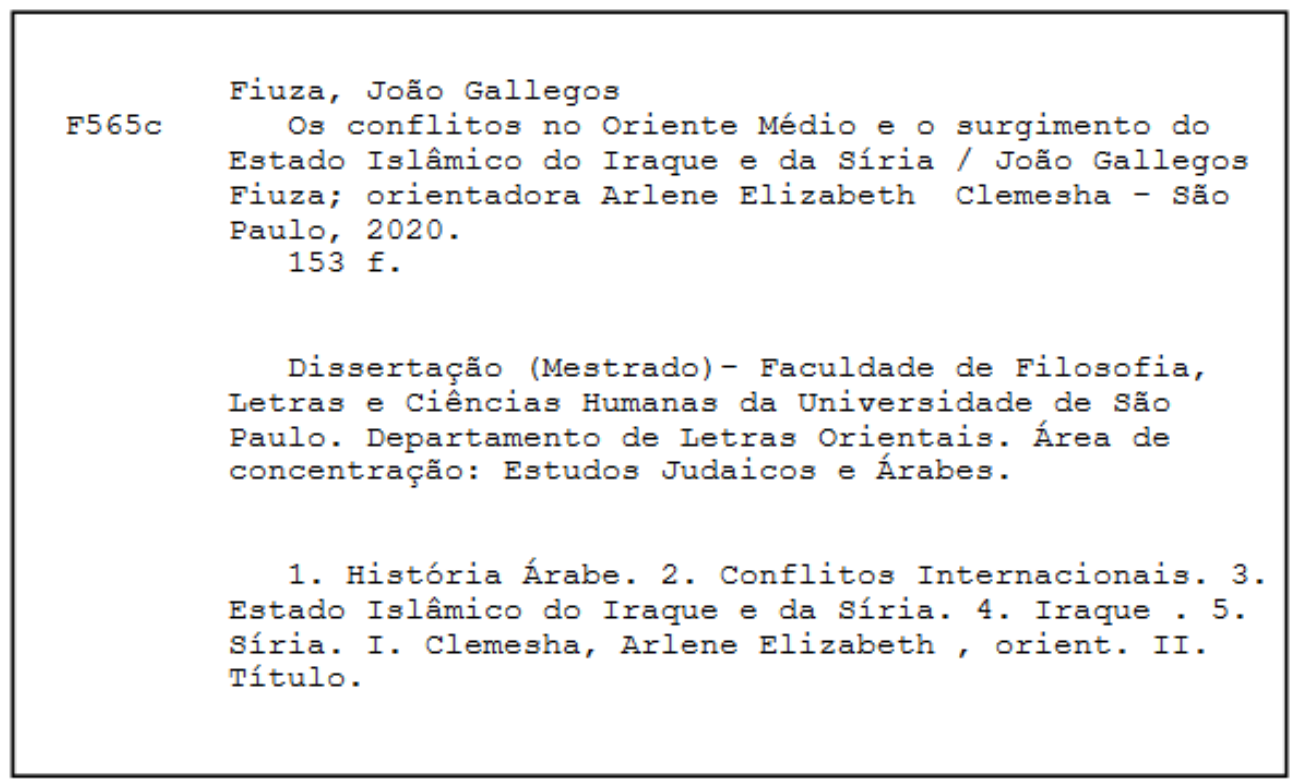




\section{ENTREGA DO EXEMPLAR CORRIGIDO DA DISSERTAÇÃO/TESE}

\section{Termo de Ciência e Concordância do (a) orientador (a)}

\section{Nome do (a) aluno (a): João Gallegos Fiuza}

Data da defesa: 06/05/2020

Nome do Prof. (a) orientador (a): Arlene Elizabeth Clemesha

Nos termos da legislação vigente, declaro ESTAR CIENTE do conteúdo deste EXEMPLAR CORRIGIDO elaborado em atenção às sugestões dos membros da comissão Julgadora na sessão de defesa do trabalho, manifestando-me plenamente favorável ao seu encaminhamento e publicação no Portal Digital de Teses da USP.

São Paulo, 31/05/2021

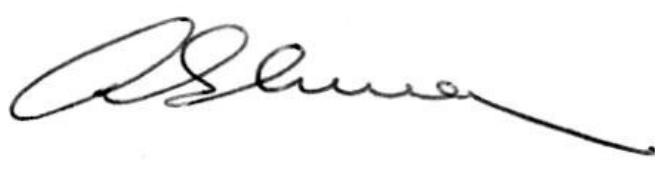

(Assinatura do (a) orientador (a) 
FIUZA, João Gallegos. Os conflitos no Oriente Médio e o surgimento do Estado

Islâmico. Dissertação (Mestrado) apresentada à Faculdade de Filosofia, Letras e Ciências Humanas da Universidade de São Paulo para obtenção do título de Mestre em Estudos Árabes.

Aprovado em:

Banca Examinadora:

Prof. Dr. Instituição

Julgamento Assinatura

Prof. Dr. Instituição Julgamento Assinatura

Prof. Dr. Instituição Julgamento Assinatura

Prof. Dr. Instituição Assinatura 


\section{AGRADECIMENTOS}

A todos aqueles que colaboraram direta ou indiretamente com a realização desta pesquisa.

A meus pais, por terem despertado em mim a sede pelo saber.

À Prof. ${ }^{a}$ Dr. ${ }^{a}$ Arlene Elizabeth Clemesha, minha orientadora, que me abriu as portas ao mestrado na Universidade de São Paulo, me ofertando as melhores condições para desenvolver meu potencial nesta Universidade.

Aos meus professores da Universidade de São Paulo, pela importante contribuição para com a minha formação acadêmica.

À Juliana, minha namorada, por todo o apoio durante a realização deste trabalho.

Aos colaboradores do Departamento de Letras Orientais da Universidade de São Paulo, por toda ajuda e apoio em diversas demandas ao longo do período de aulas e de pesquisas. 
Se a alma é imparcial em receber a informação, ela dedica a essa informação a parte da investigação crítica que a informação merece, e sua verdade ou inverdade então torna-se clara.

No entanto, se a alma estiver infectada pelo partidarismo com relação a determinada opinião ou seita, ele aceita sem hesitação a informação que lhe agrada. Preconceitos e partidarismo obscurecem a capacidade crítica e impedem a investigação crítica. Os resultados são que as falsidades são aceitas e transmitidas.

Ibn Khaldun (1332-1406)

O passado se assemelha ao futuro mais do que uma gota d'água se assemelha a outra.

Ibn Khaldun (1332-1406) 


\section{RESUMO}

FIUZA, João Gallegos. Os conflitos no Oriente Médio e o surgimento do Estado Islâmico do Iraque e da Síria. 2020. 153 f. Dissertação (Mestrado) - Faculdade de Filosofia, Letras e Ciências Humanas, Universidade de São Paulo, São Paulo, 2020.

A presente dissertação se pauta na história árabe contemporânea, concentrando-se no Iraque e na Síria, pesquisando os elementos que permitiram o surgimento do Estado Islâmico do Iraque e da Síria no início do século XXI. Discutem-se assuntos relativos ao extremismo religioso islâmico para então estudar a situação atual dos dois países em questão. A partir daí se pesquisam diferentes pontos relativos à organização em tela, abordando-se questões históricas relativas à religião, a ideologias e à sócio-política, para que então sejam analisados os elementos que influenciaram e permitiram o surgimento da organização que é objeto deste estudo.

Palavras-chave: Estado Islâmico. Iraque. Síria. Salafismo. Jihadismo. 


\section{ABSTRACT}

FIUZA, João Gallegos. The Conflicts in the Middle East and the Rise of the Islamic State of Iraq and Syria. 2020. 153 f. Dissertation (Master's Degree) - Faculdade de Filosofia, Letras e Ciências Humanas, Universidade de São Paulo, São Paulo, 2020.

This dissertation is based on contemporary Arabic history, focusing on Iraq and Syria, researching the elements that allowed the emergence of the Islamic State of Iraq and Syria in the early 21 st century. Issues relating to Islamic religious extremism are discussed to study the current situation of the two cited countries. Further, different points related to the organization in question are researched, addressing historical issues related to religion, ideologies and sociopolitics, to then analyze the elements that influenced and allowed the emergence of the organization which is object of this study.

Keywords: Islamic State. Iraq. Syria. Salafism. Jihadism. 


\section{SUMÁRIO}

TRANSLITERAÇÃO

1 INTRODUÇÃO 12

2 DEFINIÇÕES E DESENVOLVIMENTOS DO EXTREMISMO RELIGIOSO NO ORIENTE MÉDIO NA PASSAGEM DO SÉCULO XX-XXI 16

$\begin{array}{ll}2.1 \text { TERRORISMO } & 26\end{array}$

2.1.1 Terrorismo Islâmico 31

3 O IRAQUE CONTEMPORÂNEO 38

3.1 QUESTÕES DE ECONOMIA, POLÍTICA E SOCIEDADE 38

3.2 RELIGIÃO NO IRAQUE $\quad 41$

3.3 INTERVENÇÃO MILITAR ANGLO-AMERICANA 42

$\begin{array}{ll}3.4 \text { A AL-QAEDA NO IRAQUE } & 50\end{array}$

3.4.1 A influência de Al-Zarqawi $\quad 55$

3.5 O SURGIMENTO DO ESTADO ISLÂMICO DO IRAQUE 67

$\begin{array}{ll}\text { 3.5.1 A influência de Al-Baghdadi } & 70\end{array}$

4 A SÍRIA CONTEMPORÂNEA

4.1 QUESTÕES DE ECONOMIA, POLÍTICA E SOCIEDADE 75

$\begin{array}{ll}\text { 4.2 RELIGIÃO NA SÍRIA } & 77\end{array}$

4.3 A PRIMAVERA ÁRABE NA SÍRIA $\quad 80$

5 O ESTADO ISLÂMICO DO IRAQUE E DA SÍRIA

5.1 QUESTÕES IDEOLÓGICO-RELIGIOSAS E SOCIAIS LIGADAS O SURGIMENTO DO ESTADO ISLÂMICO 92

5.2 QUESTÕES POLÍTICAS LIGADAS AO SURGIMENTO DO ESTADO ISLÂMICO DO IRAQUE E DA SÍRIA

5.3 FINANCIAMENTO AO ESTADO ISLÂMICO DO IRAQUE E DA SÍRIA 
5.4 QUESTÕES MILITARES LIGADAS AO SURGIMENTO DO ESTADO ISLÂMICO DO IRAQUE E DA SÍRIA $\quad 127$

6 CONSIDERAÇÕES FINAIS 137

$\begin{array}{ll}\text { BIBLIOGRAFIA } & 142\end{array}$ 


\section{TRANSLITERAÇÃO}

Os nomes árabes já consagrados em língua portuguesa não serão transliterados, como os nomes próprios de cidades e de pessoas. Os nomes de autores que constantes na bibliografia também não serão transliterados. Os demais nome próprios e termos árabes serão transliterados conforme o artigo Para uma Romanização Padronizada de Termos Árabes em Textos de Língua Portuguesa, Por Safa Abou-Chahla Jubran (2004).

\section{Guia de pronúncia para a transliteração}

\section{Consoantes e semiconsoantes}

b como o $b$ do português $b a r$

t como o $t$ do português taco

t como o th do inglês think

j como o $j$ do inglês jam

ḥ como o $h$ do inglês heart, pronunciado de forma enfática

h como o $j$ do espanhol Javier

d como o $d$ do inglês $d a d$

d como o th do inglês them

$\mathbf{r}$ como o $r$ do português arara

s como o $s$ do português sal, ou o

dígrafo ss no português assim

š como o sh do inglês shine

ș como o $s$ do português sol, ou do inglês saw

ḍ como o $d$ do inglês $d o c k$

ṭ como o $t$ do inglês talk ou do português toco

ḍ como o th do inglês thorough
' como o breve som entre os dois $a$ do português brasileiro caatinga $\dot{\mathbf{g}}$ como o $r$ no francês parisiense Paris

q como o $c$ no inglês core ou cough

$\mathbf{k}$ como o $k$ no inglês key ou o $c$ em $c a t$

$\mathbf{l}$ como o $l$ do inglês lack

$\mathbf{m}$ como o $m$ do inglês mock

n como o $n$ do inglês noon

$\mathbf{h}$ como o $h$ do inglês behaviour

' parada glotal como a que se faz para (não) pronunciar o $h$ no inglês hour .

w como o $w$ do inglês war

$\mathbf{y}$ como o breve $y$ que se pronuncia antes da primeira sílaba no inglês university

\section{Vogais}

$\overline{\mathbf{a}}$ como o primeiro $a$ de $\operatorname{cas} a$

a como o segundo a de casa

$\overline{\mathbf{u}}$ como o $u$ de urso

u como o $u$ de tulipa

ì como o í de açaí

i como o $i$ de caritê 


\section{INTRODUÇÃO}

Essa pesquisa tem por objetivo estudar o desenvolvimento dos conflitos civis em curso na Síria e no Iraque, no que diz respeito à conjuntura que permitiu o surgimento e o desenvolvimento do autoproclamado califado ${ }^{1}$ conhecido por Estado Islâmico $^{2}$. Esta organização, classificada segundo Fawaz Gerges, dentre outros autores, como salafistajihadista, constitui-se em uma das diversas organizações do mesmo tipo surgidas nos últimos trinta anos em decorrência da propagação das ideologias salafista e jihadista, assim como a mais conhecida organização do tipo, a Al-Qaeda (2016, p. 4).

O Estado Islâmico diferencia-se dos demais grupos do mesmo tipo devido à extrema instrumentalização da violência, tanto para fins de recrutamento quanto para impactar seus opositores (Cf. GERGES, 2016, p. IX-X). As principais características dessa organização serão expostas e discutidas mais adiante, assim como as ideologias em que se apoia e os movimentos aos quais se relaciona. Por meio de uma pesquisa eminentemente histórica, mas abrangendo importantes elementos sócio-políticos relacionados ao assunto, o presente estudo visa analisar os acontecimentos que permitiram a formação de um ambiente político e social propenso ao surgimento de uma organização que, baseada em uma vertente ideológico-religiosa fundamentalista islâmica, propôs-se a conquistar, num primeiro momento, os territórios do Levante ${ }^{3}$.

Uma vez que o surgimento do Estado Islâmico se deve aos fatos históricos recentes havidos na Síria e no Iraque, esta investigação abordará fatos relativos à Guerra Civil síria, cuja origem se deve ao movimento conhecido por Primavera Árabe, bem como à Guerra do Iraque, a qual provocou o surgimento de grupos insurgentes que seriam o embrião daquilo que se tornaria mais tarde o Estado Islâmico. Esta investigação tem por escopo uma análise sistemática para se chegar a uma compreensão adequada acerca dos acontecimentos que levaram à atual situação do Iraque e da Síria, no que diz respeito às

\footnotetext{
${ }^{1}$ Referente a califa, termo árabe que significa "sucessor". Foi usado para designar os sucessores do Profeta Muhammad, a partir de sua morte em 632 d.C. O termo denota ao mesmo tempo um Chefe de Estado e líder teocrático (Cf. ZAMAN, 2004, p. 116-123).

2 Organização conhecida como Estado Islâmico do Iraque e do Levante, Estado Islâmico do Iraque e da Síria ou ainda pelo acrônimo árabe Daesh (al-Dawlah al-Islāmīyah fĩ al-'Irāq wa-al-Shām), o qual carrega certo sentido pejorativo (Cf. GERGES, 2016, p. IX).

${ }^{3}$ Região geográfica correspondente aos territórios atuais do Líbano e da Síria (Cf. ROBERTS, 2010).
} 
mudanças causadas pelo desenvolvimento dos conflitos advindos dos fenômenos históricos supramencionados, bem como das questões impostas às populações e Estados da região pelos grupos que originariam o Estado Islâmico. Isso significa constatar as circunstâncias que permitiram o surgimento da organização objeto desta dissertação. Desse modo, estudar-se-ão mormente aos fenômenos históricos que levaram o Oriente Médio - mais especificamente a Síria e o Iraque - a apresentar uma conjuntura favorável ao surgimento e à expansão de tal organização.

O desenvolvimento desta dissertação se dará, em linhas gerais, partindo-se do estudo de como a Guerra do Iraque contribuiu para a formação de grupos que mais tarde viriam a se reunir e formar o Estado Islâmico. Num segundo momento, analisar-se-á de que forma a guerra civil síria colaborou para a fusão da Frente Al-Nusra - um grupo também salafista-jihadista atuante na Síria, constituindo-se como filial da Al-Qaeda na Síria - ao Estado Islâmico do Iraque, de modo a se formar o Estado Islâmico do Iraque e da Síria (Cf. GERGES, 2016, p. 10). Posteriormente, avaliar-se-ão as influências de questões ideológico-religiosas, socioeconômicas e políticas que possibilitaram que se colocasse em prática o projeto que visava o estabelecimento de um novo califado que viesse a se denominar Estado Islâmico.

É importante que se diferencie, quando da utilização do termo Estado Islâmico, daquilo que se entende por Estado, conforme o conceito weberiano (Cf. SILVA e SILVA, 2099, p. 115-6). Segundo Max Weber, deve-se entender por Estado uma instituição detentora do monopólio da violência legítima, bem como do poder de legislar, possuindo um território definido onde exerce sua dominação legal. Seguindo ainda esses preceitos, em um Estado moderno estariam presentes duas características: a existência de um aparato administrativo cuja função seria prestar serviços públicos, e o monopólio legítimo da força. Dentro dessa perspectiva, temos que o Estado é o único a poder empregar a violência legalmente, passando esta a ser um instrumento de controle da sociedade. Assim, o Estado Moderno é visto tanto como a organização da sociedade em um governo autônomo quanto um aparelho que governa essa sociedade. $\mathrm{O}$ autodenominado Estado Islâmico não se encaixa, assim, em qualquer definição aceita de Estado moderno, tampouco possui o reconhecimento político da comunidade internacional.

Há que se notar ainda que Estado Islâmico da Síria e do Iraque é a tradução ao português do árabe al-Dawla al-Islamiyyah fi al-Iraq wa al-Sham, termo este cunhado 
pela própria organização, no qual o termo al-Dawla possui uma conotação própria na língua árabe, que não corresponde necessariamente ao que se entende por Estado. Diante de tudo isso, só se pode entender o nome (cujo acrônimo mais comumente empregado, ISIS, deriva da tradução ao inglês, Islamic State of Iraq and Syria) como referência a uma organização política com pretensões estatais, mas não a um Estado constituído.

O método científico ora utilizado é o método histórico, por meio do qual se investigam instituições, acontecimentos e processos passados para se verificar sua influência no mundo atual (Cf. BARROS, 2015, p. 91). Para tanto, a investigação científica se desenvolve em torno da necessidade de se discutirem as possíveis respostas aos problemas apresentados. Diante da problemática anteriormente apresentada, as hipóteses estabelecidas atendem a processos de observação sistematizada, de maneira a se examinarem os dados obtidos das fontes pesquisadas, os quais serão analisados conforme tal método (Cf. BARROS, 2015, p. 134).

Com relação ao enquadramento teórico historiográfico utilizado nesta pesquisa, objetivando a compreensão quanto à maneira como os conflitos no Oriente Médio levaram ao surgimento do Estado Islâmico do Iraque e da Síria, este se baseia na questão do neocolonialismo. Através deste enquadramento se abordam relações de dominação econômica, social, cultural e política por parte de um antigo poder colonial sobre Estados agora independentes (Cf. VIOTTI e KAUPPI, 2013, p. 131). Este conceito se aplica à temática desta pesquisa de acordo como renomado historiador Bernard Lewis, que argumenta que o declínio do mundo árabe se dá em razão das políticas póscolonialistas ocidentais após 1945. Mais detalhadamente, coloca o historiador que nas últimas décadas do século XX uma combinação de crescimento populacional nos Estados árabes, estagnação econômica, aumento da interferência estrangeira e fracasso de políticas socialistas pan-árabes, acabaram por impulsionar o desenvolvimento de ideais islamistas, os quais atraíram o apoio da população mais jovem e de pessoas engajadas politicamente (Cf. LEWIS, 2004). Esta fundamentação teórica alicerça este trabalho, sendo que a avaliação das hipóteses ora formuladas se dará a partir de uma perspectiva neocolonialista, para a qual as obras de Bernard Lewis em muito contribuem. Nesse sentido, é interessante notar ainda, de forma a complementar e a reforçar tal teoria, o entendimento de outro importante historiador, também especialista em Oriente Médio, James Gelvin. Em sua análise acerca da influência neocolonial de Estados ocidentais sobre os países islâmicos, tal processo produziu formas conflitantes de nacionalismo, as quais se baseavam em diferentes conceitos quanto a soberania, a autodeterminação e a 
segurança. Consequentemente, vários grupos sociais desenvolveram uma elite liberal em sua forma clássica, procurando assim a independência nacional de seus antigos poderes coloniais, apesar de almejarem manter laços benéficos junto aos estados ocidentais e os mercados que controlavam (Cf. GELVIN, 1997). 


\section{DEFINIÇÕES E DESENVOLVIMENTOS DO EXTREMISMO RELIGIOSO NO ORIENTE MÉDIO NA PASSAGEM DO SÉCULO XX-XXI}

As fronteiras atuais da maioria dos países do Oriente Médio são o retrato de cerca de um século de interferência estrangeira na região, desde o desaparecimento do Império Otomano em 1922, o que permitiu o início da dominação da Grã-Bretanha e da França. Estes transformaram grande parte do Oriente Médio em suas colônias, fazendo prevalecer suas próprias necessidades e interesses (Cf. CATHERWOOD, 2006, p. 154). Os processos de dominação exercidos pelos colonizadores europeus acabaram por causar diversos episódios de revolta por parte dos habitantes das terras ocupadas, muitas vezes com o uso de grande violência. No caso específico do império britânico, já há registros de que este teve de lidar com atos de terrorismo ${ }^{4}$ durante os últimos anos em que exerceu dominação política e militar, em razão de movimentos nacionalistas que visavam persuadir as tropas britânicas a deixar os territórios ocupados. Como explica Bernard Lewis,

o século XX trouxe uma renovação de tais ações no Oriente Médio, embora de diferentes tipos e para diferentes finalidades, e o terrorismo passou por várias fases. Durante os últimos anos do Império Britânico, a Grã-Bretanha imperial enfrentou movimentos terroristas em suas dependências do Oriente Médio que representavam três culturas diferentes: gregos no Chipre, judeus na Palestina e árabes em Áden. Todos os três tiveram motivação nacionalista, ao invés de religiosa. Embora muito diferentes em suas origens e circunstâncias políticas, os três foram substancialmente idênticos em suas táticas. Sua finalidade era persuadir o poder imperial de que permanecer na região não valia a pena, pois lhe custaria sangue. Seus métodos eram atacar militares e, em menor grau, pessoal administrativo e suas instalações. Todos os três operavam apenas dentro de seu próprio território e, geralmente, evitavam danos colaterais. Todos tiveram sucesso em seus esforços (2004, p. 136).

\footnotetext{
${ }^{4}$ Nesta dissertação, em razão do caráter extremamente politizado do termo terrorismo, este será empregado de acordo com a perspectiva instrumental apresentada por Martha Crenshaw em seu livro Explaining Terrorism: Causes, Processes and Consequences (2011), dentro da qual o fator determinante para que se defina uma ação violenta como terrorismo não é a ideologia ou a identidade de seu autor, e sim o método por ele utilizado. Dentro dessa visão, terrorismo pode ser entendido como um ato de violento que resulta na percepção de terror às vítimas diretas e indiretas do ato. O termo carece de consenso para sua definição, motivo pelo qual há marcantes diferenças entre os estudiosos do assunto. Por tais motivos, uma discussão mais extensa acerca do tópico será feita no capítulo 2 desta pesquisa.
} 
Portanto, o uso da violência para obter um ganho político específico não foi exclusividade de grupos fundamentalistas islâmicos na região, mas certamente passou a ser empregado por estes no século $\mathrm{XX}$, tanto em lutas internas quanto contra o colonialismo europeu, cuja penetração no Oriente Médio, desde o século XIX, trouxe grande insatisfação às sociedades dessa região. Tal condição viria a se agravar ainda mais após o período da colonização franco-britânica, com a interferência dos Estados Unidos da América em alguns países da região.

Desde o século XIX pôde-se ver o surgimento de movimentos fundamentalistas dentro do islamismo. Observa Margaret Nydell (2012, p. 99) que atualmente, para se referir a tal forma de pensamento extremista, são popularmente utilizados diferentes termos - muitas vezes de forma incorreta -, como islamismo militante, islã político ou apenas jihadismo. Contudo, o termo fundamentalismo acabou por ser o mais utilizado para se definir o pensamento extremista islâmico, compreendendo ideias sobre o retorno do modo de vida de seus fiéis à forma descrita nos registros originais do Corão, segundo a interpretação particular do grupo em questão. A maioria dos grupos jihadistas expressa sua fé através do salafismo, uma forma ainda mais ascética e rigorosa de extremismo ideológico-religioso. Complementa tal ideia Wiktorowicz, mencionando que isso significa que tais grupos se baseiam principalmente no salafismo para legitimar seus atos de terrorismo por meio de sua interpretação particular do Corão ${ }^{5}$, das hadiths ${ }^{6}$, e de acordo com obras de diferentes escritores partidário de tal ideologia (2001, p. 22). Este entendimento por parte de Nydell vem a apresentar diferentes denominações, ligadas a distintas perspectivas com relação às organizações do tipo ora estudado, o que é interessante do ponto de vista acadêmico em razão da diversidade de conceitos que podem estar envolvidos quando de estudos desta natureza.

Tratando-se de tais definições com mais detalhe, tem-se que o fundamentalismo islâmico trata-se de fenômeno complexo que carece de unanimidade quanto a sua definição. $\mathrm{O}$ fundamentalismo religioso, de forma geral, pode ser visto como um meio para a progressiva mudança social, visando a melhoria do bem-estar das camadas mais pobres de determinada sociedade e o incremento da participação política

\footnotetext{
5 Do árabe "recitação." Livro sagrado do Islã, considerado pelos muçulmanos como a palavra literal de Deus à humanidade pelo profeta Maomé no ano de 610. Trata-se, da revelação divina de Deus à humanidade e a base para que os muçulmanos vivam de modo correto e justo (Cf. MARTIN, 2004, p. 753).

${ }^{6}$ Do árabe "fala". Tratam-se de ensinamentos do profeta Maomé acerca da vida islâmica, conforme a narrativa dos seus primeiros seguidores. Podem embasar documentos legais e históricos acerca dos primórdios do Islã (Cf. MOTZKI, 2004, p. 285-8)
} 
de forma maciça. Há que se atentar, no caso particular do fundamentalismo islâmico, que não há diferença entre o plano religioso e o secular, o que faz desse movimento políticoreligioso, inevitavelmente, uma significativa força política. Questões que têm sido constantemente observadas no Oriente Médio ao longo das últimas décadas, como reiteradas ameaças à identidade étnica e à integridade sociopolítica dos povos islâmicos, têm feito com que fundamentalistas procurem conduzir as massas à restauração de valores tradicionais e culturais muçulmanos, de modo a proteger suas identidades do elemento externo, caracterizado pela pretensa submissão dos povos do Oriente Médio à inserção da cultura e dos modelos políticos em voga, principalmente, na França e na Grã-Bretanha (Cf. FERDOWS e WEBER, 1992).

Pautando-se nesse tipo de pensamento, colocam-se os fundamentalistas islâmicos em condição de preservar seus ideais tradicionais em relação à imposição de valores oriundos do exterior, uma vez que o processo de ocidentalização resultou em governos seculares ditatoriais e opressivos, distribuindo riqueza apenas a uma pequena elite, o que acabou por corroer a cultura e a tradição muçulmanas (Cf. DAVIDSON, 2003, p. 11). Percebe-se, portanto, uma direta relação entre a colonização do Oriente Médio e o ressurgimento do fundamentalismo islâmico. Nessa ótica, relacionando-se o fundamentalismo islâmico diretamente ao colonialismo, pode-se verificar que

o fundamentalismo islâmico é uma reação contra o compromisso estabelecido com a sociedade secular moderna, bem como uma expressão do desejo de manter ou redescobrir os valores essenciais da fé. (...) os muçulmanos têm sido sujeitos à divisão, ao descrédito, ao imperialismo, ao colonialismo, à tirania, à corrupção e, mais recentemente, à reocupação, tanto econômica quanto militar. $\mathrm{O}$ fundamentalismo islâmico parece querer afastar esta história desfigurada e restabelecer a submissão à palavra de Deus, seguindo os princípios mais puros ocultos no Corão (GRIEVE, 2006, p. 307-8).

Tendo os sistemas políticos ocidentais impostos às sociedades do Oriente Médio deixado de cumprir seus objetivos, alguns movimentos políticos locais passaram a colocar a religião como solução para as mazelas sociais do presente, uma vez que as alternativas ao vácuo político causado pela influência ocidental também se mostraram ineficazes ao longo das últimas décadas. Como resultado, nota-se por parte desses movimentos políticos uma repulsa pelo colonialismo, pelo neocolonialismo e pelo socialismo marxista, constituindo-se o fundamentalismo islâmico como "um canal para o 
confronto e a luta por parte das sociedades muçulmanas durante o período pós-colonial" (Cf. SILVA, 2016, p. 61-5).

Importa então conhecer a visão de mundo a partir do fundamentalismo, a qual pode envolver a questão da jihad. Segundo as explicações de Hashmi Sohail,

a visão de mundo fundamentalista parte da premissa de que a maioria das sociedades, incluindo-se nomeadamente as islâmicas, estão em um estado de jahiliyya, ou "ignorância", ligada ao estado de jahiliyya que prevaleceu na Arábia antes do advento da missão do profeta Maomé. Somente uma pequena e comprometida vanguarda de verdadeiros muçulmanos discernem o estado corrupto das questões muçulmanas e as maneiras corretas de se remediá-lo. Sua missão inicial é retirar-se mentalmente e até fisicamente, se necessário, da jahiliyya para se conscientizar dos verdadeiros valores islâmicos dentro de si próprios e de sua organização. Esta hijra, ou "voo", é o primeiro tipo de jihad que eles têm que realizar. Sob as instruções de um líder, a vanguarda muçulmana deve transformar sua jihad interior em uma jihad exterior, destinada a destituir a ordem não-islâmica e corrigir as mazelas sociais (2004, p. 261-3).

Há que se compreender o sentido do termo jihad para que fique claro de que se tratam os movimentos jihadistas. A palavra jihad, que em árabe pode ser traduzida como "esforço", encontra-se mencionado duas vezes no Corão e tornou-se bastante politizada, sendo muitas vezes invocada e erroneamente utilizada com propósitos eminentemente políticos (Cf. NYDELL, 2012, p. xix). Observa Reuven Firestone que a mensagem corânica sobre o termo em questão não é consistente, e que, quando da interpretação da palavra jihad na leitura do Corão, "os sentimentos, as ideologias, os conceitos e as atitudes expressas pelos vários versos cobrem uma vasta gama de posicionamentos" (1999, p. 47). Como coloca Margaret Nydell, o termo é objeto de interpretações conflitantes entre diferentes ideologias, podendo haver entendimentos bastante divergentes em função do viés ideológico do leitor, bem como em razão de conceitos e comportamentos a que se refere a palavra jihad em diferentes trechos do livro sagrado (Cf. FIRESTONE, 1999, p. 47).

Uma notável diferenciação quanto à interpretação do termo por parte de diferentes ramificações religiosas islâmicas é apresentada pelo xiismo, pois no entendimento desta vertente muçulmana a jihad expansionista só poderia ser conduzida por um imam descendente de Ali, opondo-se à teoria clássica expressa pelo sunismo. Ademais, tem-se que a retromencionada teoria clássica vem se defrontando atualmente com interpretações que se pautam nas ideologias modernista e fundamentalista. A 
primeira visa não simplesmente confrontar a história islâmica e os dogmas trazidos pela teoria clássica, mas propor interpretações compatíveis com o direito internacional, o que impediria entender a jihad como uma forma de subjugar os não-muçulmanos e a expandir o islamismo. Na interpretação fundamentalista, por sua vez, o "esforço" a que se refere o termo jihad é entendido como uma questão não espiritual, ou seja, dotada de manifestação física, a qual pode se traduzir em combate, se necessário, para expandir a ordem islâmica a outros povos. Contudo, nota-se que para a grande maioria dos fundamentalistas a visão da jihad como forma de expansão de sua religião não é um dos temas de maior relevância quando de discussões religiosas ou políticas (Cf. HASHMI, 2004, p. 378-9).

Dentro de um contexto religioso islâmico, o termo se refere a um esforço espiritual, virtuoso, direcionado a um objetivo louvável. Na visão de ativistas radicais, ou seja, aqueles cujo ativismo usualmente se adequa a uma interpretação fundamentalista do islã, o termo jihad adquire a conotação de "guerra santa", ou talvez mais adequadamente como "guerra justa". Dentro dessa interpretação, o termo pode ser mais bem compreendido como a guerra entre o Mundo do Islã (Dar-al-Islam) e o Mundo da Guerra (Dar-al-Harb) (Cf. SILVA, 2016, p. 56-7; HASHMI, 2004, p. 377). Tal concepção evidencia a existência de variadas traduções e formas de interpretação com relação à mensagem do livro sagrado do Islã, o que, por consequência, gera as mais diferentes formas de ensino religioso e de aplicação à vida quotidiana. A interpretação religiosa, portanto, pode gerar diferentes ideologias, como ficou evidente ao se analisarem tais tópicos acerca do fundamentalismo islâmico.

Segundo a Encyclopedia of Islam and the Muslim World (Ed. MacMillan, 2004, p. 377-9), o termo jihad é entendido pelas diferentes organizações fundamentalistas radicais como o esforço, inclusive violento, para se estabelecer a ordem islâmica. Dentre os diferentes objetivos que pode ter tal esforço encontram-se o combate à apostasia, a expansão da influência e do poder de determinada organização, a imposição da versão do islã a muçulmanos de diferentes comunidades e, de uma forma mais geral, a imposição da religião islâmica ao mundo, em havendo condições e oportunidade para tanto. Consequentemente, organizações que se utilizam do terrorismo costumam embasar suas ações violentas no conceito da jihad (Cf. HASHMI, 2004, p. 377-9). Dentro da lei islâmica, tal termo também se refere ao dever de todo muçulmano em tomar parte de uma guerra quando isso lhe for exigido. Historicamente, entretanto, o termo tem sempre se referido ao dever dos muçulmanos em melhorar a si próprios e à comunidade em que vivem (Cf. STOKES, 2009, p. 807). 
Cabe aqui notar a interpretação do termo por parte do egípcio Sayyid Qutb, dada a influência de suas colocações junto aos líderes do Estado Islâmico. Tido por muitos como um dos pensadores mais extremistas do século XX, Sayyid Qutb foi um dos principais ideólogos da Irmandade Muçulmana, organização fundamentalista islâmica criada em 1928 no Egito - personificando, na realidade, sua face mais radical. Em suas obras, Qutb argumenta que a jihad e a luta armada, e não somente a pregação pacífica, são necessárias à derrocada de governos corruptos das sociedades muçulmanas, para que se estabeleça uma ordem verdadeiramente islâmica embasada na lei peculiar a esta religião (Cf. HASHMI, 2004, p. 568-9). A influência do pensamento de Sayyid Qutb junto ao primeiro líder do Estado Islâmico fica clara, não somente quanto aos conceitos atinentes à jihad - e à consequente aplicação do jihadismo -, mas também quanto à importância atribuída ao fundamentalismo islâmico e à necessidade de ascensão de grupos militantes islâmicos. O filósofo sustentou, em sua obra Justiça Social no Islã, que tal religião possui seus próprios ensinamentos sociais, distintos daqueles propagados por valores ocidentais como o cristianismo e o comunismo, o que viria a fundamentar a união entre religião e sociedade em uma sociedade islâmica. Assim, o autor diferencia enormemente os valores relativos aos muçulmanos daqueles oriundos de sociedades ocidentais, visando um pronunciado distanciamento entre tais visões de mundo. Com relação ao Ocidente, aliás, traz o autor mais uma percepção baseada em questões históricas, ao afirmar que este "estava em queda civilizacional; o seu fim aproximava-se, tal como acontecera alguns séculos antes com o Império Romano” (Cf. SILVA, 2016, p. 105). Ainda no que tange à influência das reflexões desse filósofo junto à liderança do Estado Islâmico, deve-se notar que o egípcio estabelecia que "se uma sociedade não era governada de acordo com os princípios islâmicos autênticos, os verdadeiros muçulmanos tinham a obrigação de declarar guerra aos seus líderes opressores” (Cf. ELIAS, 1999, p. 93).

Cabe observar que os pensamentos de Qutb são resultado de uma percepção personalíssima, obtida através de suas experiências e entendimentos próprios, e não com base em colocações anteriormente registradas em obras teológico-acadêmicas. Ou seja, ele não debruçou-se sobre interpretações passadas ou já conhecidas, uma vez que esse pensador não possuía interesse nas minúcias do ensinamento teológico islâmico, atendose somente aos temas mais amplos e gerais (Cf. JACKSON, 2006, p. 203). A expressão do pensamento de Sayyid Qutb, portanto, além da questão de seu conteúdo, pode demonstrar uma dissensão entre este pensador e o ensinamento religioso e filosófico 
tradicional, isto é, colocado formalmente em bancos escolares e universitários, o que pode ter inclusive servido de motivação para que Al-Zarqawi e outros integrantes de grupos fundamentalistas não se ativessem às interpretações religiosas tradicionais. Com isto, valer-se das ideias difundidas por pensadores como Qutb - no caso deste, deixando de se manter somente no campo teórico, como ficou claro com sua suposta participação no golpe de Estado no Egito - pode ser visto como um importante fator motivador para a adoção de interpretações ideológico-religiosas incomuns, ou seja, afastando-se das principais correntes religiosas. A contrariedade com relação aos ensinamentos estabelecidos por teólogos, universitários de renome e líderes religiosos, por si só, pode ter servido como um importante componente ideológico para os grupos terroristas islâmicos ${ }^{7}$ mais recentes, dentre os quais se destaca o Estado Islâmico.

Retornando à questão específica da jihad dentro do pensamento de Qutb, este por diversas vezes deixou claro seu entendimento de que a jihad se trata de uma forma de se viabilizar o ensinamento missionário ${ }^{8}$, enfatizando que no caso de o Estado não permitir a liberdade de se exercerem tais ensinamentos, então a jihad física se justificaria, inclusive com a utilização de força bélica (Cf. JACKSON, 2006, p. 205). Fica patente, logo, que a instrumentalização do terrorismo pode ser embasada em um preceito religioso islâmico, como se vê no caso da jihad, a qual pode comportar um elemento físico, ou exterior, como colocam certos autores, na busca pela disseminação do islamismo. Assim, tem-se em uma interpretação extremista a justificação para atos violentos, incluindo-se, portanto, a prática do terrorismo por parte de certas organizações fundamentalistas, deturpando-se seu sentido histórico conforme registrado nas escrituras sagradas do Islã. Isto faz com que a denominação simplesmente por fundamentalista deixe de ser a mais adequada para se caracterizar esse tipo de organização, uma vez que a interpretação do conceito de jihad ligado à prática da violência foge à regra, colocando-se à margem das demais organizações fundamentalistas islâmicas.

\footnotetext{
${ }^{7}$ Nesta dissertação, a utilização do termo terrorismo islâmico se refere à prática do terrorismo baseado em motivações religiosas de viés ideológico ligado à religião islâmica, sendo utilizado somente quando estritamente necessário, uma vez que seu uso indiscriminado pode ter o efeito indesejado de denegrir a todos no islã e criar uma falsa associação entre o terrorismo e o islã como um todo. Tal termo, justamente por envolver vários elementos de natureza religiosa e política, é objeto de extenso debate. Nesta pesquisa, utilizar-se-á o conceito trazido por Bruce Hoffman em seu livro Inside Terrorism (2006), o qual coloca que terroristas religiosos encontram justificação moral para a prática da violência, enxergando nesta uma necessidade ao alcance dos objetivos sociais, religiosos ou políticos. A associação destes conceitos com as ideologias advindas do islamismo é discutida no subcapítulo 2.1 desta dissertação.

${ }^{8}$ Em árabe, $d a$ 'wa, cuja tradução literal é "convite". Contudo, dentro de interpretações mais específicas, como no presente caso, o termo pode ser entendido como "convite ao Islã."
} 
Já quanto ao salafismo, este deve ser entendido como uma corrente ideológica fundamentalista, estreitamente ligado ao wahhabismo surgido na península árabe no final do século XVIII. Nas palavras de Perry e Negrin (2008, p. 38), o salafismo se pauta em conceito ideológico islâmico de tradição sunita ${ }^{9}$ que pretende emular, da forma mais pura possível, tanto o pensamento quanto as práticas disseminadas pelo profeta Maomé, observados pelas primeiras gerações de muçulmanos, de forma com que se faça a lei islâmica vigorar em todas as questões da vida.

Este conceito se fez presente nas obras de Ibn Taymiyya, teólogo islâmico de origem síria do início do século XIV, que inclui o retorno da conduta dos muçulmanos e dos valores em voga nas sociedades islâmicas às suas origens, ou seja, àquilo que supostamente se praticava na época do profeta Maomé e dos quatro primeiros califas tido como os "bem-guiados" (rachidun). Ibn Taymiyya tornar-se-ia posteriormente uma das fontes do movimento salafista, o qual, por sua vez, tem estreita relação com o fundamentalismo islâmico em meio aos muçulmanos sunitas dos séculos XIX-XX (Cf. HIRO, 2002). Taymiyya, aliás, merece destaque dentre os pensadores islâmicos em razão de sua influência junto a outros filósofos e também à liderança do Estado Islâmico. George S. Rentz (2004), discorrendo acerca dos pensamentos de Taymiyya, afirma que suas reflexões incluíam profundo tradicionalismo, austeridade e rigor religioso, assim como a consequente não aceitação de inovações de qualquer tipo. Coloca que tais ideias foram consideradas bastante controversas já à sua época, inclusive devido às profundas críticas ao xiismo e ao cristianismo. Suas obras traziam ainda intensas críticas a todo e qualquer tipo de inovação religiosa, concluindo que a decadência do império islâmico de sua época estava ligada à decadência da própria religião islâmica, motivo pelo qual sua sociedade deveria tornar à pureza dos muçulmanos que da época do profeta Maomé, extirpando-se completamente as práticas ligadas ao xiismo e quaisquer outras que não se relacionassem ao sunismo (RENTZ, 2004).

\footnotetext{
${ }^{9}$ Referente ao sunismo. Origina-se do termo ahl al-sunna wa l-jama'a, em árabe, "adeptos da tradição e do consenso da comunidade.” Tradição profética do islamismo, que, basicamente, coloca que o líder de uma comunidade muçulmana deve apresentar-se como aquele detentor das melhores capacidades tanto religiosas como políticas para conduzir os fiéis no caminho do profeta Maomé, compondo cerca de 85\% dos muçulmanos no mundo. Esta condição se contrapõe ao xiismo, termo derivado de shiat ali, em árabe, "Partido de Ali". A ramificação xiita surge de cisão frente ao sunismo devido a discordâncias quanto à liderança da comunidade islâmica, a qual deveria ficar a cargo dos parentes mais próximos do profeta Maomé (Cf. LINDSEY, 2006; SILVA, 2016, p. 23-8).
} 
Mais do que reformas sociais e políticas, Taymiyya entendia que deveriam os muçulmanos realizar mudanças estruturais nos componentes espirituais internos do indivíduo, para que somente a partir daí se promovessem reformas em meio à sociedade islâmica (PEVLIN, 2004, p. 338-9). Os conceitos difundidos por Taymiyya, em síntese, visavam dois pontos primordiais. O primeiro ponto tratava-se de colocar os ensinamentos do Corão e os advindos da conduta do profeta Maomé acima de qualquer interpretação por individual. O outro ponto tratava-se de demonstrar lealdade para com os antepassados - em árabe, Salaf, termo que dá origem à ideologia salafista. Ou seja, o teólogo prega em suas obras que o poder político e a religião devem estar unidos.

Segundo Silva, para exemplificar tal entendimento, Ibn Taymiyya menciona que

sob o governo dos supracitados califas bem-guiados, o Estado Islâmico - não confundir com a organização existente atualmente - havia alcançado um nível de pureza moral e política, e esse fato deveria ser o âmago do projeto da lei islâmica. Dessa forma, reitera a convicção de que a religião só poderá ser praticada com o auxílio do Estado (SILVA, 2016, p. 83).

Tais preceitos, como se nota, objetivam ater-se a uma interpretação "pura" do Corão. O salafismo pode ser de caráter político, apolítico, ou militante na forma jihadista. Trata-se o salafismo do principal viés ideológico dentro do movimento jihadista transnacional, tendo em organizações como o Estado Islâmico do Iraque e da Síria um de seus principais expoentes (Cf. SCHMID, 2011, p. 685).

A caracterização do salafismo como um movimento social é enfatizada também por Gerges, que afirma que

o salafismo-jihadismo pode não ser um movimento de massas, mas é certamente um movimento social com redes transnacionais e uma base social em expansão, especialmente entre os jovens. Em todas as faixas etárias, a jovem parece ser atraída à mensagem do Estado Islâmico de salvação, de triunfo militar e de dominação sobre os inimigos do Islã, definidos principalmente como infiéis e hereges - particularmente a minoria xiita. Independentemente do que venha a acontecer com o Estado Islâmico, a ideologia do salafismo-jihadismo veio para ficar e é provável que conquiste mais convertidos, particularmente após o fim dos protestos da Primavera Árabe, quando as portas à mudança política pacífica tiverem sido fechadas. A narrativa do Estado Islâmico tem maior apelo devido à ausência de alternativas críveis (GERGES, 2016, p. X). 
Pode-se perceber que os principais mecanismos que levaram a tal fragmentação foram elementos construídos historicamente, como escreve Grosby (2005, p. 35). Este pesquisador, em suas análises acerca da história do Oriente Médio Islâmico, destaca que as lealdades geralmente se davam em relação à aldeia de origem e à mencionada $u m m a h^{10}$, num processo em que instituições religiosas acabaram por se tornar um elo entre esses dois entes.

Como resultado da influência de tantos e tão complexos fatores, a própria definição de cidadania nessa região também é bastante intricada. Segundo Nils Butenschøn (2015, p. 118), o conceito de cidadania para a quase totalidade dos árabes muçulmanos, mais do que advinda da relação direta com um Estado consolidado, é formado a partir das identidades culturais, políticas e sociais. Tais questões demarcam as relações entre pessoas e as comunidades às quais pertencem, além daquelas perante o Estado constituído. No entanto, essas conexões não devem ser tidas como permanentes nem como válidas para todos os indivíduos, mas sim como voláteis e inconstantes, variando de acordo com os tempos. O próprio conceito da ummah visto acima pode acabar por se alterar para um indivíduo ou para determinado grupo. Ainda nas palavras de Butenschøn, é interessante perceber, ademais, que tamanha complexidade se perfaz ao pesquisador acadêmico um grande desafio, pois entender a lógica e as dinâmicas envolvidas demandam uma ampla compreensão a respeito desses processos $(2015$, p. 118).

No que tange à sociedade e à cultura dos povos do Oriente Médio, é de grande valia se recorrer às obras de Ibn Khaldun, um dos principais filósofos da civilização árabeislâmica, autor da Al-Muqaddimah. ${ }^{11}$ Suas teorias acerca do declínio da sociedade muçulmana influenciariam acadêmicos dos séculos XIX e XX, que lhe fariam eco ao tratar de evidências quanto à necessidade de se renovar a cultura e o pensamento islâmicos. Em 1377, ao escrever sua célebre Al-Muqaddimah, o autor argumenta que as sociedades islâmicas seguiram um caminho específico rumo ao desenvolvimento e ao declínio, pelo meio do qual as tribos do deserto invadiam uma determinada sociedade, incutindo-lhe com o sentido de vitalidade a que chamou de asabiyya. Este termo designa

\footnotetext{
${ }^{10}$ Do árabe, "comunidade de crentes", por vezes traduzido como "nação". A interpretação do termo evoluiu de forma que atualmente é amplamente aceito para o mesmo o conceito de comunidade global de todos aqueles que professam a fé muçulmana (Cf. SAEED, 2004, p. 705).

${ }^{11}$ Do árabe, "o prólogo" ou "a introdução". Obra que se tornou uma das mais conhecidas e importantes obras da historiografia medieval para acadêmicos da modernidade (JAQUES, 2004, p. 335-6).
} 
o elo de sangue, ou a relação de parentesco tribal, característica da organização social árabe pré-islâmica e que perdura para além do advento do Islã. No entendimento de alguns estudiosos pode ainda ser percebido como "solidariedade coletiva". Desse modo, aquilo que o filósofo denominou por asabiyya acabou por se tornar a fundação para as relações sociais e provê os motivos básicos para o desenvolvimento cultural, intelectual e econômico. Com o passar do tempo, contudo, o sentido de solidariedade coletiva acabou por se deteriorar, seguindo-se-lhe um período de lento declínio até que o grupo se afirmasse como parte da sociedade e trouxesse consigo um novo sentido de solidariedade coletiva (JAQUES, 2004, p. 335-6). Note-se que tal sentimento coletivo, atualmente, é muito comumente traduzido como nacionalismo. O entendimento a respeito de tal sentimento se coloca de forma que a autoconsciência coletiva, no que se refere às relações sociais, está além do conceito de família, o que inclui, portanto, ligações para com vizinhos, aliados, e eventualmente até para com o Estado. Estas características do Islã, de acordo com a visão de Grosby, poderiam "ter sido um obstáculo à consolidação de países, ou até mesmo à expansão de comunidades árabes à condição de nações, durante o transcorrer de longos períodos da história do Oriente Médio islâmico" (2005, p. 96). Assim, pode-se entender que, para os povos islâmicos, o conceito de nacionalismo não está necessariamente relacionado a um determinado país ou ao seu povo, tampouco a um território definido. Deve ser relacionado, na realidade, a todos os indivíduos que compartilhem dos mesmos valores difundidos pela crença islâmica. Dessas colocações se pode depreender que o nacionalismo, dentre muitos árabes muçulmanos, trata-se de conceito muito mais amplo do que o aquele entendido por sociedades ocidentais, encontrando-se o elemento religioso como questão indissociável da identidade pessoal, em razão justamente dos vínculos constituídos pela crença islâmica.

\subsection{TERRORISMO}

Definir a utilização do termo terrorismo não é simples, pois acaba por envolver, direta ou indiretamente, temas carregados de subjetividade e altamente politizados, o que prejudica o estabelecimento de uma definição única. Tem-se que, ainda hoje, não há consenso no que diz respeito à sua definição por parte de acadêmicos, políticos e profissionais de diferentes áreas (SAGEMAN, 2008, p. 15). Atualmente, é muito comum se perceber o uso do termo violência política como substituto para 
terrorismo. Com relação a esse debate, enxerga Walter Laqueur que "as disputas sobre uma definição detalhada continuarão por muito tempo, não resultarão em consenso, e não trarão contribuição notável quanto à compreensão do terrorismo" (1977, p. 79). Entretanto, o mesmo autor entende que terrorismo pode ser definido, de forma ampla, como "o uso ilegítimo da força para se alcançar um objetivo político atingindo pessoas inocentes" (LAQUEUR, 1977). Tal definição, no entanto, acaba por empregar conceitos tão subjetivos como "legitimidade" no uso da força, e a "inocência" das vítimas.

Ao se discorrer acerca de definições quanto ao terrorismo, há que se reconhecer o trabalho de dois acadêmicos cuja originalidade tornou seus estudos pioneiros nessa temática. Inicialmente, Paul Wilkinson, com a obra Terrorism Versus Democracy: The Liberal State Response (1976), é reconhecidamente o primeiro autor a relacionar o terrorismo à democracia liberal, tema este que persiste, ainda hoje, como objeto de estudo e extensa discussão entre especialistas; e David Rapoport, o qual, em Assassination \& Terrorism (1971), foi o primeiro pesquisador a diferenciar terrorismo de outras manifestações violentas dentro do espectro político. Este último acabou por deixar um legado ainda mais notável nesta área, ao identificar no fenômeno terrorista quatro fases históricas (CRENSHAW, 2014, p. 557), ou, como preferiu o autor denominar, "as quatro ondas do terrorismo moderno" (RAPOPORT, 2004), dentre as quais se insere o terrorismo religioso, como se verá adiante.

Conquanto tenham muitos estudiosos se debruçado sobre tópicos diversos envolvendo terrorismo, ainda não há concordância plena a respeito da definição para tal. As polêmicas que devem ser enfrentadas quando dos esforços em se definir o termo terrorismo podem ser bem percebidas pela colocação do autor Philip Herbst, que menciona que

Carregando enorme carga emocional, o termo terrorismo é muitas vezes usado para definir a realidade, a fim de colocar o próprio grupo em um plano de alta moral, condenar o inimigo, reunir os membros em torno de uma causa, silêncio ou delinear um debate político, e alcançar uma grande variedade de agendas... terrorista transformou-se no mantra de nosso tempo, carregando uma carga negativa (...) Como essa palavra, tende a dividir o mundo de forma simplista entre aqueles a quem é atribuído o estigma e aqueles que se acreditam acima dele. Transmitindo um sentido de criminalidade, ilegitimidade e até mesmo de loucura, a aplicação do termo terrorista fecha as portas à discussão sobre o grupo estigmatizado ou com eles, enquanto se reforça a retidão daqueles que os rotulam como tal, justificando suas agendas e mobilizando seus reações (HERBST, 2003, p. 163-4). 
Partindo do autor de uma das obras clássicas da área de conflitos, Thomas Schelling - agraciado com o prêmio Nobel de economia em 2005 -, o mesmo estabelece como terrorismo "uma forma violenta de coerção, um processo de barganha baseado na capacidade de ferir e intimidar como substituta para a força militar convencional” (1966, p. 1-34). Já a proposta de Paulo Casaca, que enxerga que tal fenômeno se manifestou de diferentes formas ao longo da história, trata-se de termo com relação ao qual não houve claro distanciamento de outras formas de violência, como guerra não-convencional, crime em geral ou violência psicopatológica. De fato, podem-se obter na literatura de ciências como a sociologia, política e relações internacionais diferentes perspectivas a respeito do tema, gerando, consequentemente, extensas discussões (CASACA, 2017, p. 29). O pesquisador observa que a tentativa de se estabelecer qualquer critério absoluto para definir o termo em tela geralmente resta infrutífero. Em suas palavras, “o imenso esforço dispendido em se definir a ação violenta não é desproporcional à relevância de fazê-lo. Como qualquer forma de violência, o terrorismo deve ser julgado conforme sua motivação, legitimidade e proporcionalidade." Nesse sentido, Casaca mantém que terrorismo deve ser definido como algo que visa exatamente causar horror, no sentido de se paralisar, chocar ou fascinar populações que sejam alvo de suas ações (2017, p. 29). O fator psicológico envolvido na questão também é abarcado pela definição oferecida por Tore Bjorgo (2005), o qual estabelece como terrorismo "um conjunto de métodos de combate, ao invés de uma ideologia ou movimento identificável, e que envolve o uso premeditado da violência principalmente contra não-combatentes, de forma a alcançar um efeito psicológico ou medo em outros que não os alvos imediatos.”

Importante contribuição também é feita por Martha Crenshaw, que estabelece que um ato de terrorismo trata-se de uma escolha intencional perpetrada por um ator político, e que uma organização que se utiliza de tal tipo de ação atua de forma a alcançar valores coletivos, o que envolve mudanças radicais em condições sociais e políticas (1988, p. 13). Vale notar que a importância das colocações desta autora são reforçadas por Casaca, que enxerga que a única definição coerente e também cientificamente significativa de terrorismo é aquela estabelecida por Crenshaw, a qual menciona também que "o terrorismo envolve o uso ou a ameaça de mal físico de forma a alcançar efeito psicológico de dimensões desproporcionais" (2017, p. 29). Nesse sentido, tem-se como terrorismo um meio com um fim político, tendo por fito produzir mudança na postura política de determinado governo. 
Desse modo, considerando-se o caso específico de organizações não-estatais que se utilizam do terrorismo - como é o caso do Estado Islâmico, objeto de estudo neste trabalho - tal método de ação é utilizado "levando-se em conta o benefício advindo das ações terroristas, dos custos envolvidos no atentado e em suas falhas, as consequências na inação e as probabilidades de sucesso" (CRENSHAW, 1988, p. 14). Para tanto, a autora em questão estabelece perspectiva à qual chama de instrumental, na qual considera-se o método, e não a identidade ou a ideologia do autor, como determinante para que uma ação venha a ser definida como terrorismo (2011, p. 207). Convergem com essa visão as observações da pesquisadora Louise Richardson, a qual menciona que

a legitimidade, ou outra questão, dos objetivos visados por um grupo devem ser irrelevantes para a definição de um grupo como terrorista (...) assim, um terrorista não é um combatente pela liberdade e um terrorista não é um guerrilheiro. Um terrorista é um terrorista, não importando se você goste dos objetivos que ele procura alcançar, não importando se você goste ou não do governo que ele tenta mudar (RICHARDSON, 2007).

Outro estudioso da área, Audrey Cronin, ainda que reconhecendo as implicações quanto à definição do termo terrorismo em razão da evolução do conceito, e também quanto à associação do mesmo a atividades cuja compreensão é de natureza eminentemente subjetiva, percebe três características do terrorismo: possuir natureza fundamentalmente política, utilizar-se da surpresa para utilizar a violência contra alvos aparentemente indiscriminados, e estar na condição de ator não-estatal ao atingir inocentes. Avançando em suas pesquisas, Cronin define terrorismo como "a ameaça ou o uso indiscriminado de violência aleatória contra inocentes com fins políticos por parte de ator não-estatal" (2002-2003, p. 33).

O entendimento de Cronin encontra concordância com a visão de Eugênio Diniz, o qual coloca que "o termo terrorismo designa uma maneira específica de atuar politicamente; guerreia-se contra atores, grupos e organizações que eventualmente atuam daquela maneira, mas não contra a maneira em si mesma” (2010, p. 163), ainda que recordando a ausência de definição consensual sobre o que caracteriza o terrorismo. Este acadêmico traz outras importantes contribuições ao apontar para a caracterização do terrorismo como um fenômeno social, expondo que a maneira mais útil de o definir é avaliando tanto seus meios quanto seus fins. Embasa tal avaliação na premissa de que a consideração dos meios colabora com a distinção de uma ação terrorista de outras ações cujas finalidades sejam de mesma natureza; enquanto a consideração dos fins colaborará 
para com a distinção de uma ação terrorista de outras ações que empreguem os mesmos meios. De forma a complementar tais entendimentos, Diniz menciona que

Terrorismo é apenas uma parte, ou etapa, de um sequenciamento de atos e engajamentos vinculados a um propósito político último, a que ele se vincula de maneira apenas indireta, e não de maneira imediatamente perceptível. Desse modo, o terrorismo não deve ser entendido como uma estratégia propriamente dita; poderíamos chamá-lo, talvez, de um estratagema, em um sentido um pouco mais rigoroso que o de um simples ardil, mas envolvendo necessariamente a ideia de despiste e ocultação de seus objetivos imediatos - mas não dos seus objetivos últimos (...) Portanto, podemos entender terrorismo como sendo o emprego do terror contra um determinado público, cuja meta é induzir (e não compelir, nem dissuadir) em um outro público (que pode, mas que não precisa coincidir com o primeiro) um determinado comportamento cujo resultado esperado é alterar a relação de forças em favor do ator que emprega o terrorismo, permitindo-lhe no futuro alcançar seu objetivo político - qualquer que este seja (DINIZ, 2010, p. 170-2).

Finalmente, coloca-se a visão de Fernando Reinares, o qual elenca, tendo por objetivo o escopo acadêmico relativo ao tema, três diferentes pontos a serem considerados para que se defina terrorismo. O pesquisador estabelece, inicialmente, que o terrorismo se trata de um ato de violência que produz amplas e desproporcionais reações como medo e ansiedade, as quais provavelmente influenciarão comportamentos e providências em sua decorrência. Um segundo ponto é o entendimento de que a violência é sistêmica e deveras imprevisível, sendo comumente direcionada contra alvos carregados de valores simbólicos ou significados valorosos. Por derradeiro, identifica o autor que a violência produzida transmite mensagens e ameaças com o fito de se ganhar controle social e comunicar esta condição (REINARES, 2005, p. 120).

Este, por se ater mormente à metodologia utilizada por um grupo para alcançar seus objetivos, permite que o pesquisador se distancie, em grande medida, de questões políticas, religiosas e sociais, por exemplo, as quais acabam muitas vezes por enviesar estudos e análises. Essa condição, portanto, pode ser considerada de grande valia para pesquisas e estudos de natureza acadêmica, mormente no que diz respeito à classificação de terrorismo, pois permite uma análise concêntrica em relação ao objeto de estudo, despindo-se da necessidade de se atender a conceitos políticos e religiosos, para se citarem somente alguns dentre aqueles que são largamente utilizados na literatura relacionada tema. Assim sendo, ao se utilizar o termo no presente trabalho, deve-se entender o termo terrorismo conforme as considerações aqui feitas, compreendendo-se 
que diferentes autores se utilizam de variadas definições ao expor seus estudos. Dessa maneira, aproveitam-se os ensinamentos, as perspectivas e as considerações apresentadas por diferentes acadêmicos com relação aos temas de interesse a esta investigação, sem se deixar prejudicar a pesquisa devido a entendimentos peculiares ou visões específicas por parte de determinados autores.

Entendendo-se o terrorismo, portanto, como um meio e não como a natureza de determinada organização, estatal ou não. Relacionando tal entendimento com o objeto deste estudo, nota-se que tal tipo de definição é compatível com o que se verifica quanto à atuação do Estado Islâmico, como se discutirá mais à frente. Isto posto, prossegue-se com a discussão de conceitos a serem utilizados na presente pesquisa.

\subsubsection{Terrorismo Islâmico}

Trata-se de um termo que tem suas origens em teorias e pressupostos existentes em estudos e pesquisas acerca do terrorismo propriamente dito, mas que absorve conceitos advindos de questões ideológico-religiosas, os quais muitas vezes podem levar a percepções incorretas acerca da natureza ou do real objetivo de determinadas organizações e atores não-estatais. É perceptível que tal termo possa trazer consigo elementos narrativos e concepções presentes na literatura acadêmica que seguem a tradição orientalista acerca do Oriente Médio e da cultura árabe. O orientalismo, saliente-se, trata-se de sistema de estudo desenvolvido em universidades ocidentais mormente durante os séculos XIX e XX. Neste sistema, a exemplo do que cita Qamar Huda (2004, p. 515), consideram-se o Ocidente e o Oriente como distintos, com base em considerações ontológicas e epistemológicas, colocando-se o Oriente como uma contraposição à cultura ocidental, apontando-se em grande medida considerações negativas da "cultura árabe" em relação à "cultura ocidental." Tais pressupostos podem trazer, há que se convir, questões e considerações que por vezes não são compartilhados por muitos acadêmicos, em razão de diversos elementos historiográficos e políticos, por exemplo. Essa condição exige de pesquisadores do tema, por óbvio, que se atente para determinadas nuances oriundas de suas concepções, de forma a não se prejudicarem os objetivos de suas investigações, não se desconsiderando completamente as visões típicas de estudiosos que se utilizem de outros sistemas de estudo. 
Quando da utilização do termo terrorismo islâmico podem ser observados também, de certa maneira, alguns estereótipos culturais relativos a sociedades árabes ou islâmicas, como aqueles ligados à violência, ao extremismo e ao fanatismo, por exemplo (Cf. JACKSON, 2007, p. 398-400). Aparentemente, o termo em questão advém dos estudos relacionados ao terrorismo religioso, assunto sobre o qual David Rapoport escreveu em artigo acadêmico denominado Fear and Trembling: Terrorism in Three Religious Traditions (1984). Rapoport também elaborou uma sistematização na qual divide o "terrorismo moderno" segundo sua motivação política, em quatro ondas: 1) anarquista; 2) anticolonial; 3) marxista-socialista; 4) religioso (RAPPOPORT, 2004, p. 47). As teorias do autor em questão acabaram por fomentar extensos debates acerca do terrorismo, vez que suas teorias abarcam elementos sociais, políticos e culturais que vêm a demandar distintas abordagens acadêmicas (Cf. WALLS, 2017, p. v, 49).

Independentemente da sistematização estabelecida por Rapoport quanto às fases do terrorismo na era moderna, há elementos de suas pesquisas que são importantes para o estudo do desenvolvimento e da evolução dos grupos terroristas no Oriente Médio. Dentre os grupos de interesse para o presente estudo encontram os grupos sionistas atuantes na Palestina nas décadas de 1930 e 1940, notadamente o Irgun e o Lehi (chamado de "Bando Stern" pelos ingleses), os quais buscavam a formação de um estado judaico (Cf. BARR, 2011, p. 10). Note-se que no caso do Irgun (Organização Militar Nacional), um de seus líderes, Menachem Begin, após a formação do Estado de Israel, tornou-se o primeiro-ministro daquele país (HENDERSON, 2004, p. 63), fator este que pode ser apontado como motivador para a formação de diversos grupos terroristas no Oriente Médio nas últimas décadas, uma vez que este caso pôde ser visto como um indicativo do relativo sucesso da luta armada com o uso do terrorismo naquela região. Note-se que o então líder do Irgun, o qual planejou e executou ataques armados contra civis, não só logrou contribuir para com a formação do Estado de Israel - objetivo máximo de sua organização - como depois tornou-se figura pública reconhecida pela comunidade internacional (FELTON, 2008, p. 57). Os métodos utilizados pelo Irgun em suas campanhas deixaram legado, pois o grupo acabou por estabelecer um modelo que passou a ser posteriormente copiado e aplicado por diferentes organizações que não viam problemas em se utilizarem de atentados terroristas (HOFFMAN, 2006, p. 46).

O período mais recente tratado na pesquisa de Rappoport cita como organização mais relevante a Al-Qaeda (RAPOPORT, 2004), a qual figura como exemplo de grupo cuja atuação se pauta mormente em razão das convicções ideológico-religiosas 
de seus líderes. Dada a relevância da organização Al-Qaeda - cuja denominação significa, em árabe, "a Base", ou "o Fundamento" -, é necessário conhecer que a mesma se trata de uma organização fundamentalista islâmica, a qual, entretanto, deve ser melhor definida como salafista-jihadista em razão da ideologia que norteia suas ações. Esta condição a afasta das organizações fundamentalistas islâmicas que não façam o uso da violência com base em interpretação extremista da jihad. Há que se esclarecer que se trata de organização internacional fundada pelo saudita Osama Bin Laden no final da década de 1980, a qual possuía por finalidade, inicialmente, combater a invasão soviética no Afeganistão. Seu objetivo, após a retirada soviética, passou a ser a união de todos os muçulmanos para que se estabelecesse um governo regulado por califas islâmicos, que liderariam sua comunidade conforme a sharia ${ }^{12}$. Esta organização, que prega a força como único meio para se chegar ao objetivo proposto, opera conjuntamente com outros grupos salafistas-jihadistas. Em meio à evolução de questões geopolíticas mudou também seus objetivos, passando a ter por escopo derrubar regimes considerados nãoislâmicos para eliminar a influência ocidental dos países muçulmanos e então abolir todas as fronteiras entre esses países (COMBS e SLANN, 2007, p. 262).

Percebe-se que em certos casos a forma de atuação de determinadas organizações acaba por deixar um legado a grupos de gerações vindouras, as quais acabam por conseguir aplicar determinados modelos, dado seu sucesso político, no contexto histórico em que se inserem. Ou seja, tem-se que em alguns casos os métodos terroristas subsistem no tempo, provando-se eficazes mesmo em diferentes contextos históricos e com relação a distintos objetivos políticos. Mesmo que nem sempre as lideranças das organizações estudadas definam seus objetivos como políticos, é fato que o eventual sucesso de suas campanhas acabará por ensejar em ganhos políticos de algum tipo. Pode-se constatar, portanto, um legado deixado por certas organizações que fizeram uso instrumental do terrorismo, ainda que em distintos contextos políticos e sociais, a suas congêneres de ulteriores fases históricas.

De fato, mediante uma observação criteriosa não só da evolução do terrorismo moderno mas também do modus operandi das organizações mais comuns no presente momento, vê-se que o "terrorismo religioso" de cunho islâmico, tendo por principais

\footnotetext{
${ }^{12}$ Do árabe, "caminho". Designa comumente a lei islâmica, referindo-se ao código de conduta ética e moral derivado do Corão e da Sunna. Pode também ser entendida sua tradução, numa visão mais ampla, como "caminho da fé" (Cf. BROCKOPP, 2004, p. 618).
} 
expoentes a Al-Qaeda e o Estado Islâmico - os quais se tornaram referência dentre as organizações salafistas-jihadistas - a ocorrência de atentados suicidas têm sido sua maior marca, ainda que já tenham se utilizado de diferentes maneiras de disseminar a violência. Além disso, o uso de explosivos acabou por se tornar uma espécie de marca registrada das organizações do tipo (Cf. SPAAIJ, 2010, p. 866). Tal tipo de atuação, tamanho o impacto psicológico e o apelo de cunho ideológico-religioso que possui, acabou por fazer mais do que simplesmente caracterizar esses grupos quanto à sua forma de atuação. Tais atos têm servido de inspiração para outros grupos e até para indivíduos que agem isoladamente, como já registrado em diferentes países (denominados comumente de "lobos solitários""). Esses atributos, efetivamente, têm caracterizado as organizações terroristas neste século XXI, as quais agem preponderantemente em razão de questões ideológicas advindas de interpretações extremistas de preceitos religiosos, condições estas que vêm a confirmar as teorias de Rapoport.

Daquilo que foi analisado até aqui, pode-se determinar a utilização do termo terrorismo para aquilo que se refere à forma de atuação de uma organização, ou seja, tendo no terrorismo uma forma instrumental, um meio de se buscarem seus objetivos, independentemente da natureza destes. Ao se denominar uma organização como terrorista, refere-se, portanto, à sua forma de atuação e aos meios que emprega visando seus objetivos. A instrumentalização da violência por meio do terrorismo é o escopo quando se designa certo grupo ou organização como sendo terrorista. Reforça-se, neste ponto, de que não se atém tal atributo à natureza primordial da organização nem aos seus objetivos.

Pode-se ver como terrorismo islâmico, ademais, a utilização instrumental do terror por parte de organizações cuja natureza se pautem em preceitos ideológicoreligiosos, ou seja, que definam sua razão de ser e seus objetivos em questões advindas de uma orientação ideológica específica pertencente ao islamismo. Cumpre salientar, entretanto, que apesar de determinadas organizações se definirem como tal - seja como fundamentalistas islâmicas, salafistas ou jihadistas - tal acepção não significará, na realidade, que seus objetivos finais realmente se caracterizem dessa forma. Como se

${ }^{13}$ Indivíduos que perpetram ataques terroristas utilizando-se dos mesmos métodos difundidos por organizações terroristas, mas que não pertencem a qualquer grupo, sendo somente simpatizantes da causa ou do propósito de tais grupos. Distinguem-se de assassinos comuns, considerando-se a literatura a respeito, por serem suas ações motivadas por questões ideológicas, políticas ou religiosas, e não por terem alguma motivação pessoal contra suas vítimas (Cf. SPAAIJ, 2010, p. 857). 
analisará mais adiante, a imagem passada por determinada organização, a simbologia por ela utilizada e a retórica difundida por sua liderança não comunicam necessariamente sua verdadeira ideologia ou seus objetivos. Assim sendo, ao se classificar como "terrorista islâmica" a determinada organização, deve-se entender tal denominação como simples menção ao embasamento para o uso instrumental da violência, ou seja, da perpetração de atos terroristas com base em supostos preceitos religiosos islâmicos, como, por exemplo, a interpretação extremista do conceito de jihad, como analisado anteriormente.

No que concerne às organizações que se valeram da instrumentalização do terrorismo nas últimas décadas, observam Combs e Slann que, na década de 1980, os grupos terroristas de cunho político foram gradativamente abandonando a luta armada e passaram a tiveram acentuada diminuição de suas atividades, seja devido à reação da comunidade internacional como ao enfraquecimento de seus financiadores. Nesse período, os grupos terroristas cuja motivação se pautava principalmente em aspectos ideológico-religiosos tornaram-se muito mais ativos e violentos. Em pouco tempo, devido à evolução da política internacional, ao alto nível de violência e também à magnitude de suas ações, os grupos terroristas oriundos de países islâmicos tornaram-se os mais relevantes e ativos dentre os outros grupos desse tipo (2007, p. xiii). É justamente a essa altura que surge a Al-Qaeda, a primeira organização que possuía como sua principal característica a motivação ideológico-religiosa. A partir de então, um amplo movimento internacional salafista-jihadista, fundamentado em fatwas $^{14}$ oriundos de estudiosos militantes islâmicos de vários países, tornou-se questão de segurança internacional, dada a relevância da atuação de tais organizações não-estatais para a geopolítica (Cf. WIKTOROWICZ, 2001, p. 18-19). Tal organização é de grande relevância para que se estude o Estado Islâmico, tanto no que diz respeito às suas principais características quanto à sua forma de atuação.

Prosseguindo com o incremento da influência ideológico-religiosa junto às organizações terroristas, assinala Bruce Hoffman que a Al-Qaeda foi responsável, em grande parte, pela influência junto a outras organizações terroristas da atualidade ao inserir questões dessa natureza como a mais relevante dentre suas características (2006, p. 82). Esse pesquisador, aliás, estudioso do terrorismo e com especial atenção àquele de

\footnotetext{
${ }^{14}$ Considerações religiosas de caráter jurisprudencial, que visam indicar à comunidade islâmica preceitos acerca da conduta a ser observada nos mais diversos aspectos da vida quotidiana. Normalmente, refere-se a questões específicas (PETERSON, 2004, p. 255).
} 
cunho religioso, faz importantes observações no que diz respeito à conexão entre terrorismo e religião, mencionando que

\begin{abstract}
para o terrorista religioso, a violência é antes de tudo um ato sacramental ou dever divino executado em resposta direta a alguma ordem ou exigência teológica. O terrorismo assume, assim, uma dimensão transcendental, e os seus perpetradores, por conseguinte, muitas vezes ignoram as restrições políticas, morais ou práticas que possam afetar outros terroristas. (...) os terroristas religiosos procuram frequentemente a eliminação de inimigos definidos por categorias e consideram, da mesma forma, a violência em grande escala não só moralmente justificada mas também como meios necessários para a consecução de seus objetivos (HOFFMAN, 2006, p. 88).
\end{abstract}

Além dessas características comportamentais, é importante conhecer o papel da religião dentro das organizações, já que esta acaba, em grande medida, por definir tais organizações. Ao se observarem as características acima, nota-se que a religião acaba por estabelecer condições comportamentais que diferenciam seus integrantes de outros grupos que também pratiquem atos de violência com o fito de se atingirem fins políticos.

As diferentes organizações terroristas, independentemente de suas características e origens, vieram a se multiplicar em razão dos sucessos - ainda que nem sempre completos - de suas ações. O resultado disso vai além da influência quanto à criação de novos grupos, mas também quanto à renovação e à evolução dos métodos dos grupos já em atividade. Com o desígnio de se perceber sua evolução sistêmica, vale conhecer as observações de Pedro Ferreira, que nota que

as organizações terroristas passaram a ter capacidade para executar ataques em vários países e a receber apoio direto e indireto de vários Estados. As suas estruturas de comando e controle e os seus campos de treino passaram a funcionar em vários países. Por outro lado, graças ao desenvolvimento moderno das comunicações, o terrorismo internacionalizou-se, reproduzindo-se midiaticamente e tornando-se num modo específico de comunicação. Com efeito, a relação "custobenefício" criada pelos terroristas relativamente aos meios de execução e o impacto que o terrorismo tem na sociedade civil fazem deste uma arma de dissuasão (Cf. FERREIRA, 2006, apud SILVA, 2016, p. 128)

Considerando-se os elementos discutidos até aqui, nota-se que o surgimento de organizações que lançam mão de métodos terroristas para alcançar seus fins políticos podem atender a diferentes circunstâncias, de acordo com o momento histórico e com a conjuntura sócio-política experimentada pelo grupo. Ainda são importantes os elementos 
culturais, religiosos e econômicos vivenciados por seus integrantes antes ou durante suas atividades na organização. Assim sendo, avancemos de forma a analisar como se inserem tais assuntos no escopo desta pesquisa. Dada a necessidade de se avaliar o surgimento do Estado Islâmico, há que se ater, primeiramente, ao estudo da situação do Iraque atual, onde, conforme parcela significativa de acadêmicos, a intervenção anglo-americana de 2003 no país desencadeou o surgimento de grupos insurgentes que se tornariam o embrião do Estado Islâmico do Iraque. Posteriormente, então, se realizará exame quanto à conjuntura atual da Síria, cuja guerra civil iniciada em 2011 tem sido apontada pela Academia como intimamente relacionada ao surgimento de grupos insurgentes que viriam a compor o Estado Islâmico do Iraque e da Síria. Destarte, passam-se a estudar isoladamente a conjuntura desses dois importantes países do Oriente Médio, de maneira a melhor fundamentar o estudo do objeto desta pesquisa. 


\section{O IRAQUE CONTEMPORÂNEO}

\subsection{QUESTÕES DE ECONOMIA, POLÍTICA E SOCIEDADE}

Para que se possa compreender o processo histórico do surgimento do Estado Islâmico no Iraque, propõe-se aqui uma breve análise de algumas das principais questões econômicas, sociais, e políticas do país no período de Saddam Hussein.

Em um Estado extremamente dependente do petróleo, o presidente iraquiano Saddam Hussein, no poder desde 1979, garantia o controle de praticamente todas as comunicações, das forças armadas e da economia nacional. No entanto, o que garantia ao partido Baath ${ }^{15}$ o poder totalitário do Estado e de suas instituições não era somente sua condição de principal empregador público, mas, principalmente, o fato de ser o detentor do setor petrolífero e, consequentemente, o único produtor desse insumo. Com a alta do preço do petróleo a partir de 1974, o Estado iraquiano tornou-se economicamente independente da capacidade produtiva de sua própria sociedade (Cf. GHAREEB, 2004, p. 65). Os lucros proporcionados pelo petróleo permitiram ao governo estabelecer relações de clientelismo diretamente com líderes tribais distribuídos por seu território, o que viria a trazer consequências sociais e políticas ao povo iraquiano, com grandes consequências à economia local (Cf. ISMAEL e ISMAEL, 2015, p. 15-6). A questão tribal se desponta, portanto, como um importante fator de manutenção do poder e de negociação política em meio à sociedade iraquiana.

Paralelamente, as questões geopolíticas que naturalmente interferiam na economia doméstica - a qual se sustentava em grande parte nas mencionadas relações tribais - e a influência de questões nacionalistas para a política regional do partido Baath fizeram com que o governo passasse a incrementar de maneira intensiva seus gastos militares a partir daquela época. Tais circunstâncias desembocaram, em 1980, na invasão iraquiana ao Irã, iniciando-se a guerra Irã-Iraque, que se arrastaria por quase oito anos.

\footnotetext{
15 Partido político pan-árabe (também descrito como Al-Ba'th), fundado na Síria em 1944, expandindo-se posteriormente para o Iraque. Seus fundamentos são o nacional-socialismo, a independência dos poderes estrangeiros e o pan-arabismo. Os dirigentes do partido normalmente colocavam sua ideologia como o principal instrumento para se chegar a uma unidade árabe no Oriente Médio. Em 2003, Saddam Hussein era ao mesmo tempo presidente do partido e do governo iraquiano (Cf. SIMON e SLUGLETT, 2004, p. 413).
} 
Esse conflito acabou por desgastar demais as finanças do governo de Saddam Hussein, restando à economia iraquiana grandes prejuízos, que viriam a se agravar ainda mais com as seguidas quedas no preço do petróleo no final da década de oitenta. Por conseguinte, o Iraque afundou-se em grave crise socioeconômica, cuja solução por parte do governo foi uma nova empreitada militar, em 1990. Desta o alvo seria o Kuwait, tendo o governo iraquiano por finalidade controlar os campos petrolíferos do país vizinho, visando assim reequilibrar a economia do país (Cf. ISMAEL e ISMAEL, 2015, p. 17). Contudo, tendo as forças de diversos países, encabeçados pelos Estados Unidos, auxiliado militarmente o governo do Kuwait, Saddam Hussein teve de se retirar após esmagadora derrota. O resultado dessa nova empreitada militar foi a destruição completa da infraestrutura civil iraquiana e o estabelecimento de sanções internacionais em desfavor do Iraque. A economia deste país, por fim, veio a se agravar de tal forma que se instalou no país uma complexa crise humanitária, a qual legaria à sua população a mais crítica condição socioeconômica desde a chegada de Saddam Hussein ao poder (Cf. DEMANT, 2004). Concomitantemente, o governo Baath viu-se isolado política e economicamente perante a comunidade internacional. Este panorama, acentuadamente devido à derrocada da economia, acabou por aumentar as diferenças entre o governo iraquiano e as lideranças de outros estados árabes, além de ter motivado um pronunciado crescimento nos sentimentos antiocidentais dentre a maioria da população iraquiana (Cf. ISMAEL e ISMAEL, 2004, p. 126-165).

No que diz respeito às instituições financeiras do país, relevantes para a condução das políticas econômicas praticadas pelo regime de então, as mesmas foram nacionalizadas em 1964. A moeda iraquiana, o dinar, é emitida pelo Banco Central do Iraque, fundado em 1947 e conhecido por ter sido um dos mais antigos bancos centrais do Oriente Médio. Por volta de 2004, tendo o Iraque passado por longos períodos de isolamento comercial e, principalmente, enfrentado três conflitos militares de grandes dimensões - as retromencionadas Guerra Irã-Iraque na década de 1980, a Guerra do Golfo em 1990 e a Guerra do Iraque em 2003 -, a economia do país se encontrava em situação de enorme desordem, o que acabou por arrastar o Iraque a uma grande dívida nacional. A inflação originada com o fim da Guerra do Golfo havia sido somente o início dos graves problemas econômicos que começavam a assolar o Iraque, já que os bancos iraquianos se encontravam impossibilitados de operar no exterior, principalmente devido ao embargo imposto pela Organização das Nações Unidas. Em decorrência disso, as instituições financeiras do país, incluindo-se suas contas e os mais variados recursos, acabaram por 
ser congelados no intuito de se garantir que fossem pagas as dívidas que se acumulavam havia anos. A comunidade internacional, atenta à deterioração econômica no país, passou a supervisionar todas e quaisquer atividades financeiras e econômicas advindas da exportação de petróleo iraquiano, atuando de forma a se proporcionarem melhorias econômico-sociais. Destarte, a comunidade internacional, agindo como uma garantidora de fundos, teve que trabalhar para proporcionar às instituições financeiras iraquianas as condições para voltar a atuar internacionalmente. Essa condição visava melhorar as condições sociais da população iraquiana, procurando alavancar, principalmente, a oferta de alimentos. Entretanto, a situação econômica era tão crítica que os Estados Unidos, ainda durante a Guerra do Iraque, tiveram de divisar diferentes modos de refinanciar ou até de perdoar parcelas da dívida iraquiana para com outros Estados (Cf. ETHEREDGE, 2011, p. 43).

Percebe-se, assim, que os graves problemas econômicos do Iraque colocaram o país em condição de ser considerado como um estado falido, ou seja, as parcas condições sociais e políticas mantidas pelo governo e sua população fizeram com que as instituições iraquianas se tornassem incapazes de se sustentar de forma eficaz. Para melhor se entender tal conceito, mormente em meio à conjuntura histórica em que se pode enquadrar o Oriente Médio atual, tem-se que

\begin{abstract}
quando o colonialismo terminou, muitos governos que se seguiram não conseguiram fornecer serviços mínimos aos cidadãos. Uma combinação tóxica de conflitos étnicos, corrupção, pobreza, superpopulação e estresse ambiental causou a colapso das instituições estatais nesses países, resultando em "estados falidos". Os governos dos estados falidos são considerados ilegítimos pelos cidadãos, são incapazes de exercer autoridade sobre o território do estado, não conseguem fornecer segurança ou serviços essenciais aos cidadãos, e geralmente enfrentam oponentes armados (MANSBACH e TAYLOR, 2012, p. 157)
\end{abstract}

Dentro dessa perspectiva se pode denotar a relação entre a falência de um Estado e a fase pós-colonial de sua história. Ainda que as consequências do colonialismo não possam ser tidas como o único motivo pelo qual um Estado pós-colonial seja levado a tais condições, é importante se observar tal correlação, uma vez que o Iraque se enquadra nessa perspectiva. A esta, aliás, se alinha o entendimento de Christian Parenti, o qual menciona que estados falidos se tratam de territórios em que

o colapso seja a norma, ainda que a governança e a administração não estejam totalmente ausentes. Estes existem, mas numa forma espectral. 
É como se o estado falido houvesse revertido a antigos métodos de tributação e dominação e reciprocidade. Como a falência do Estado é relativa, na maioria dos denominados estados falidos o governo é uma ruína semifuncional (PARENTI, 2001).

Cabe conhecer que o instituto Fundo para a Paz relatou, em seu Índice de Estados Falidos de 2007, que o Iraque se tratava do segundo país em piores condições naquele ano, dentre 178 pesquisados (FUND FOR PEACE, 2007), o que reforça a condição do Iraque dentro desta avaliação. No período que se sucedeu à Guerra do Iraque, portanto, repara-se que as instituições responsáveis pela saúde, educação e transportes além das já discutidas áreas de defesa e de energia - não mais possuíam meios para oferecer serviços adequados aos seus cidadãos. As consequências dessa situação acabaram por colocar a população iraquiana em condições de vida similares àquelas da época pré-industrial. Consequentemente, as relações sociais dentre os iraquianos voltaram a se pautar, em grande medida, nas ligações étnico-religiosas e sectárias para se estabelecerem relações de poder, as quais também se tornaram, como outrora, questões fundamentais de segurança do indivíduo e de sua comunidade. Constituindo-se o Iraque em estado falido, encontrava-se o mesmo à mercê da constante volatilidade da geopolítica. Incapaz de se sustentar por si só em caso de quaisquer interferências externas, o Iraque apresentava-se como uma peça frágil no tabuleiro político do Oriente Médio. Diferentemente das ocasiões anteriores em que tivera de lidar com conflitos internacionais, desta vez não seria o Iraque que daria o primeiro passo para que eclodisse um conflito armado. Logo o Iraque sofreria as consequências das decisões políticoeconômicas de Saddam Hussein que lançaram o país de volta às condições experimentadas na era pré-industrial (Cf. ISMAEL e ISMAEL, 2004, p. 20; 204).

\subsection{RELIGIÃO NO IRAQUE}

A questão religiosa também deve ser pontuada ao se estudar a situação do Iraque, uma vez que esta interfere sobremaneira na política nacional e nas disputas pelo poder. Assim, deve-se pontuar que a população iraquiana é composta majoritariamente por muçulmanos xiitas, assim como seu vizinho Irã, o qual clama ser o principal representante do xiismo no mundo islâmico. Entretanto, a população iraquiana apresenta 
uma situação particular ao possuir uma proporção entre xiitas e sunitas bastante equilibrada. Dentre sua população muçulmana - a qual consiste em $95 \%$ da população nacional - cerca de $60 \%$ são xiitas, sendo que a minoria sunita inclui também a população curda em quase sua totalidade. Tal distribuição dentre a população caracteriza o país como o Estado com a divisão religiosa mais equilibrada dentre os países islâmicos (Cf. AL-QAZZAZ, 2004, p. 1130). Enquanto praticamente todos os xiitas iraquianos são árabes, a população sunita engloba tanto a etnia árabe quanto a curda. Apesar dessa condição, desde a fundação do estado iraquiano em 1920 o governo central iraquiano foi composto por sunitas, o que acabou por desequilibrar a distribuição de poder político no país. O mais notório dos presidentes iraquianos, Saddam Hussein, que se manteve no poder entre 1979 e 2003 - quando da intervenção norte americana - utilizou-se de repressão e de perseguições dentre cidadãos xiitas durante seu governo como parte de sua estratégia para administrar o poder entre as diferentes comunidades no Iraque (Cf. ETHEREDGE, 2011, p. 20).

No Iraque o fundamentalismo sunita nunca foi muito acentuado, não tendo se constituído em problema político para o regime baathista de Saddam Hussein. Este sempre oprimiu com severidade qualquer eventual oposição política dentro do país, tendo as únicas ameaças ao regime se constituído de curdos e de islamistas. Entretanto, a cisão existente entre a discriminada maioria xiita e a minoria sunita - esta privilegiada pelo governo, já que o próprio presidente era representante do sunismo - inviabilizou qualquer tentativa de expressão islamista que se fizesse notar no Iraque. Por conseguinte, a oposição se concentrou entre fundamentalistas xiitas, cujos representantes viriam a ser os primeiros a agir quando da queda do regime de Hussein (Cf. DEMANT, 2004, p. 219).

As divisões sectárias existentes no Iraque e os diversos problemas daí originados vieram a se traduzir em disputas políticas de forma bastante violenta. No caso da parcela sunita, apesar de se tratar de minoria, esta usufruiu por décadas das melhores prerrogativas junto ao governo graças ao seu representante como presidente. É importante ressaltar que este promovia durante seu governo o genocídio curdo e também a execução de integrantes de partidos xiitas, visando tornar a população iraquiana cada vez mais homogênea, o que lhe garantiria melhor governabilidade (Cf. DEMANT, 2004). 
Tendo o governo norte-americano declarado sua "guerra ao terror" após os ataques de 11 de setembro de 2001 nos Estados Unidos, este país passaria a se envolver em conflitos em escala global de forma a intervir em todo e qualquer Estado cujo governo alegadamente apoiasse de alguma forma organizações que se utilizassem do terrorismo contra os Estados Unidos. Isto levou, logo em 2003, a uma intervenção militar no Iraque, que contou com o apoio do governo britânico, em função da alegação de que o regime de Saddam Hussein possuiria e produziria armas químicas e de destruição maciça, o que nunca restou provado (Cf. POLK, 2006, p. 200-1). Segundo os relatórios do sueco Hans Blix, inspetor-chefe da Comissão das Nações Unidas para Monitoramento, Verificação e Inspeção, entidade responsável pela inspeção de conformidade do Iraque com relação a armas de destruição em massa, "inspetores visitaram quase setenta locais no país sem terem encontrado quaisquer evidências de inconformidades do Iraque que pudessem justificar uma invasão" (Cf. ISMAEL e ISMAEL, 2015, p. 53). Como nota William Polk (2006, p. 174), a principal motivação trazida pelo governo norte-americano para dar início à intervenção, contudo, foi de que o Estado iraquiano manteria ligações com a organização salafista-jihadista Al-Qaeda. Ou seja, tanto os ideais desta organização quanto sua atuação terrorista já eram vistos à época como uma ameaça tanto aos Estados Unidos quanto a outros países ocidentais, principalmente os aliados dos norteamericanos. O fato de a Al-Qaeda ser tida, na época, como uma das principais ameaças aos Estados Unidos - resultado da série de atentados propagados contra norte-americanos em diversos países e, finalmente, em solo estadunidense - e a necessidade de manter a hegemonia política e militar mundialmente explicam, aparentemente, o empenho por parte da cúpula do governo norte-americano em depor o governo de Saddam Hussein para que fosse instalado um regime pró-americano naquele país.

A ação militar em tela, que segundo seus organizadores se constituiria numa intervenção humanitária, valia-se também do conceito de guerra preventiva. Contudo, após a deposição do governo iraquiano de Saddam Hussein, as forças estrangeiras não deixaram o país. O resultado da intervenção foi a ruína das estruturas sociais e estatais do Iraque em decorrência das ações militares, em meio a que os norte-americanos instituíram um novo governo provisório, visando impedir que se perpetuassem as organizações políticas e sociais oriundas do antigo governo. Ademais, objetivava-se construir uma estrutura governamental conforme os princípios ocidentais, viáveis econômica e geopoliticamente à Grã-Bretanha e aos Estados Unidos (Cf. RICKS, 2006, p. 61). Um 
dos principais problemas causados pela Guerra do Iraque, segundo Keegan (2004, p. 91), foi que este país se tornou ainda mais dividido do que antes. $\mathrm{O}$ autor coloca que tal conflito serviu para que o mundo árabe confirmasse que norte-americanos e europeus estavam preparados para usar seu poderio militar para mantê-los subordinados a seus interesses. Estas colocações, principalmente acerca da preocupação em se instituir um novo governo - o que decerto seria constituído conforme os interesses dos governos que encabeçavam a intervenção - permitem perceber certa mentalidade colonialista por parte dos líderes britânico e americano. Muito provavelmente os cidadãos e antigos funcionários do governo derrubado viam a ação ocidental que se iniciava no Iraque a partir dessa perspectiva, até porque um cenário análogo havia sido observado algumas décadas antes. Decerto, grande parcela da população iraquiana acabava por enxergar na campanha das forças da coalizão liderada pelos EUA uma renovação das políticas colonialistas experimentadas pelas gerações anteriores, cujas consequências ainda se fazem sentir em meio à sua sociedade de diversas maneiras.

Os arranjos políticos realizados pelos representantes dos governos norteamericano e britânico logo após a intervenção viriam a promover o início de graves conflitos sectários. O Conselho de Governo iraquiano estava dominado pelo chamado Supremo Conselho Islâmico do Iraque, mas a influência estrangeira para o estabelecimento de um governo não foi bem aceita por muitos grupos iraquianos. Em decorrência disso, surgiu nessa mesma época um grupo insurgente que rivalizava com o conselho estabelecido pelas forças estrangeiras, denominado Jaysh al-Mahdi ${ }^{16}$, o qual chegou a declarar a constituição de seu próprio Estado em setembro de 2003, tendo por capital a cidade de Najaf. Já se notava, portanto, desde os primórdios da insurgência iraquiana um importante movimento de caráter político, já que o Jaysh al-Mahdi declarara total inobservância às imposições norte-americanas no país, não reconhecendo sequer que as comunidades que integravam tal grupo pertencessem àquilo que se denominava comumente por Iraque (Cf. HASHIM, 2012, p. 175). Percebe-se na natureza da ação desse grupo insurgente um viés marcadamente nacionalista, o que pode ser explicado por uma perspectiva colonialista face às intenções norte-americanas naquele território. Esta condição se acentua ao se perceber que o regime alegadamente democrático recentemente

\footnotetext{
${ }^{16}$ Do árabe "Exército de Redentores", grupo paramilitar iraquiano de origem xiita formado em 2003 logo após o colapso do governo de Saddam Hussein. Pertence ao movimento político denominado "Movimento Sadr", liderado pelo clérigo Muqtada al-Sadr, filho de Muhammad Sadiq al-Sadr, crítico proeminente do partido Baath e da pessoa de Saddam Hussein, assassinado numa emboscada em 1999 (Cf. ANZALONE, 2010, p. 761-2).
} 
instituído procuraria trazer crescentes benefícios à população xiita iraquiana - a qual se fazia representar pelo Jaysh al-Mahdi -, relegada a um segundo plano em meio ao regime sunita deposto. Além disso, pode-se discernir grande desequilíbrio político no Iraque logo após a intervenção, o que apresenta um cenário propício à eclosão de uma guerra civil.

Um dos fatores que chamaram a atenção de ingleses e norte-americanos, já em 2003, foi o fato de que insurgentes iraquianos logo passaram a explorar a relevância do petróleo para o Iraque e, consequentemente, a mirar infraestrutura ainda em condições de operação existentes no país, em função da importância econômica de suas reservas. Assim, àquela altura já se registraram os primeiros dos muitos atos de sabotagem aos oleodutos que cruzavam o país, o que viria a prejudicar enormemente a manutenção de todo o aparato petrolífero nacional. Devido aos problemas causados pelos atos de guerrilha aos meios de produção e de distribuição de tão importante insumo para a economia iraquiana, seriam necessários diversos anos para que se retomassem, ainda que lentamente, os níveis regulares de produtividade (Cf. ETHEREDGE, 2011, p. 38-40). A natureza da insurgência denota, assim, o envolvimento de elementos do alto escalão do governo deposto, pois atividades de tal tipo demandam largo conhecimento e experiência na área para que se possam utilizar tais aparatos e para proceder a tais atos de sabotagem.

É importante notar que os eventos que deram início à formação do Estado Islâmico e que motivaram as ações por ele perpetradas puderam ser notados logo desde o pós-guerra. Uma sequência de acontecimentos políticos, sociais, econômicos e militares se iniciou muito antes da formação da organização que se denominaria Estado Islâmico do Iraque e da Síria. Como hoje se pode observar, a insurgência iraquiana começou a atuar contra as forças políticas contrárias aos seus interesses já no dia seguinte à deposição de Saddam Hussein da presidência do Iraque em 2003 (Cf. ABUHANIEH, 2015, p. 25). Na ocasião, um indivíduo conhecido como Abu Musab al-Zarqawi iniciou uma campanha insurgente com um grupo bem preparado e organizado denominado Jama'at al-Tawhid wal-Jihad. ${ }^{17} \mathrm{O}$ fato de ter havido uma reação tão rápida e organizada demonstra que havia preparação anterior à eclosão da intervenção anglo-americana por parte de determinados grupos. Al-Zarqawi, cujo nome original era Ahmad Al-Khalayleh, logo se revelaria como o cabeça de uma organização que não só iria enfrentar as forças militares regulares

\footnotetext{
${ }^{17}$ Do árabe, "Organização de Monoteísmo e Jihad". Trata-se de um grupo militante jihadista jordaniano surgido em 1999, mas que atuou de forma independente durante a insurgência iraquiana (Cf. ALEXANDER e ZUHUR, 2010, p. 618).
} 
ocidentais, mas que também seria a origem de um movimento insurgente de grande magnitude.

A organização Al-Tawhid Wal-Jihad, que originariamente atuava no noroeste do Iraque, possuía dentre a maioria de seus integrantes cidadãos não-iraquianos. Desde o início das operações de insurgência, o grupo tornou-se conhecido por sua postura extremamente agressiva, perpetrando inúmeros atentados terroristas com o uso inclusive de explosivos, de modo a ultrapassar os limites de violência normalmente observados em conflitos desse tipo. Além disso, se valia do uso de eficientes veículos de mídia, o que o tornou conhecido como um dos símbolos da insurgência iraquiana contra os Estados Unidos. Já a essa altura, a utilização de recursos tecnológicos de alto nível, aliada ao emprego de eficazes táticas de guerrilha, permitiram ao grupo em tela despontar dentre as dezenas de outros grupos identificados como componentes da insurgência iraquiana. É justamente nesse cenário que a imagem de Abu Musab al-Zarqawi rapidamente se torna sinônimo da crueldade e de desmedida violência, especialmente em razão da disseminação de imagens registrando diversas formas de assassinatos indiscriminados tanto de civis quanto de militares capturados pelos jihadistas. Dentre as práticas do grupo se destacou ainda a destruição de símbolos da nova ordem política que o governo americano começava a instalar no Iraque. Contudo, a divulgação de arquivos exibindo a execução de prisioneiros trajando roupas similares àquelas utilizadas pelos prisioneiros de Guantánamo, sob administração norte-americana, foi sem dúvida a ação que marcou mais fortemente as atividades desse grupo em meio à comunidade internacional. Em decorrência dessa estratégia, Al-Zarqawi logrou tornar-se uma das mais importantes figuras em meio à guerra do Iraque, angariando amplo apoio e admiração por parte dos iraquianos que se encontrava em condições de vida precárias e que, por isso, viam na intervenção liderada pelos Estados Unidos a principal causa de sua situação socioeconômica (Cf. PLEBANI, 2014, p. 5).

Vale atentar para o significado desses atos, os quais, segundo o próprio líder do grupo, tratavam-se de uma resposta direta à agressão por parte da coalizão liderada pelos Estados Unidos em solo iraquiano. Daí se pode compreender que a reação da insurgência iraquiana nada mais foi do que uma mensagem relacionada à subjugação e à humilhação experimentadas por grande parte da sociedade iraquiana às imposições por parte da nova administração naquele país. Na realidade, o público-alvo das imagens difundidas pelo grupo salafista-jihadista liderado por Al-Zarqawi se tratava da comunidade islâmica em seu conceito mais amplo, ultrapassando-se os limites da 
sociedade iraquiana. A propaganda utilizada pelo grupo insurgente, pelo que se infere, já possuía por objetivo, desde seu início, alcançar indivíduos e comunidades além daquelas localizadas no território em que o grupo atuava. Ou seja, as ideias propagadas pelo grupo se valiam da subjugação de uma parcela da sociedade iraquiana - mais precisamente a sunita - para atingir a opinião pública em diversos países árabes ou de maioria muçulmana. Dessa forma, problematizou-se uma questão local para algo de amplitude internacional, dentro da comunidade islâmica, elevando-se o sofrimento de determinadas comunidades iraquianas a uma ideia de sofrimento que seria experimentado pela comunidade muçulmana, mormente aquela identificada pelo sunismo.

Cabe também ressaltar que o fato de o grupo de Al-Zarqawi ser composto majoritariamente por não-iraquianos não se constituiu em um obstáculo para seu sucesso na fase inicial da insurgência naquele país, ainda que, certamente, tenham ocorrido alguns empecilhos de ordem étnica e tribal. Principalmente fora dos grandes centros urbanos do Iraque, elementos dessa natureza têm grande peso nas relações de poder, o que favoreceu o recebimento de político ao Al-Tawhid Wal-Jihad. Da mesma forma, dadas as árduas condições de vida experimentadas pelo povo iraquiano em geral no início dos conflitos que se seguiram à intervenção norte-americana, os grupos insurgentes, sem exceção ao Al-Tawhid Wal-Jihad, enfrentaram grandes dificuldades para obter acesso a recursos materiais diversos. Ainda assim, mesmo tendo de lidar com graves problemas logísticos nessa fase inicial da insurgência, a escassez de recursos não foi obstáculo ao incremento político da organização, ao contínuo aumento de seus seguidores e, por conseguinte, à expansão territorial observada em território iraquiano a médio e longo prazo.

Problemas logísticos, no entanto, foram só parte dos obstáculos a serem superados por Al-Zarqawi e seu grupo. O fato de tanto os integrantes do grupo quanto seu próprio líder serem estrangeiros dentro do Iraque se apresentava como um empecilho à parte. Contudo, Al-Zarqawi soube explorar muito bem a questão da nacionalidade dentro do contexto da insurgência iraquiana. O jordaniano passou a favorecer e a estimular a coesão entre os integrantes de sua organização e a lealdade destes entre si e para com sua liderança, em detrimento do acesso de novos membros, fossem estes iraquianos - os quais tendiam a vê-los como como alheios às suas comunidades - ou estrangeiros e membros de outros grupos insurgentes - os quais tinham na ideologia extremista de Al-Zarqawi um impeditivo para que a ele se juntassem. Ou seja, Al-Zarqawi e seu grupo, ainda que estrangeiros no Iraque e estranhos às comunidades ali estabelecidas havia séculos, lutavam contra invasores do território sem terem como prioridade o apoio 
das massas. Contudo, ao invés de se conformar com uma condição desfavorável, o grupo de Al-Zarqawi procurou em todas as oportunidades demonstrar sua força em meio à insurgência. O próprio apelido de longa data pelo qual Al-Zarqawi ficou conhecido, $A l$ Gharib ("o estrangeiro", em árabe) foi útil aos seus propósitos de liderança do grupo - e, como se veria mais tarde, à liderança da própria insurgência iraquiana (Cf. PLEBANI, 2014 , p. 5). Esta característica do grupo seria uma importante plataforma de propaganda para a organização em si, que se manteve coesa e unida, fortalecendo ainda mais suas motivações baseadas na ideologia salafista-jihadista, de forma bastante similar àquela utilizada pela a Al-Qaeda.

Nota-se, assim, que o grupo visou utilizar-se de uma posição que, à primeira vista, apontaria para certa desvantagem política do grupo salafista-jihadista. Partindo daí, lançou-se a ideia de que o isolamento social de que sofriam e as críticas recebidas tanto no campo religioso quanto político indicariam o empenho do grupo em seguir o caminho que sua ideologia lhes indicava. A estratégia utilizada por Al-Zarqawi de sobrepor a importância da coesão do grupo através da lealdade à sua liderança e à popularidade de suas ideias pode ser melhor compreendida ao se conhecerem as análises de Brian Fishman a respeito. Este pesquisador observou que a estratégia adotada por Al-Zarqawi tornou seu grupo mais resiliente, embora lhe tenha tolhido a capacidade de criar um consenso perante a comunidade sunita de que teria condições suficientes de obter qualquer controle político no Iraque (Cf. FISHMAN, 2006, p. 22-3). O autor, percebendo o valor da condição em que se colocava esse grupo jihadista, denomina-o de paradoxo de Gharib (mantendo-se nesta denominação o termo árabe utilizado por seu líder), ou seja, o paradoxo do estranho. A denominação de "estranho", aliás, trata-se de apelido recorrente dentre jihadistas cujos grupos englobam membros provenientes das mais diferentes nacionalidades. A este respeito, merece destaque a visão do próprio Al-Zarqawi, o qual dirigiu-se aos seus membros garantindo-lhes que

aqueles que pertencem ao grupo vitorioso conseguem tolerar a desolação de seu caminho e não se alarmam quando vêm que só poucos homens seguem tal caminho. Eles são comparados quanto a isto somente com o melhor da criação e os eminentes profetas e mensageiros (AL-ZARQAWI, apud FISHMAN, 2006).

As circunstâncias que caracterizaram o paradoxo do Gharib foram de grande serventia aos propósitos do grupo. Afinal, a rejeição provocada a alguns serviu como motivação para outros verem em Al-Zarqawi e ao Al-Tawhid wal-Jihad como expoentes 
em meio aos diversos grupos insurgentes em território iraquiano. Em decorrência disso, a imagem do jordaniano se faria notar pela própria Al-Qaeda, de modo que esta, já a partir de outubro de 2004, passou a ter no grupo de Al-Zarqawi o seu representante no Iraque, mediante a declaração de aliança deste a Osama Bin Laden. À própria Al-Qaeda seria interessante explorar esse paradoxo, aliás, já que tal organização não possuía qualquer identificação com o Iraque ou representação em seu território. Assim, o fato de ter passado a denominar sua organização como Al-Qaeda no Iraque garantiu a Al-Zarqawi acesso a diversas fontes de financiamento, o que significaria certamente um maior influxo financeiro e um significativo aporte político e logístico (Cf. LAPIDUS, 2014, p. 885). Este foi um movimento importante para ambas as organizações envolvidas, pois enquanto o grupo de Osama Bin Laden necessitava de alguém que encabeçasse suas campanhas jihadistas contra os americanos - como uma forma de dar continuidade às campanhas iniciadas anteriormente em território afegão - Al-Zarqawi precisava garantir e legitimar sua posição de destaque em meio à insurgência iraquiana.

Isto denota que a liderança da Al-Qaeda possuiria interesse em se fazer presente no Iraque, ou ao menos em se fazer representar nesse local, dada a interpretação histórica que se abstrai da conjuntura daquele momento. A necessidade de se combater a presença dos "representantes dos cruzados" em solo iraquiano se assomava, ao que as evidências indicam, como um valioso pretexto para passar a atuar naquela região, onde poderia confrontar os norte-americanos de forma a dar sequência à jihad nos moldes da interpretação de Osama bin Laden. Para a Al-Qaeda Central, portanto, ter se feito representar no Iraque naquele momento significou o aproveitamento de uma grande oportunidade para dar continuidade à campanha de jihad global iniciada décadas antes no Afeganistão.

Ademais, Al-Zarqawi, como representante no Iraque da Al-Qaeda - esta ainda a mais importante organização jihadista em nível internacional - veria sanado seu problema referente à imagem negativa junto a futuros membros em potencial, a quem a propaganda da Al-Qaeda ainda falava mais alto. A questão mais importante desse momento, entretanto - talvez mais até do que a questão do financiamento, que alavancaria suas capacidades operacionais - foi ter Al-Zarqawi passo a ser tido como um legítimo líder salafista-jihadista no Iraque, o que era sinônimo de poder perante os demais grupos insurgentes e, ainda mais significativamente, frente a futuros seguidores (Cf. PLEBANI, 2014, p. 6). 
Após a adoção da denominação de Al-Qaeda no Iraque, esta logo se destacou como um dos grupos mais poderosos dentre aqueles que compunham a insurgência iraquiana. No entanto, a singularidade de suas ações, que mantinham alto grau de violência como marca característica, não chegou a ser um chamariz para os adeptos de outros grupos insurgentes agindo no Iraque na ocasião. Da mesma forma, não obteve significantes vitórias sobre as forças da coalizão liderada pelos Estados Unidos, o que incluía as forças armadas regulares do Iraque, o que indica que não logrou conquistas territoriais importantes naquele período. Tem-se, daí, que o fato de ter se tornado representante de uma organização do porte da Al-Qaeda não trouxe, em termos práticos, grandes vantagens ao grupo de Al-Zarqawi, quando comparado aos demais grupos armados insurgentes e a capacidade de cooptação de novos indivíduos. Considerando-se os objetivos propostos pelo jordaniano para seu grupo, fica evidente que os frutos colhidos com uma mera representação da liderança de Osama Bin Laden no Iraque ficaram muito aquém das expectativas.

\subsection{A AL-QAEDA NO IRAQUE}

Em que pesem os prejuízos materiais, as perdas humanas e as consequências de todas as atrocidades cometidas por grupos insurgentes iraquianos sunitas, estes não vieram a impedir a transição política organizada pelas forças estrangeiras. Mas a violência crescente se mostrou o suficiente para motivar o debate entre cidadãos, imprensa, formadores de opinião e políticos acerca de suas atividades no Iraque. Os insurgentes sunitas tinham como alvo as forças estrangeiras, tanto americanas como suas aliadas, além de funcionários do governo iraquiano e integrantes de suas forças de segurança. Há que se frisar que, uma vez destruída boa parte da infraestrutura e instituições iraquianas, os trabalhadores iraquianos acabaram por ser empregados junto a representantes do governo americano, empreiteiros estrangeiros, empresas do ramo petrolífero, de distribuição de energia e outros. Em 2007, um bombardeio ao parlamento iraquiano ocorreu em meio a crescentes ataques, servindo para demonstrar a capacidade da insurgência para operar até mesmo na capital iraquiana. No auge da insurgência, bairros dominados por sunitas em Bagdá acabavam por servir de bastiões a serviço de grupos rebeldes, enquanto diversos bairros xiitas acabavam sendo dominados por diferentes grupos sunitas (Cf. NAYLOR, 2009, p. 59-60). 
A duração e intensidade das ações perpetradas por tais grupos insurgentes contrariaram as expectativas dos estrategistas anglo-americanos, provavelmente porque contaram com o apoio por parte de grande parcela da população sunita do Iraque, a qual compartilhava do sentimento de humilhação externado pelos insurgentes. No processo pós-intervenção norte-americana ao Iraque, a configuração das forças políticas permitiu divisar uma interessante convergência de interesses no país, envolvendo a Al-Qaeda no Iraque e os antigos funcionários do regime deposto de Saddam Hussein, pertencentes ao partido Baath, os quais sempre tiveram forte conexão com a população sunita iraquiana (Cf. DINIZ, 2010, p. 206). Tanto aos antigos funcionários do regime deposto quanto à Al-Qaeda no Iraque não interessava a constituição de um novo governo, pois este seguramente relegaria à parcela sunita uma posição de pequena relevância nas esferas política e social. Considerando as características da sociedade iraquiana, o fato de passarem a ser governados por curdos e xiitas - ainda que iraquianos - na mentalidade dos sunitas insurgentes não fazia sentido tampouco seria bem aceito. $\mathrm{O}$ estabelecimento de um novo governo em meio a tais situação, aliás, dificilmente contribuiria para com a manutenção das condições econômicas e sócio-políticas almejadas pela população sunita. Dentre as motivações que podem ser identificadas dentre os insurgentes sunitas e seus colaboradores pode ser identificada a tentativa de estes realocarem ao poder os representantes do partido Baath. Ou seja, infere-se que aos sunitas interessava, no cenário pós-guerra, manter a mesma configuração social observada no período em que Saddam Hussein estivera no poder (Cf. POLK, 2006, p. 198).

De outro lado, tem-se a parcela xiita da população, que passou a ser ver protegida pelo seu representante, o presidente Al-Maliki, o qual fora conduzido ao poder através de eleições democráticas em 2005 tuteladas pelo governo americano. Além do presidente, os xiitas passaram a contar ainda com o Primeiro Ministro e com ampla maioria no parlamento daquele país. Assim como no regime governamental anterior, a administração do xiita Al-Maliki também passou a receber graves acusações a respeito de casos de corrupção e da prática de violência contra seus opositores sunitas. Tais circunstâncias colaboraram para que se acentuassem ainda mais as diferenças políticas e sectárias entre xiitas e sunitas no Iraque, vindo os últimos a se considerar como uma parcela da sociedade que se encontrava excluída e marginalizada. Em resposta a essa alteração de poder, grupos sunitas passaram a organizar protestos populares, logo passando a apelar à violência em praticamente todo o território. Neste ponto se percebe forte influência da Al-Qaeda no Iraque, a qual se insere em um panorama desfavorável 
aos sunitas, passando então a realizar inúmeros atentados terroristas, cujas características e motivações evidenciavam a questão sectária. Tais ataques visavam, claramente, destituir o novo governo e, concomitantemente, atingir a parcela xiita da população (Cf. VISENTINI, 2014, p. 200-2).

Com as eleições multipartidárias de 2005 esperava-se que se iniciassem processos democráticos em meio à sociedade e que o Iraque iniciasse, então, a um desenvolvimento à luz dos interesses dos norte-americanos, de modo a servir ainda de inspiração aos outros Estados árabes ainda não alinhados aos Estados Unidos. Este quadro opôs uma aliança entre o Supremo Conselho Islâmico do Iraque e o partido $D a^{\prime} w a^{18}$ apoiados pelos Estados Unidos - ao já citado grupo Jaysh al-Mahdi, que dispunha de um braço militarizado. Observou-se então uma escalada nos problemas políticos no Iraque, uma vez que os xiitas, representando cerca de $65 \%$ da população do país, tornaram-se politicamente mais influentes do que jamais poderiam ter sido sob o governo da minoria sunita de Saddam Hussein (Cf. STOKES, 2009, p. 317).

O ano de 2005 viria a apresentar à Al-Qaeda no Iraque uma configuração sócio-política pouco favorável no que se refere à população sunita iraquiana, a qual participara maciçamente das votações presidenciais do país em dezembro, após já terem demonstrado também expressiva participação durante o referendo constitucional realizado dois meses antes. Mesmo tendo os sunitas boicotado as eleições realizadas em janeiro, o simples fato de esta comunidade ter contribuído para com a estabilidade política do Iraque se colocou como uma questão crucial para o grupo jihadista. Cônscio da dependência do apoio dos iraquianos sunitas para o desenvolvimento de sua organização, Al-Zarqawi percebeu nesses movimentos uma configuração política desfavorável, já que justamente a população cujo apoio lhes era vital agora contribuía para com a estabilização do país, o que também não interessava ao grupo.

Compreende-se, por conseguinte, ao se avaliar o caráter insurgente do grupo e sua base ideológico-religiosa, que este dependia de dois elementos para prosseguir com sua campanha: a instabilidade política e o apoio sunita. Caso houvessem os sunitas obtido sucesso em garantir representação suficientemente favorável nas instituições

18 Do árabe "convite" ou "chamado." O termo pode ser empregado com o sentido de "mobilização islâmica." No caso em questão, entretanto, trata-se de partido político iraquiano composto basicamente de uma aliança de figuras políticas e lideranças xiitas (Cf. HEDIN, JANSON e WESTERLUND, 2004, p. 1704). 
democráticas instaladas pela coalização que então conduzia o Iraque, muito provavelmente passariam a contribuir cada vez mais para com a estabilização política, econômica e social do país, condição esta que não seria interessante aos propósitos da AlQaeda no Iraque. Em havendo melhores condições sociais, deixaria de importar às diferentes comunidades iraquianas - inclusive sunitas - o apoio a grupos insurgentes, já que a luta armada ou outros meios não democráticos em nada contribuiriam para a almejada estabilidade social.

Observa-se, pois, que a participação sunita nos processos democráticos acabou por significar à Al-Qaeda no Iraque uma ameaça, já que contribuíra para com a desconfiguração de um cenário conveniente ao grupo salafista-jihadista. Fica clara esta constatação ao se notar que foi justamente a partir do início de 2006 que a organização passou a ter na população xiita do Iraque o principal alvo de suas ações terroristas, promovendo disputas religiosas, o ódio entre comunidades e a competição entre sunitas e xiitas. Para tanto, a Al-Qaeda no Iraque "realizou centenas de ataques contra alvos civis, religiosos e políticos que culminaram com o bombardeio de Samarra, geralmente considerado como o evento que marcou o início da guerra civil iraquiana" (Cf. PLEBANI, 2014, p. 6). Fica patente o crescimento da importância do grupo dentro da disputa política no Iraque, ao tomar para si extensos territórios dentro do país em função de sua força militar, a qual se valia, acima de tudo, de táticas que instrumentalizavam a violência através do terrorismo para infligir medo tanto a civis quanto aos integrantes das forças armadas regulares iraquianas e estrangeiras.

$\mathrm{O}$ fato de ter a Al-Qaeda no Iraque infligido inúmeros ataques tanto diretamente à população xiita quanto a seus grupos armados fez com que a organização passasse a se tornar alvo de enorme criticismo por parte de muçulmanos em todo o mundo, incluindo-se de outros grupos jihadistas, os quais viam nas táticas da Al-Qaeda no Iraque uma exacerbada crueldade. Dentre tais críticas destaca-se a menção de que o direcionamento de ataques terroristas a grupos xiitas, ao invés de militares da coalizão encabeçada por americanos, se constituiria em grave erro estratégico. A estas críticas se somou o próprio mentor de Al-Zarqawi, Al-Maqdisi, o qual, juntamente com outros líderes da Al-Qaeda Central, dirigiu duras críticas à forma de atuação do grupo de AlZarqawi, entendendo serem descabidos os ataques daquele tipo contra muçulmanos xiitas (Cf. PLEBANI, 2014, p. 5-7). Neste ponto se percebe que não só a interpretação ideológica, mas também a atuação do grupo da Al-Qaeda no Iraque, deixaram de ser motivo de apreciação e simpatia por parte de fundamentalistas islâmicos sunitas, tendo se 
tornado motivo de condenação. Esta lide deu início ao afastamento de outras organizações em relação à Al-Qaeda no Iraque, as quais, se anteriormente indicavam apoio e colaboração, passavam agora a contrariá-los no campo ideológico-religioso, vindo até mesmo a desestimular o apoio futuro de outras instituições e indivíduos.

Essa condição passava a colocar a Al-Qaeda no Iraque, e principalmente a figura de seu líder, à margem do pensamento e da aprovação da maioria dos salafistasjihadistas, os quais observavam atentamente o desenrolar da guerra civil iraquiana. Essa organização, a exemplo das demais franquias e ramificações da Al-Qaeda Central, possuíam extensa autonomia para programar suas ações, planejar seus ataques e até para administrar o financiamento de seus grupos. A autonomia desses grupos signatários da liderança de Osama Bin Laden era grande, o que os tornava independentes na maior parte de suas atividades. Em decorrência disso, a prática da violência exacerbada por parte da Al-Qaeda no Iraque se colocou como um obstáculo cada vez maior às pretensões da AlQaeda Central no cenário iraquiano, criando-se assim enorme tensão entre a liderança central e Al-Zarqawi (Cf. WILNER, 2011, p. 59). Tal situação se agravaria e se tornaria insustentável, uma vez que uma completa concordância ideológica entre a organização central e sua representante seria fundamental para a sustentação das relações de poder, apoio financeiro, político e, principalmente, a coesão de seus integrantes.

A política americana recentemente instituída no país, ao que se permite perceber, relegou os sunitas a um segundo plano social e político, notadamente por serem percebidos como nocivos ao novo poder que se constituía, dado seu papel em meio à administração anterior. Paralelamente a isso, a hostilidade comum a xiitas e curdos face aos sunitas era potencializada pela instabilidade e aberta confrontação política observada no período. Estes elementos podem ser percebidos como tendo grande importância para a compreensão dos motivos e objetivos da resistência sunita no Iraque (Cf. HASHIM, 2012, p. 174).

A posição em que se encontravam no tabuleiro político iraquiano serviu de motivação para que grupos sunitas, antigos aliados do presidente deposto, se rebelassem contra a ocupação americana por meio de guerrilhas formadas por membros do partido Baath, chefias tribais, oficiais do exército e agentes de segurança da administração de Saddam Hussein. Na sequência, registrou-se uma dissenção entre os próprios sunitas, sendo que uma parte da insurgência propunha a restauração do poder sunita árabe, enquanto a outra lutava por estabelecer um estado islâmico salafista. As questões 
sectárias, portanto, seguiam como importante elemento no jogo político no Iraque. A ausência de uma unidade de demandas e propostas políticas dentre as diferentes comunidades iraquianas, ainda que pertencentes a um mesmo grupo étnico ou religioso, produzia uma multiplicidade de grupos que almejavam o poder. Atuando principalmente conforme suas peculiaridades ideológico-religiosas, tais grupos passaram a compor a insurgência iraquiana, sem, contudo, apresentarem qualquer tipo de coesão. Isto, por si só, já se coloca como um obstáculo à representatividade dos grupos insurgentes em relação à população distribuída por todo o território iraquiano. Esta realidade acabaria por se constituir em uma lacuna de poder em meio à própria insurgência, pois não havia uma organização que despontasse em relação às outras de forma a ocupar algum tipo de liderança, o que impediu que houvesse uma representatividade efetiva à frente à população iraquiana.

A falta de representatividade das comunidades de diferentes regiões espalhadas pelo território iraquiano, agravada pela ausência de coordenação entre os grupos insurgentes acabou, em grande medida, viabilizando o desenvolvimento de um grupo cada vez maior, mais poderoso e bem coordenado - a Al-Qaeda no Iraque. Em meio a tal situação, essa organização acabou por ocupar a lacuna de poder, estabelecendose como responsável pela futura coordenação e organização de combatentes sunitas de diferentes origens que se encontravam no Iraque, conduzindo-os à luta contra as forças invasoras de suas terras. Paralelamente, engendravam esforços no sentido de impedir que representantes xiitas lograssem obter influência e poder político no país, já que estes, na visão de Al-Zarqawi, estavam permitindo e incentivando as ações norte-americanas e as implantação de suas instituições no país.

Para se compreender melhor a forma de operação da organização a esta altura denominada Al-Qaeda no Iraque se torna necessário avaliar o papel desempenhado por seu primeiro líder, responsável não só pelo estabelecimento de seus grupo como uma organização de fato, mas também por seu desenvolvimento em meio à insurgência iraquiana sob a bandeira do salafismo-jihadismo.

\subsubsection{A influência de Al-Zarqawi}


Conhecer alguns aspectos primordiais da mentalidade de Al-Zarqawi é de extrema importância para se compreender não somente seus atos frente aos grupos insurgentes que liderou - quaisquer que fossem suas denominações - mas também dos indivíduos que o seguiram, desde a fase embrionária do Estado Islâmico. Ao se conhecerem as ideias defendidas e os preceitos estabelecidos por Al-Zarqawi diante de seus seguidores, bem como ao se avaliarem as ações de sua responsabilidade ao longo de vários anos, percebe-se que a questão religiosa não é preponderante para os objetivos estabelecidos e meios adotados. Compreender a personalidade dos líderes de organizações salafistas-jihadistas, tanto em nível organizacional quanto pessoal, é fundamental para se entender seu modo de funcionamento. Mais do que exercer notável influência sobre seus partidários, uma liderança carismática serve de atrativo para novos integrantes para a organização de que fazem parte e para a causa que defendem. Aparentemente, o papel de Al-Zarqawi na liderança de seu grupo foi eficaz, nesse sentido, junto a milhares de indivíduos (Cf. GERGES, 2016, p. 129).

A força das ideias e das palavras de Al-Zarqawi foram essenciais para o sucesso do Estado Islâmico em sua fase de desenvolvimento. Sua mentalidade o tornou destaque dentre um enorme número de salafistas-jihadistas mundo afora, o que o caracterizou, na visão de muitos, como um novo ícone do movimento salafista na atualidade. Em contrapartida, muitas das ideias difundidas pelo jordaniano também lhe renderam grandes críticas, inclusive por parte de líderes salafistas-jihadistas, muitos dos quais se mostraram avessos aos atos incentivados e praticados pelo grupo que agora se denominava Al-Qaeda no Iraque. Ademais, no entendimento de diversos líderes religiosos muçulmanos mundo afora, as ideias de Al-Zarqawi eram tidas como inaceitáveis dentro do islamismo, vindo estes a expressar seu descontentamento com as ações por tal organização ao mencionar que a mesma sequer representaria o Islã (Cf. NAJI, 2006).

No que tange à origem da mentalidade de Al-Zarqawi, há que se entender que esta foi em grande parte moldada pela ideologia propagada por Abu Muhammad AlMaqdisi, um ideólogo salafista-jihadista e seu conterrâneo, que conheceu durante sua prisão em Al-Jaffar, na própria Jordânia. Durante o período em que Al-Zarqawi conhecido naquela época em meio à criminalidade comum como um bandido violento, oriundo do submundo do crime - permaneceu naquela prisão, teve a oportunidade de conhecer Al-Maqdisi, de quem, mais do que ter recebido ensinamento religioso, absorveu ideias extremistas embasadas no salafismo. No caso de Al-Maqdisi, o principal motivo 
que o levara a ser preso na rigorosa prisão de Al-Jaffar foi justamente a disseminação de suas ideias fundamentalistas salafistas, o que o tornou inimigo do governo jordaniano. Tinha-se, portanto, um preso político transmitindo seu pensamento a um criminoso comum. Tal combinação permitiu que um indivíduo de caráter violento, como o passado de Al-Zarqawi registra, absorvesse ensinamentos religiosos ligados a uma ideologia que, em certas interpretações, prega a violência como meio a ser adotado em determinadas circunstâncias ou fins.

Para que se compreenda melhor a que tipo de ideologia foi Al-Zarqawi exposto por Al-Maqdisi, vale a pena examinar a trajetória deste último com mais pormenor. Al-Maqdisi, durante seus estudos na Universidade de Mosul, realizou extensas pesquisas junto a obras de diversos islamistas como Muhammad ibn Abd Al-Wahhab, líder religioso originário da Península Arábica do século XVIII e fundador da doutrina de pensamento que se tornou conhecido por wahhabismo. Seus princípios logo se tornaram parte da ideologia de Al-Maqdisi. Com relação a estas práticas religiosas, aliás, defendia Abd Al-Wahhab que seriam motivo suficiente para se dar início a uma cruzada em nome da restauração da fé muçulmana (Cf. HIRO, 2002, p. 39). Objetivava, com a difusão de suas ideias, a criação de um Estado islâmico independente do Império Otomano, organizado conforme seus ensinamentos puritanos. Ressalte-se que, em que pese AlWahhab distinguir a esfera política da religiosa no contexto da formação de um Estado, viria a reconhecer que o sucesso da difusão de suas ideias dependeria do apoio de governantes políticos. O pensamento wahhabita trata-se, em síntese, de ideologia que estimula uma reforma religiosa radical, trazendo em seu cerne a crença e a prática do islamismo de caráter fundamentalista, a ser praticado conjuntamente pelo Estado e por sua população (Cf. SILVA, 2016, p. 94-5).

Abd Al-Wahhab, por sua vez, fora influenciado por Ibn Taymiyya, teólogo islâmico do século XIII-XIV, cujas ideias seriam resgatadas pelo grupo salafista-jihadista cuja interpretação da jihad viria a ser aquela adotada futuramente pelo Estado Islâmico. Interessante observar os registros de que, por ocasião da invasão mongol à Síria em 1296, esse teólogo denunciou uma colaboração de grupos xiitas com os invasores mongóis, motivo pelo qual passou a defender incursões contra os mesmos em nome da defesa do califado abássida e seus aliados. Por tais motivos e interpretações, posteriormente Ibn Taymiyya incentivou seus conterrâneos a empreenderem a jihad contra os xiitas (Cf. LAOUST, 1987, p. 951-5). Portanto, seguindo essa linha de raciocínio, a perseguição aos xiitas - considerados hereges, juntamente com drusos e alauítas - mediante a instituição 
da jihad se apresentava como opção aceitável aos sunitas, o que serviria inclusive para melhor definir sua diferenciação em relação aos xiitas.

Al-Maqdisi tornou-se famoso dentre os demais autores muçulmanos da presente geração devido a seus livros de cunho político-religioso em que critica governantes de países árabes seculares, clamando pela sua destruição por vê-los como como anti-islâmicos. Suas obras, dentre as quais se destaca aquela intitulada $A$ Democracia é uma Religião, se tornaram tão influentes no mundo muçulmano que AlMaqdisi chegou a ser tido pelo governo norte-americano como o mais importante novo pensador dentre os intelectuais jihadistas. Mesmo já tendo outros pensadores fundamentalistas islâmicos criticado impetuosamente como corruptos e infiéis aqueles que não se atinham aos preceitos islâmicos de ordem sunita - a exemplo de Sayyid Qutb - a visão de Al-Maqdisi é particularmente crítica à forma como deveriam se portar os muçulmanos, individualmente, com relação a tais regimes. No entendimento deste, cada muçulmano possuria a obrigação de agir em casos de evidente heresia por parte de seus governantes. Nestes casos, não sendo suficiente denunciá-los, colocando o autor que, em vez disso, Deus compeliria os muçulmanos a matá-los (Cf. WARRICK, 2016, p. 58).

A influência de Al-Maqdisi junto a Al-Zarqawi pode ser ainda claramente percebida ao se analisar a prática da violência por parte dos integrantes da Al-Qaeda no Iraque. Para estes, provocar a morte de suas vítimas de maneira extremamente violenta parece ser um dos principais métodos para a consecução de seus objetivos políticoideológicos. Uma avaliação muito útil acerca desse ponto é registrada pelo pesquisador Hasan Abu Hanieh, intelectual bastante próximo a Al-Maqdisi, o qual, ao tratar de seu pensamento, coloca que sua conclusão radical foi de que se os líderes forem infiéis aos preceitos islâmicos, os muçulmanos deveriam matá-los. $\mathrm{O}$ assassinato, nessa visão, era o ponto chave. Essa era uma mensagem que ressoava junto aos muçulmanos que sentiam que os regimes governamentais eram incompetentes para assumirem a liderança de comunidades muçulmanas, o que permitiria aos estrangeiros ocupar as terras árabes. Através desse raciocínio, Al-Maqdisi não somente estava validando suas visões extremistas, mas estava transmitindo ainda a seus seguidores que estes eram obrigados a fazer algo a respeito desses líderes (Cf. WARRICK, 2016, p. 58-9).

A intervenção norte-americana sinalizou para muitos no mundo árabe a possibilidade de o Iraque adentrar a uma nova fase de sua história, como um país liberado da opressão de Saddam Hussein. Um país mais livre e que estaria em condições de se 
reinventar e se desenvolver. Todavia, a insurgência liderada por Al-Zarqawi passou a conduzir o Iraque rapidamente para uma guerra civil. Na leitura que Al-Zarqawi fez da situação em que se encontrava o Iraque, percebeu que as investidas dos grupos rebeldes, como logo se pôde observar, deveriam ser dirigidas não somente aos novos mandatários do país - ou seja, os interventores americanos, e mais tarde, os representantes iraquianos democraticamente eleitos -, mas também a outros Estados que se postavam como aliados norte-americanos no Oriente Médio, a exemplo da Jordânia. Assim, organizações nãogovernamentais e seus colaboradores também se tornaram alvo do conflito, ainda que lá estivessem com a finalidade de contribuir para com a melhoria das condições de vida e de recuperação da população afetada pela guerra. Então, a população iraquiana xiita tornou-se alvo dos combatentes insurgentes sunitas, principalmente em razão da política americana de alocar representantes xiitas em postos-chave da administração governamental. $\mathrm{O}$ fato de muitas das funções militares terem sido designadas a xiitas se apresentou como elemento relevante para os insurgentes, uma vez que a maioria dos combatentes rebeldes ocupava tais postos. Ou seja, as novas forças militares regulares do país eram compostas, sobretudo, por aqueles que haviam despejado a população sunita de seus status social e que agora ocupavam seus cargos atuais ilegitimamente, dada a forma como se deram tais mudanças (Cf. GRIFFIN, 2016, p. 10). O ressentimento em meio aos sunitas oriundos das classes militares foi, portanto, bastante explorado pelas lideranças insurgentes durante a fase pós-guerra.

Encontra-se aqui um ponto importante com relação aos valores sobre os quais se pauta a sociedade iraquiana, sobretudo no que tange aos aspectos culturais, o que AlZarqawi, ao que se percebe, soube muito bem explorar. Vale entender algumas dinâmicas existentes nas chamadas "sociedades de vergonha" - para utilizar o conceito empregado por Evelin Lindner (2006) - como ocorre na maioria dos países árabes, incluindo-se a Síria e o Iraque, os quais se encontram dentre os objetos de estudo neste trabalho. A externalização das normas leva os indivíduos a procurar manter a qualquer custo a honra e reputação familiar dentro da rede social em que estão inseridos, pois tal rede é tida como o principal ambiente de sobrevivência naquelas sociedades. Assim como em outras sociedades árabes, no caso do Iraque os conceitos de honra e de humilhação são tidos como as piores maneiras de se causar desgraça a um indivíduo perante os demais. Humilhações e atentados à honra são considerados, entre os iraquianos, como uma "morte social", vista como pior do que a própria morte. Conceitos como esses não são novidade para representantes do governo norte-americano, pois já durante a Segunda Guerra 
Mundial oficiais do exército norte-americano recebiam instruções acerca do chamado "sistema de honra" iraquiano, de modo que soubessem lidar adequadamente com quaisquer pessoas daquele país, incluindo-se figuras do governo (Cf. FONTAN, 2009, p. $\mathrm{x})$.

No bojo de uma sociedade cujas relações são pautadas pela vergonha, a humilhação torna-se a pior forma de desgraça possível. Sendo as comunidades tão diferentes e separadas entre si, dado o fator da identidade tribal, a sobrevivência do indivíduo é praticamente impossível fora do círculo social a que pertence. Consequentemente, utilizar-se de assassinatos pela honra de determinado indivíduo, em um ambiente social como esse, é tido como essencial para se resgatar a honra contra a qual se atentou. Ademais, numa comunidade formada por uma estrutura piramidal baseada no apoio socioeconômico envolvendo cada núcleo familiar - sempre dentro do conceito tribal e étnico sobre os quais se sustentam a esmagadora maioria dessas sociedades -, cair em desgraça social significará literalmente ficar sem recursos, estando fadado à extrema pobreza. A dinâmica social, aliás, pode-se correlacionar humilhação colonial, exercida por estrangeiros durante os conflitos ocorridos no Oriente Médio em épocas anteriores (Cf. FONTAN, 2009, p. 15-8).

Para melhor entender este fenômeno, vale recorrer aos trabalhos da psicóloga Evelin Lindner, que tratou extensamente da questão da humilhação em cenários de conflitos. Nesse sentido, estabelece a autora que para que se consolide um ato considerado como humilhação há que se verificar a existência de três elementos: "o ato do perpetrador, a percepção da vítima resultante do ato vivenciado, e o processo social por meio do qual se considere tal ato humilhante" (Cf. LINDNER, 2006, p. xiv). No contexto em que se iniciou a Guerra do Iraque em 2003, políticos e líderes militares usaram argumentos contra o regime de Saddam Hussein que acabaram por incluir o povo iraquiano como um todo, ao mencionar a "libertação" do Iraque, pois Saddam seria uma ameaça ao "mundo civilizado". A utilização de termos como esses seria percebida pela sociedade iraquiana em geral como uma grande ofensa, pois seus cidadãos estariam sendo tratados como "nãocivilizados" (Cf. LINDNER, 2006, p. 44). O discurso daqueles que invadiram o país, bem como suas subsequentes ações, vieram a causar um sentimento de revolta em ampla parcela da população, o que certamente não era o objetivo dos norte-americanos e seus aliados quando do início de sua intervenção. Como se pode observar, as práticas norteamericanas durante o início do conflito levaram a sentimentos negativos exacerbados, notoriamente de vergonha e de humilhação, cujas consequências culminaram na 
formação de grupos organizados que tinham por objetivo restaurar a honra da sociedade à qual pertencem. Reagir à humilhação e à vergonha a que foram submetidos diante de outros povos árabes, os quais compartilham em maior ou menor grau dos mesmos valores, tornou-se primordial. Ou seja, diante de outros árabes, a vergonha que os iraquianos experimentavam seria ainda maior do que aquela relativa aos interventores, o que, a longo prazo, certamente significaria maiores problemas, principalmente de ordem social.

Além das características sociais acima avaliadas, a visão de Al-Zarqawi com relação à função de sua organização frente à nova realidade em que se inseria o Iraque, em razão das mudanças provocadas por norte-americanos e britânicos, também exige análise. O tempo histórico, na sua perspectiva, se tratava de uma repetição de fatos havidos há séculos, e que, ao que se percebe, demandavam respostas similares àquelas havidas em suas respectivas épocas. Conforme a lógica propagada por Osama bin Laden a seus seguidores e simpatizantes, os envolvidos nos atuais conflitos no Oriente Médio devem ser comparados a outros havidos na antiguidade. Nesse ponto de vista, os invasores norte-americanos são comparados aos cruzados e aos romanos, enquanto os regimes das nações árabes envolvidas são comparados a tribos árabes cristãs, como os gassânidas e os lacmidas, que antes da origem do Islã serviram, respectivamente, ao Império Bizantino e ao Império Sassânida (Cf. AMIN et al, 2006, p. 292). Nesse contexto se inserem as palavras do próprio Osama bin Laden proferidas em 2003 quando discorria sobre o significado da presença anglo-americana no Oriente Médio:

Enquanto falo, nossas feridas ainda não se curaram (...) do acordo de Sykes-Picot de 1916 entre França e Grã-Bretanha, que trouxe a dissecção do mundo islâmico em fragmentos. Os agentes dos cruzados ainda estão no poder até hoje, à luz de um novo acordo Sykes-Picot, o eixo Bush-Blair, que tem a mesma bandeira e objetivo (Apud LAWRENCE, 2005, p. 187).

No caso dos norte-americanos, mais especificamente, Osama Bin Laden compartilha da ideia de um de seus pensadores mais apreciados, o egípcio Sayyid Qutb, o qual, em suas obras, já identificava tais estrangeiros com os cruzados do século XI, colocando-os como inimigos do Islã por eras (Cf. COOPER, 2004, p. 146). Note-se, aliás, que a própria organização salafista-jihadista fundada por Bin Laden juntamente com o egípcio Al-Zawahiri no Afeganistão era chamada Frente Islâmica para o Combate aos Judeus e Cruzados; o que também corrobora com a visão dos ditos líderes quanto à comparação histórica entre americanos e cruzados. Isto demonstra o descontentamento dos extremistas islâmicos quanto a alguns países do Oriente Médio - mesmo muçulmanos 
- cujas crenças e relações com certos povos os tornam inimigos do Islã (Cf. ABUKHALIL, 2004, p. 1865). Quanto a "Islã", tanto nesta passagem como em outras em que filósofos, teólogos ou mesmo líderes de determinados grupos se refiram a essa religião, deve-se considerar sempre que o termo se relaciona à visão peculiar do salafismo e do jihadismo que compõem seus pensamentos e ideologias. Não deve interpretar o leitor, nestes casos, que o termo "Islã" se refira à religião como um todo, notando que determinadas ideologias consideram que aqueles que não compartilhem estritamente de suas visões não devem sequer ser considerados muçulmanos. Ainda que minoritário dentre os muçulmanos, tal posicionamento ideológico deve ser considerado e suas colocações observadas e interpretadas, sempre com precaução no que tange às variadas interpretações islâmicas.

A mentalidade de Al-Zarqawi viria a se refletir em suas colocações acerca de fatos históricos e seus elementos. Assim, nota-se influência histórica por parte de grupos cujas ações podem ser associadas ao que hoje se conhece por terrorismo. Um exemplo interessante a ser observado envolve o grupo kharidjita do século VII - cujo nome advém de Kharij $^{19}$ - que se afastou do grupo de seguidores de Ali - que originariam a seita xiita - disputando assim a legitimidade na condução do califado. Estes promoveram ainda uma reforma religiosa que negava a observância dos pressupostos religiosos islâmicos originais estabelecidos inicialmente pelo profeta Maomé, o que culminou no assassinato do califa Ali $^{20}$ (Cf. SHARKEY, 2017, p. 30). Acreditavam estes que qualquer califa poderia ser deposto pela força, inclusive sendo assassinado, caso não se provasse um bom líder. Os kharidjitas, embora tenham sido praticamente dizimados em lutas internas durante a primeira grande guerra civil do Islã (al fitna al khubra) entre os anos 655 e 660, deixaram como legado tanto sua conduta violenta quanto sua interpretação restrita do Corão. Tais passagens serviram de inspiração para muitos grupos radicais ao longo dos séculos, como nota Bar Shmuel, que ao avaliar a influência kharidjita menciona que

a filosofia que norteava aquele grupo, o qual tinha na jihad o centro de seus deveres, não é algo novo no Islã radical moderno. A seita kharidjita do século VII, infame na própria história islâmica como causa da guerra civil muçulmana, assumiu esta posição e implementou-

\footnotetext{
${ }^{19} \mathrm{O}$ termo pode ser interpretado como "aquele que deixa." Designou o grupo de kharidjitas que se rebelou contra o califa Ali após a batalha de Siffin, em 657, e responsáveis pelo seu assassinato. Tal revolta se deu quando o califa aceitou arbitramento junto a seu adversário, $M u$ 'waywa, ou seja, permitiu arbitragem humana no lugar da decisão da batalha que havia sido ganha por vontade divina (Cf. HIGGINS, 2004, p. 390).

${ }^{20}$ Ali ibn Abi Talib, primo e genro do profeta islâmico Muhammad, que mais tarde se tornou califa do Islã (Cf. STEIGERWALD, 2004, p. 35).
} 
a. Contudo, a doutrina kharidjita foi rejeitada como uma heresia pelo Islã antigo (BAR, 2008, p. 13-4).

A passagem relacionada ao assassinato de Ali, como Gabriel observa (2015, p. 85-6), é “um exemplo da crença de muitos grupos radicais". Este autor aponta, também, para uma conexão entre a seita kharidjita e os grupos extremistas islâmicos atuais, mencionando que esta é outra raiz do terrorismo na história islâmica. Os princípios e crenças kharidjitas têm se constituído numa ameaça de natureza terrorista a todos impérios, dinastias e sociedades desde então, o que, ainda na visão do acadêmico, coloca as milícias islâmicas atuantes hoje em diferentes partes do mundo como uma continuação do Kharij (Cf. GABRIEL, 2015, p. 85-6). De fato, a conduta dos kharidjitas guarda muitas semelhanças com a forma de atuação utilizada pelos integrantes do Estado Islâmico nos tempos atuais, como complementa Paul Grieve, o qual expõe que

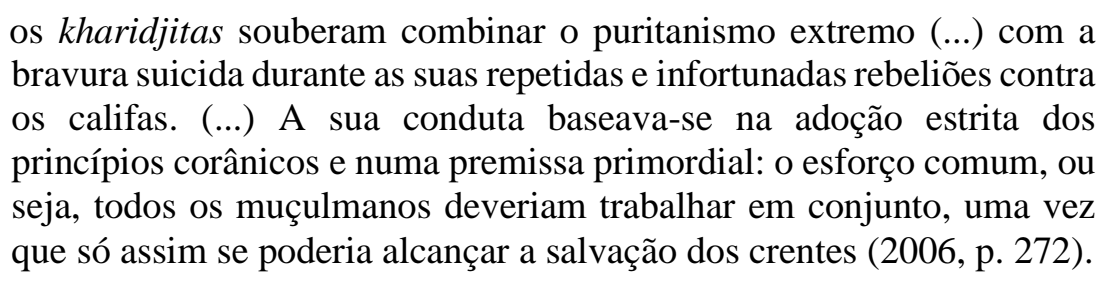

Mohammad Kamali é outro autor que divisa no grupo kharidjita um marco histórico no que se refere ao extremismo político dentro do Islamismo, distinguindo-se pela confrontação e pelo desafio à autoridade de um governo legítimo. No caso do grupo em questão, este se caracterizou como tal não só pelo fato de ter boicotado a autoridade do califa Ali ibn Abu Talib, mas também por ter entendido permissível que se matassem quaisquer muçulmanos, com exceção dos seus próprios seguidores, baseando-se na visão extremista de que o cometimento de um grande pecado - no caso, cometido pelos indivíduos que não pertencessem ao seu grupo - equivaleria à renúncia ao Islã $(2015$, p. 40).

O exemplo da influência que os kharidjitas - comunidade composta basicamente por nômades e seminômades que habitavam a Península Arábica, incluindo o território onde hoje fica o Iraque - exercem no campo cultural no Oriente Médio também parece ter influenciado a liderança do nascente Estado Islâmico. Registra-se que o grupo os kharidjitas, já do século VII, atraíram muitos seguidores de diferentes comunidades espalhadas pela Arábia Central (Cf. SILVA, 2016, p. 35), mesmo que sua 
ideologia se colocasse à margem daquilo que era difundido pelos líderes religiosos já naqueles tempos. Isto se assemelha à maneira como o Al-Tawhid Wal-Jihad, desde sua formação, recebeu cidadãos de diferentes países da região, tornando-se destino também de muitos indivíduos oriundos de outros grupos fundamentalistas e insurgentes, os quais após jurarem lealdade ao seu novo califa passam a atuar conforme os preceitos salafistasjihadistas do grupo.

Com base em tais correlações, pode-se depreender uma perpetuação de muitos valores e práticas registradas a respeito dos kharidjitas, considerados por muitos como uma facção islâmica composta por fanáticos e rebeldes idealistas, sendo claramente vinculados às ideias dos grupos islâmicos jihadistas dos dias atuais (Cf. RAHMAN, 1966). Esse quadro evidencia a conexão histórica entre kharidjitas e muitos dos terroristas islâmicos atuais, mormente os salafistas e jihadistas, como é o caso da Al-Qaeda, intimamente ligada aos grupos que futuramente comporiam o Estado Islâmico. Dada a conexão direta entre estas duas últimas organizações, cabe conhecer a explicação de Abu Khalil As'ad quanto às origens da ideologia da Al-Qaeda, a qual "é influenciada pela visão fundamentalista, pureza militante e dogmatismo dos kharidjitas do século VII, do wahhabismo e de ramificações extremistas contemporâneas da Irmandade Muçulmana egípcia" (2004, p. 1865-6). Estas colocações corroboram o entendimento de Teresa e Silva, com relação a terem sido os kharidjitas os primeiros fundamentalistas islâmicos, quando de sua rebelião contra Ali, "por este ter submetido o seu poder divino ao poder temporal do califa omíada de Damasco, Muawiya" (2016, p. 67).

O passado de Al-Zarqawi em meio à violência entre criminosos parece ter exercido importante influência à sua conduta como líder da Al-Qaeda do Iraque. Ao que se pode avaliar, as ideologias com as quais tomou contato e que mais tarde viria a propagar serviram ao mesmo tempo para canalizar sua agressividade e para lapidar seu comportamento. Se sua conduta violenta durante a adolescência, quando frequentava alguns dos bairros mais problemáticos da cidade de Zarqa, o levara à criminalidade comum. Já os ensinamentos que recebeu acerca do salafismo e do jihadismo durante o período em que passou na prisão de Jaffar o colocaram em contato com uma realidade bastante diferente, mas não necessariamente menos violenta. Pode-se entender que o comportamento de Al-Zarqawi, em sua juventude, desembocara em violência associada à criminalidade em razão dos ambientes que frequentava e das pessoas com quem convivia (Cf. WARRICK, 2016, p. 30-3). Ao ser inserido a grupos salafistas-jihadistas, 
entretanto, Al-Zarqawi não deixou de lado seu caráter violento, tendo simplesmente que alterar a natureza e forma da violência que visava praticar.

Se antes a violência fora um meio pelo qual Al-Zarqawi conquistara respeito dentre outros criminosos ou que lhe garantira algum sucesso nesse meio, após o contato com o salafismo e o jihadismo a violência passou a ser um instrumento de sua ideologia. Ou seja, no que se refere ao caráter de Al-Zarqawi, o elemento violência - ainda que manifestada de maneira muitas vezes inconsciente - se alterou em sua forma e em sua finalidade. Agora, a canalização da agressividade de Al-Zarqawi convergia para um fim ideológico, de maneira premeditada e meticulosamente planejada. As formas através das quais a violência poderia ser utilizada, o significado de sua utilização, a quem se direcionaria e sua magnitude são questões que seriam ditadas por pensadores e ideólogos islâmicos possuidores de enorme prestígio dentro de seus círculos. Não fazia mais sentido praticar agressão gratuita a quaisquer pessoas sem um propósito claro. Nessa nova realidade, a prática da violência passou a ser motivada por preceitos ideológicos definidos e aceitos pelas correntes de pensamento agora observadas por Al-Zarqawi.

Enquanto o estudo de assuntos religiosos e filosóficos permite entender melhor os objetivos da liderança do Estado Islâmico, a análise histórica admite a compreensão da origem, do desenvolvimento e dos métodos empregados pela organização. Dentro dessa lógica, tendo em vista o vínculo histórico entre os kharidjitas e o Estado Islâmico, pode-se entender o vínculo entre a forma de atuação dos dois grupos, os quais possuem na prática da violência recurso comum para lidar com disputas de cunho político e social. A prática da violência em larga escala por parte de integrantes do Estado Islâmico, direcionados tanto a indivíduos quanto a símbolos alheios ao grupo, de forma comumente caracterizada por atos de terrorismo, explicita o grau de aceitação por parte de seus integrantes quanto à ideologia de seu líder. Os valores difundidos por Al-Zarqawi dentro de suas esferas de influência eram aceitos e praticados pelos integrantes de sua organização, ainda que isso significasse eventualmente divergir das propostas de líderes políticos ou religiosos sunitas, incluindo-se assim as lideranças da Al-Qaeda, referência para Al-Zarqawi.

Do mesmo modo, percebe-se que o assassinato intencionalmente cruel de inúmeros indivíduos, ainda que não fossem representantes de ideologias ou de comunidades avessas às da Al-Qaeda no Iraque, exterioriza a intenção desta organização de se distinguir das principais correntes ideológicas islâmicas. Essa preocupação fica 
clara ao se recordar que a conduta política nada mais é do que a expressão da ideologia que a norteia. Cabe aqui assinalar a comparação feita por Barry Cooper ao descrever o pensamento de um militante salafista-jihadista a respeito da atuação do grupo a que pertencia, mencionando que "como para os kharidjitas, a vida era uma eterna jihad, uma jihad que se perpetua até que morram ou sejam mortos" (2004, p. 180).

Tendo a formação de sua mentalidade sido determinada pela ideologia salafista-jihadista, Al-Zarqawi logo adotaria providências para que seu grupo colocasse em prática as ideias de que comungava. Em decorrência das crenças disseminadas pelos mesmos pensadores extremistas que já haviam influenciado os líderes da Al-Qaeda, bem como pelo ideólogo salafista Muhammad Al-Maqdisi, Al-Zarqawi veio a desenvolver um grande sentimento de ódio ante os muçulmanos xiitas e, por extensão, a todos aqueles que não fossem seguidores do sunismo (Cf. WARRICK, 2016). Aqui há que se notar importante diferença ideológica entre Osama Bin Laden e Al-Zarqawi. O primeiro já dizia que sua prioridade seria uma questão muito mais abrangente, a que chamava de "o inimigo distante", ou seja, o governo e a sociedade norte-americanos, representantes dos valores e da conduta social ocidentais. Tão importante quanto isso, na visão do saudita, seria o fato de terem os Estados Unidos protegido e colaborado para com regimes corruptos de países islâmicos como o Marrocos e a Arábia Saudita. Al-Zarqawi, por sua vez, tinha como principal alvo de suas críticas aquilo que definia como "o inimigo próximo", cujo significado pode ser entendido com relação aos regimes governamentais árabes (Cf. FISHMAN, 2006, p. 20).

Consequentemente, e muito provavelmente em função desta diferença de entendimento e de objetivos, Al-Zarqawi também estabelecera como meta primária a formação de um Estado Islâmico no Levante, ou seja, num território que corresponde àquilo que hoje incluiria o Iraque e a Síria. Tal desígnio importa em uma estratégia para se controlarem estes territórios especificamente, e não em uma estratégia de escala global, conforme propagado pela Al-Qaeda Central. Estas distinções de escopo e abrangência, ainda que num primeiro momento possam parecer simples, indicam expressiva diferença entre Al-Zarqawi e a liderança da Al-Qaeda Central no nível estratégico. Trazidas ao nível tático, importariam em grandes disparidades de ordem operacional entre ambas as organizações. Era questão de tempo para que as diferentes formas de operacionalização expusessem as diferenças ideológicas e estratégicas entre Al-Qaeda Central e sua representação em território iraquiano (Cf. GERGES, 2016, p. 7). 
A atuação do grupo encabeçado por Al-Zarqawi manteve-se fiel aos preceitos de seu líder, deixando somente de adotar, a certa altura, os métodos difundidos por Osama Bin Laden. Isso significava à Al-Qaeda do Iraque deixar de observar o estipulado pela Central. Contudo, ainda que Al-Zarqawi e seus seguidores passassem a discordar dos métodos utilizados por Bin Laden para a consecução de seus objetivos, jamais deixaram de basear suas crenças nos fundamentos supramencionados. É interessante notar esta conexão histórica entre os dois grupos. Tal condição denota, de certa forma, que a liderança da Al-Qaeda no Iraque não só tinha profundo conhecimento de assuntos e de tradições religiosas islâmicas fundamentalistas, cuja origem remonta a diferentes tempos históricos, mas possuía também notável ciência das passagens mais marcantes da história islâmica, suas motivações, implicações e consequências. Isso serviria tanto para motivar seus integrantes, mantendo o grupo coeso, como para apresentar-se externamente como uma organização com objetivos e valores bem definidos (Cf. GERGES, 2016, p. 90-3).

Em que pese ter Al-Zarqawi moldado um grupo que, inicialmente, apresentava reconhecido sucesso em suas campanhas insurgentes, logo uma sucessão de acontecimentos conduziu a Al-Qaeda no Iraque a importantes mudanças organizacionais e de liderança.

\subsection{O SURGIMENTO DO ESTADO ISLÂMICO DO IRAQUE}

Conforme se desenvolviam as atividades insurgentes no Iraque, crescia a disputa pelo poder dentre os grupos que a compunham. Em que pese estar em evidência a importância da Al-Qaeda no Iraque nesse cenário, os métodos por esta utilizados e os resultados de certas campanhas acabaram por desagradar a algumas lideranças tribais espalhadas pelo território iraquiano. Uma das questões que mais se destacaram nesse sentido foi o fato de ter Al-Zarqawi aceitado uma aliança com a Al-Qaeda Central, pois essa decisão, ainda que tenha garantido à organização uma maior capacidade operacional, maior visibilidade internacional e um número muito maior de seguidores, acabou por relegar a um segundo plano o caráter iraquiano do grupo. Esta questão, julgada de grande importância para muitos dos principais seguidores de Al-Zarqawi desde a formação do grupo, prejudicou o apoio e a relação política da Al-Qaeda no Iraque com as lideranças tribais do país. Isso fez com que o equilíbrio de forças e o apoio social por parte dos 
iraquianos não mais se apresentasse como antes. Do mesmo modo, essa nova realidade gerou profundo descontentamento entre a liderança do grupo e as massas que o seguiam. Concomitantemente, Al-Zarqawi passou a nutrir inimizade e desconfiança junto a diversas lideranças de outros grupos insurgentes, o que causou um notável aumento na quantidade de seus inimigos (Cf. PLEBANI, 2014, p. 8).

Em junho de 2006 Al-Zarqawi faleceu em decorrência de um ataque aéreo norte-americano. Segundo Andrea Plebani (2014, p. 9), a morte de Al-Zarqawi foi possível graças à infiltração de grupos inimigos à Al-Qaeda no Iraque, os quais passaram a explorar o enfraquecimento da relação de confiança entre o líder e seus seguidores. Ficando a Al-Qaeda no Iraque sem seu primeiro líder, a Al-Qaeda Central, na pessoa de Al-Zawahiri, denominou o egípcio Abu Hamza al Muhajir como o novo líder de sua franquia iraquiana. Aqui se deu um fato determinante para o futuro da ramificação da organização no Iraque, pois por ocasião da manifestação de Al-Zawahiri acerca do futuro e do engajamento da Al-Qaeda no Iraque junto à insurgência, concitou à organização que lá estabelecesse um Estado islâmico (Cf. PLEBANI, 2014, p. 7-9).

Entretanto, o que ocorreu alguns meses após a morte do líder foi a reunião das lideranças do Conselho de Combatentes, composto por sete grupos insurgentes jihadistas iraquianos, dentre os quais se sobressaía a própria Al-Qaeda no Iraque. A decisão desse Conselho foi a unificação do grupo que fora liderado por Al-Zarqawi com os insurgentes que compartilhavam de sua ideologia. Assim, anunciou-se em 13 de outubro de 2006 a formação do grupo denominado Estado Islâmico do Iraque, tendo por emir o iraquiano Abu Omar al-Baghdadi. Ademais, a liderança do Estado Islâmico do Iraque, apesar das mudanças promovidas e do novo nome adotado, manteve sua lealdade a Osama Bin Laden, ainda líder da Al-Qaeda Central. Por conseguinte, continuou, ao menos formalmente - ou ainda para fins de propaganda - fazendo parte deste grupo (Cf. GERGES, 2016, p. 93-4).

Estas questões podem manifestar a necessidade de o grupo se reposicionar em meio ao movimento insurgente no Iraque, o que denota o reconhecimento de que ainda dependia da colaboração e aceitação por parte de outros grupos atuantes em território iraquiano, assim como das diferentes comunidades que os citados grupos representavam. A influência do Estado Islâmico do Iraque junto à insurgência não foi motivo suficiente para fazer com que as lideranças tribais e comunitárias renunciassem ao controle de suas localidades e de seus integrantes - muitos dos quais integravam seus próprios grupos 
armados, compondo o já mencionado Conselho de Combatentes - o que incluía o acesso a recursos diversos e a rotas de comércio ilícito. Além disso, pode-se avaliar também que essa junção de forças pode ter se dado em função do reconhecimento por parte dos integrantes da Al-Qaeda no Iraque de que estes não poderiam competir com os demais grupos jihadistas que se encontravam em sua esfera de influência (Cf. GERGES, 2016, p. 137). O elemento sectário, importante característica das relações políticas do Iraque, uma vez mais se fez notar, revelando-se fundamental para as decisões a respeito da formação da organização, da nomeação da nova liderança, da nova denominação e dos rumos que tomariam o Estado Islâmico do Iraque. As divergências ideológico-religiosas entre o Estado Islâmico do Iraque e os integrantes dos demais grupos insurgentes, bem como as lideranças das mencionadas comunidades, também foram motivo de disputa política em meio à consolidação do novo grupo, já que as ações terroristas do Estado Islâmico do Iraque teriam violado várias normas, tradições e valores em voga há séculos na sociedade sunita iraquiana (Cf. PLEBANI, 2014, p. 9).

Então, o grupo experimentou uma grande perda de influência no Iraque, situação que piorou com os reveses experimentados em combate ao longo dos anos, uma vez que as tropas norte-americanas receberam importante reforço nesse período. Além disso, há que se frisar que a liderança do grupo em tela não trouxe qualquer mudança significativa ou inovação, o que pode estar relacionado ao declínio da organização, a qual continuou enfrentando contínuas derrotas em combates armados enquanto via seu prestígio diminuir por parte da Al-Qaeda Central. Este quadro certamente também afetou a imagem do Estado Islâmico do Iraque diante dos demais grupos insurgentes naquele país, deixando de ocupar a posição de destaque em que estivera um dia. Assim, em função do declínio das atividades da organização, bem como das crescentes dissenções entre a liderança do grupo para com a Al-Qaeda Central, em 2010 o Estado Islâmico do Iraque deixou de ser reconhecido por Bin Laden e Al-Zawahiri como parte de sua organização (Cf. WEISS e HASSAN, 2016, p. 91).

Nesse mesmo ano, os líderes do Estado Islâmico, Abu Ayyub al-Masri e Abu Omar al-Baghdadi, foram mortos por forças norte-americanas, o que, à primeira vista, parecia significar o fim da capacidade organizacional do Estado Islâmico do Iraque (PLEBANI, 2014, p. 10). As circunstâncias que caracterizaram a eliminação desses líderes, bem como o perfil do novo líder do Estado Islâmico do Iraque, viriam a alterar muitas de suas características organizacionais e as circunstâncias em que se encontrava o grupo. Uma nova e importante fase estava por iniciar. 


\subsubsection{A influência de Al-Baghdadi}

Abu Bakr al-Baghdadi, cujo nome real era Awwad Ibrahim Ali al-Badri alSamarrai, tornou-se líder da organização de maneira repentina, após os líderes anteriores terem sido mortos em razão de ataques realizados por tropas conjuntas dos Estados Unidos e do Iraque. Antes de ascender à liderança do grupo, já ocupara o terceiro cargo na hierarquia da organização. Seu perfil destoava do daqueles que o haviam antecedido, pois Al-Baghdadi era um acadêmico, professor de direito islâmico, tendo obtido seu doutorado em Jurisprudência Islâmica na instituição que hoje é denominada Universidade Islâmica de Bagdá. Não se tratava de um combatente experimentado, como os comandantes anteriores (Cf. GERGES, 2016, p. 131). Seu perfil, entretanto, condizia parcialmente com a grande maioria dos indivíduos que pertenciam à cúpula da liderança do grupo, pois também havia cumprido pena em centro de detenção do Oriente Médio (Cf. WARRICK, 2016, p. 243-4).

Como ocorreu com outros milhares de iraquianos sunitas, para Al-Baghdadi a intervenção ao Iraque de 2003 também foi um momento que o impulsionou à radicalização ideológico-religiosa. Dentro dessa visão, os Estados Unidos estariam entregando o Iraque, até então governado por uma cúpula sunita, aos os xiitas - ou, como se pode interpretar, ao principal patrocinador dos grupos xiitas no Oriente Médio, o Irã o que acabaria por significar a derrocada de toda a população sunita de suas condições sociais e econômicas no país. Portanto, Al-Baghdadi se juntou a um grande número de sunitas e passou a compor grupos insurgentes armados contra as forças estrangeiras e iraquianos xiitas, os quais eram tidos como colaboradores dos norte-americanos e, portanto, tidos como traidores. Nessa época, colaborou para com a fundação de um desses grupos insurgentes, denominado Jamaat Jaish Ahl al-Sunnah wal Jamaa. Ainda que AlBaghdadi fosse considerado pelas forças norte-americanas como uma peça sem importância na insurgência iraquiana, foi detido em 2004, permanecendo por poucos meses na prisão de Bucca, por oferecer baixo grau de ameaça. Contudo, durante o período em que permaneceu detido, Al-Baghdadi, juntamente com antigos oficiais baathistas, teve contato com indivíduos que o introduziram à ideologia salafista-jihadista. Gerges (2016, p. 130-3) aponta para o fato de que Al-Baghdadi foi um dos muitos indivíduos que não eram membros da Al-Qaeda, tampouco salafistas-jihadistas, que se tornaram 
extremistas em decorrência das experiências vividas dentro das prisões iraquianas. Experiências dessa natureza levaram muitos a integrar a Al-Qaeda no Iraque ou outros grupos militantes islâmicos posteriormente. De fato, no caso de Al-Baghdadi, foi justamente quando este deixou a prisão, em 2006, que ingressou ao Estado Islâmico do Iraque.

Já em 2010, com a morte do então líder do Estado Islâmico do Iraque, Abu Omar al Baghdadi, a organização procurava um novo líder, capaz de evitar a sua decadência. Para tanto, procuravam um indivíduo cujo perfil representasse autoridade religiosa e que também já tivesse obtido sucesso em assuntos de natureza estratégica. Nessa ocasião, Al-Baghdadi, detentor de vastos conhecimentos religiosos e tendo demonstrado suas capacidades de liderança ao longo dos anos, viria a ser escolhido como o novo líder do grupo (Cf. STERN e BERGER, 2015). Tendo iniciado sua jornada no Estado Islâmico desde o mais baixo escalão, Al-Baghdadi tornou-se um elemento carismático dentro do grupo, vindo a merecer a confiança de importantes figuras, inclusive do então líder, Omar al-Baghdadi (Cf. GERGES, 2016, p. 135-6). Alçado a tal posição, viria a se cercar de antigos oficiais militares e policiais que haviam servido ao regime baathista de Saddam Hussein. Dentre estes encontravam-se muitos dos responsáveis pela repressão à oposição política e sectária que vigorara nas décadas anteriores, o que denota que o entorno do líder estava habituado à brutalidade que caracterizara a manutenção do status quo durante o regime de Saddam, como indica Gerges (2016, p. 10). Observações semelhantes fazem também Stern e Berger (2015), os quais afirmam que os oficiais baathistas, muitos dos quais se tornaram conhecidos de AlBaghdadi na prisão de Camp Bucca, supriram a falta do Estado Islâmico do Iraque quanto a oficiais com conhecimentos militares e habilidade organizacional, os quais acabaram por compor uma rede de administradores e burocratas experientes. Colocam ainda que, na gestão de Al-Baghdadi, os baathistas tornaram-se uma parte criticamente importante do Estado Islâmico do Iraque.

Analisando-se a colocação de Gerges quanto ao papel do entourage de AlBaghdadi, mais especificamente no que diz respeito à instrumentalização da violência, percebe-se que de forma alguma a ideologia salafista-jihadista, à qual o Estado Islâmico adere, poderia ser considerada sinônimo do baathismo. Da mesma maneira, não podem ser ligados aos preceitos político-ideológicos similares, como tem sido mencionado por alguns analistas. Tal similaridade não se pode constatar, uma vez que os integrantes do partido Baath expressavam uma ideologia que se baseava principalmente no secularismo 
e no nacionalismo. Dessa forma, tem-se que o secularismo, em princípio, não seria compatível com a retórica apregoada pelo Estado Islâmico, a exemplo de todos os outros grupos que se postam como salafistas - ainda que não possuam no jihadismo militante uma de suas características. Para estes, o aspecto religioso é fundamental tanto para suas funções organizacionais internas como para a propagação ideológica em que se inserem. Daí se pode denotar que os antigos oficiais de Saddam Hussein também foram alvo de radicalização durante o período em que se encontraram presos em Camp Bucca ou em outras prisões, oportunidades em que foram introduzidos à ideologia salafista-jihadista. Nota-se um paralelo entre a "de-Baathificação" do governo iraquiano promovido pelos norte-americanos após a queda de Saddam Hussein, e o que Stern e Berger (2015) chamam de "baathificação" do Estado Islâmico do Iraque promovida por Al-Baghdadi, em um processo de aliança entre o salafismo-jihadismo e os ex-integrantes do governo iraquiano que haviam perdido seus empregos e status social.

Ao assumir a liderança do Estado Islâmico do Iraque em maio de 2010, AlBaghdadi teve de adotar medidas para reverter a situação em que a organização se encontrava após os diversos reveses militares e a morte de seus últimos líderes. Como aponta Andrea Plebani (2014, p. 10), Al-Baghdadi, com o intuito de reorganizar o grupo, inicialmente teve que expulsar os indivíduos que não lhe inspiravam confiança, de modo a reforçar os laços de lealdade e de compromisso entre a liderança e seus membros. Esta medida foi particularmente interessante, pois ao adotá-la Al-Baghdadi enfatizou os laços de união entre seus adeptos iraquianos e os estrangeiros, deixando claro que todos possuíam objetivos comuns e deveriam combater aqueles que não compartilhassem do mesmo objetivo. Esta medida, percebe-se, garantiu a necessária coesão para que a organização não se esfacelasse ainda mais. Deste modo, tendo corrigido graves problemas internos de cunho principalmente étnico, Al-Baghdadi pôde explorar duas condições que se observaram no Iraque naquele período. A primeira foi a crescente polarização do sistema sócio-político iraquiano, o que separava e diferenciava cada vez mais a população sunita dos curdos e dos xiitas, condição esta que mantinha a população sunita do Iraque em uma relação de interdependência em relação ao Estado Islâmico do Iraque, conforme este se solidificava como força sociopolítica dentro do sunismo. Já a segunda condição foi a retirada das forças militares norte-americanas que se encontravam estacionadas no Iraque, o que significou para o grupo de Al-Baghdadi uma diminuição, ainda que de forma gradual, de capacidade de oposição militar à sua expansão. Com as tropas americanas fora do país, poucos poderiam fazer oposição de fato às operações militares 
do Estado Islâmico do Iraque, o que se provou um importante facilitador da expansão física e territorial da organização (Cf. PLEBANI, 2014, p. 10-1).

Estes dois fatores observados à época da assunção do posto de líder do Estado Islâmico do Iraque por Al-Baghdadi podem ser vistos como uma janela de oportunidade para a organização. Al-Baghdadi provou, entretanto, ter tido visão estratégica o suficiente para tirar proveito do panorama com que se deparou. A referida polarização permitiu à Al-Qaeda no Iraque uma expansão ideológica nesse país e, logo, para além de suas fronteiras. Enquanto isso, a retirada dos norte-americanos daquele território viabilizou sua expansão física.

Já a questão do nacionalismo traz alguns elementos que devem ser avaliados com mais pormenor, uma vez que a liderança de Al-Baghdadi trouxe algumas mudanças à estrutura organizacional do Estado Islâmico, mormente no que se refere à administração do grupo e à forma de se manterem coesos seus integrantes. Dentre os elementos valorizados por Al-Baghdadi estava a "iraquização" do Estado Islâmico, numa tentativa de valorizar o elemento nacionalista dentro do grupo, o qual, em que pese ter envolvido muitos estrangeiros ao longo dos anos - incluindo seu primeiro líder - havia sido formado no Iraque e lá operava. Com relação a tal "iraquização", aliás, Andrea Plebani (2014, p. 8-10) também aponta que a liderança anterior do grupo já se preocupava com a valorização do aspecto nacionalista do grupo, pois percebera que esse teria sido um dos fatores que mais prejudicaram a relação de apoio político-ideológico a Al-Zarqawi. Essa característica pode ter mais relação com as necessidades operacionais do grupo do que com seus anunciados propósitos político-ideológicos. Note-se, a esse respeito, que o salafismo-jihadismo, via de regra, se insere em meio ao sunismo, o que excluiria a perspectiva nacionalista - numa visão referente a vínculos a um Estado formal - de suas características, pois a observância de tal ideologia ignora, em tese, a nacionalidade de seus simpatizantes. Os grupos salafistas, bem como aqueles adeptos do jihadismo, encontram-se espalhados por diversos países e em diferentes continentes, o que indica a irrelevância da nacionalidade dos seus adeptos em qualquer nível. A expansão de tais ideologias, aliás, só foi possível, e continua sendo observada, graças à aceitação e ao incentivo de um crescente número de adeptos das mais variadas nacionalidades frente aos seus objetivos, os quais, de certa maneira, acabam por ser muito similares aos do Estado Islâmico. Portanto, ao se analisar a influência dos assessores de Al-Baghdadi junto ao Estado Islâmico, o nacionalismo pode ser tido como um elemento trazido ao grupo pelos antigos integrantes do partido Baath, mas que teve um papel mais relevante somente no 
seio da organização, ou seja, funcionando mais como condição de coesão entre seus integrantes. Externamente, o elemento nacionalista não se fez observar, dada a confluência de inúmeros indivíduos das mais variadas nacionalidades, os quais jamais deixariam seus países para aderir a uma organização que priorizasse iraquianos em detrimento de estrangeiros. Ainda que num primeiro momento possa parecer que os antigos integrantes do partido Baath teriam se apossado do controle do Estado Islâmico, tem-se que, na realidade, foi esta organização salafista-jihadista que demonstrou a capacidade de atrair esses indivíduos à sua causa, a exemplo do que lograram fazer com integrantes dos mais variados grupos, comunidades e países.

A partir de 2010, o Estado Islâmico do Iraque aumentou significativamente o nível de violência durante sua expansão, superando os registros do ano de 2008, que foi marcado por inúmeros atentados terroristas com a utilização de artefatos explosivos por todo o país. Tais eventos se tornaram um indicativo da nova forma de atuação da liderança do grupo. Entretanto, em 2011 Al-Baghdadi percebeu na vizinha Síria uma grande oportunidade para o desenvolvimento do Estado Islâmico do Iraque, em razão do desenvolvimento dos conflitos sociais decorrentes da Primavera Árabe naquele país (Cf. WARRICK, 2016, p. 244). O envolvimento da comunidade sunita síria com as disputas políticas naquele país lhe ofertavam ótimas condições para que a organização salafistajihadista expandisse suas operações. Al-Baghdadi aproveitou-se então da proximidade de alguns de seus redutos próximos à fronteira com a Síria para enviar ao país vizinho um grupo de experimentados combatentes, liderados por Abu Muhammad al-Julani, com o fito de que lá criassem um grupo insurgente. Mais tarde, tal grupo viria a se denominar Jabhat al-Nusra ${ }^{21}$ (Cf. REILLY, 2016, p. 157). Esta organização, mais do que ter provado sua ampla capacidade de liderar a insurgência contra o governo da Síria, logo se tornou um dos mais importantes em atuação naquele cenário (Cf. PLEBANI, 2014, p. 10). A partir deste ponto torna-se necessário o estudo das condições da Síria nesse momento, para que se possam então avaliar as questões referentes ao Estado Islâmico do Iraque.

\footnotetext{
${ }^{21}$ Grupo salafista-jihadista operante na Síria chamado Jabhah Al-Nusrah li Ahl al-Sham (em árabe, "Frente de Assistência para o Povo da Síria"), mais comumente denominada de Frente Al-Nusra. Composto inicialmente de militantes do Estado Islâmico do Iraque para combater o governo de Al-Assad na Síria. Reconhecido formalmente como Al-Qaeda na Síria, uma vez que quando de sua formação o próprio Estado Islâmico do Iraque se colocava como subserviente à Al-Qaeda Central (Cf. GERGES, 2016, p. 16).
} 


\section{A SÍRIA CONTEMPORÂNEA}

\subsection{QUESTÕES DE ECONOMIA, POLÍTICA E SOCIEDADE}

Até o ano 2000 a Síria era governada por Hafez Al-Assad, sendo que o Estado controlava praticamente toda a economia nacional. A agricultura se destacava dentre os países da região, e um importante aspecto que a viabiliza em meio a grandes extensões desérticas é a existência do rio Eufrates, cujas águas correm em direção ao Iraque. Esse rio possibilitou a construção de uma grande represa com com o objetivo de formar um importante reservatório, denominado de Lago Assad. Desde então, tendo falecido o presidente sírio, seu filho e sucessor Bashar assumiu o governo, trazendo significativas mudanças à administração e à economia do país. Inicia-se então alguma liberalização econômica, passando-se à formação de bancos que viriam a contar com incentivos governamentais e investimentos de diferentes fontes. A própria bolsa de valores da Síria começa suas atividades nessa época (Cf. VISENTINI, 2014, p. 204).

O novo presidente visava modernizar e desenvolver o país, dando ênfase à economia em detrimento de questões especificamente políticas. Assim, deu-se grande importância à transparência e à responsabilidade nos gastos estatais, bem como à diminuição da burocracia governamental e ao combate à corrupção. Tais medidas visavam inserir a Síria em uma economia de mercado de forma competitiva (Cf. YASSIN-KASSAB e AL-SHAMI, 2016, p. 16).

Entretanto, no campo político ocorreram importantes acontecimentos que também pesariam no desenvolvimento do país. Nesta esfera, um dos acontecimentos mais importantes foi a retirada das tropas sírias que se encontravam no Líbano desde o início da guerra civil libanesa, em 1970, trazendo-se de volta ao território sírio grande contingente militar. Outro fato relevante na esfera geopolítica foi o início da imposição de sanções econômicas por parte da comunidade internacional, tendo à frente os Estados Unidos, em razão da estreita relação e do suposto financiamento recebido pela Síria advindos de aliados xiitas, principalmente o Irã e a organização Hezbollah (Cf. VISENTINI, 2014, p. 204). Nota-se, portanto, que justamente num período em que o governo de Bashar Al-Assad procurava dar maior abertura à economia síria, com o objetivo de ganhar maior fôlego durante a inserção de seu país no mercado internacional, 
o país recebeu duro golpe em sua economia, na forma de sanções internacionais. Se deixar de ter relações comerciais com o governo norte americano já evitaria a evolução econômica síria, enfrentar tal tipo de sanções acaba por causar enorme impacto para a expansão econômica na dimensão supra regional. Ou seja, mesmo que o governo declarasse priorizar a economia ante a política, na prática percebeu-se que o impacto das questões políticas - advindas, mais uma vez, de motivos ideológico-religiosos e sectários, dada a preponderância do xiismo no que se refere às relações diplomáticas da Síria no cenário regional - não deixariam de se sobrepor à agenda econômica. Nesse caso, preferiu o governo Assad enfrentar o recesso econômico a prejudicar suas relações políticas junto a seus financiadores xiitas.

Bashar Al-Assad deixou claro, no transcorrer dos anos em que esteve à frente do governo sem se deparar com grandes contratempos de ordem política e econômica, que não estava comprometido com a abertura e a com a liberalização da Síria, conforme mencionara em seus discursos como a "Primavera de Damasco", o que lhe rendera grande popularidade entre a população mais jovem. Al-Assad estabeleceu seu regime, como enxergam Raymond Hinnebusch (2019, p. 32) e James Reilly (2016, p. 150), sobre os conceitos da asabiyya, para consolidar os vínculos de confiança com seus apoiadores. Esses vínculos, por sua vez, garantiam acesso ao centro do poder, mantendo uma engrenagem histórica de relação de patriarcado construída ao longo dos séculos na cultura árabe. Tais movimentos garantiram, na realidade, uma crescente concentração de poder a Al-Assad e seus aliados, tendo o presidente colocado em prática uma fusão entre o aparelho de Estado - no qual representantes do partido Baath tinham extensa participação - e as forças armadas. Estas condições permitiram ao regime reprimir eventuais revoltas de maneira violenta, evitando maiores consequências para o governo. Por conseguinte, tal nível de repressão também passava ao largo da opinião pública internacional, uma vez que o governo de Assad virara as costas à política externa durante muito tempo. Ficou evidente à grande maioria da população síria que suas perspectivas de reformas econômicas, de ampliação de liberdades civis e outras melhorias estruturais - as quais, esperava-se, lhes trariam melhores condições de vida - estavam na verdade longe de se concretizar (Cf. SILVA, 2016, p. 162-4).

A população síria, segundo Peter Demant, tem por marcante característica a divisão de sua população entre diferentes comunidades com base em três questões: étnicas - considerando-se a presença de árabes, de curdos e outras minorias étnicas -; econômicas - entre os habitantes de centros urbanos e aqueles que vivem em áreas rurais - e religiosas 
- dada a existência de sunitas, os quais constituem a classe média das principais urbes e outras correntes religiosas que predominam no campo, como drusos, cristãos e ismaelitas (2004, p. 218). Ainda hoje estão patentes os efeitos e consequências de problemas oriundos de antigas disputas entre tais comunidades, as quais acabaram por ser ora reprimidas, ora exploradas, ou ainda, em alguns casos, potencializadas pelo governo baathista. A despeito dos problemas sociais, econômicos e políticos advindos dessa configuração, não houve instituição dentre os sírios que tenha tido sucesso na alteração da ordem das coisas, muito provavelmente por temer a repressão do governo ou as prováveis condições caóticas que se seguiriam à subversão do establishment naquele país. Uma revolução ou a promoção de grandes alterações ao sistema constituído na Síria, há que se entender, poderia não parecer uma empreitada segura a muitos grupos sociais, levando-se em conta a experiência recentemente observada no Iraque - onde o partido Baath também estivera no poder havia décadas -, onde a subversão dos status quo por parte da insurgência sunita acabara levando o país a uma situação caótica, dragando as condições de vida de grande parte da sua população a uma situação calamitosa (Cf. GUIDÈRE, 2012, p. 173).

\subsection{RELIGIÃO NA SÍRIA}

Da população de cerca de 17 milhões de habitantes da Síria, por volta de $10 \%$ são cristãos, enquanto de 85 a $90 \%$ são muçulmanos. Destes últimos, cerca de $75 \%$ são adeptos do sunismo, e $13 \%$ a $15 \%$ declaram-se alauítas. No intuito de melhor posicionar tal grupo dentro do universo de vertentes islâmicas, deve-se perceber que os alauítas são originários do grupo de seguidores do décimo primeiro imã na linhagem xiita, Hasan al'Askari, e seu pupilo Ibn Nusair. Organizaram-se no século X, principalmente ao redor da cidade de Alepo, na Síria, constituindo-se assim em um grupo muçulmano de origem xiita, cujas crenças e práticas religiosas são mantidas em relativo segredo. Neste ponto há que se destacar que o grupo alauíta, ainda que perfaça tão pequena porção dentre os dentre os sírios e dentre os muçulmanos de modo geral, possui atualmente grande relevância política na Síria, já que o presidente Bashar Al-Assad pertence a esse grupo. A proximidade entre os alauítas e os xiitas do duodécimo (vertente iraniana e majoritária do xiismo) seria explorada politicamente pelo governo de Al-Assad, pois, em 1973, somente três anos após a tomada do poder pelo alauíta Hafez Al-Assad (pai de Bashar), tal 
proximidade foi reiterada oficialmente por líderes religiosos sírios (Cf. HALAWI e GHAZZAL, 2004, p. 103). Isto pode ser visto como um importante posicionamento político e estratégico por parte do governo, pois tal colocação gera reconhecimento e consequente legitimidade aos alauítas em meio à comunidade islâmica, traçando-se, teoricamente, uma linha de relação junto aos líderes xiitas de outros países. Percebe-se, daí, que tal declaração, ainda que no campo da religião, acaba por colocar o regime sírio na esfera de influência do regime iraniano, importante vetor do xiismo no mundo islâmico e poderoso ator político no Oriente Médio.

As principais figuras políticas sírias, bem como os dirigentes das mais importantes instituições e ocupantes de posições-chave no governo Assad também são alauítas (Cf. LAWSON e ST JOHN, 2004, p. 2130). Na realidade, representantes desse grupo já chegavam a importantes posições sociais desde o fim do mandato francês na Síria, tendo-se intensificado tal incremento durante o período em que o partido Baath vigorara. Contudo, foi com o governo Assad que tal grupo de fato se consolidou no poder (Cf. HALAWI e GHAZZAL, 2004, p. 103-4). Para tanto, foram necessárias algumas manobras de caráter notadamente político por parte de Hafez Al-Assad em função da exigência constitucional síria, na qual somente um muçulmano pode se tornar presidente. Assim, o novo governante, ciente de que na visão sunita - ou seja, da maioria dos sírios - os alauítas não seriam considerados muçulmanos, logrou obter de juristas sírios, tanto representantes do xiismo quanto do sunismo, fatwas no sentido de que os alauítas devessem ser reconhecidos como muçulmanos de tradição xiita.

De fato, hábil manejo político foi demonstrado por Al-Assad após a publicização de tais fatwas, frente à grande contestação de seu conteúdo. O presidente, buscando legitimar o posicionamento dos religiosos e sua posição de liderança, organizou matrimônios entre alauítas e sunitas, dentre os quais cidadãos sauditas, numa manobra política formidável, buscando assim apoio e legitimidade junto à Arábia Saudita, tida como a maior representante do sunismo. Assim, além de obter apoio sunita dentro e fora de suas fronteiras, o governo sírio acabou por também acenar para o ocidente, uma vez que o governo saudita é grande aliado dos Estados Unidos no Oriente Médio. Como explana Mathieu Guidère (2012, p. 170), de uma vez por todas Hafez Al-Assad legitimou oficialmente a inserção dos alauítas à ummah, a sociedade islâmica, assim garantindo não só sua permanência no poder, mas também abrindo caminho para alçar a funções governamentais outras figuras alauítas. Justamente em razão de tal condição, a Síria é o único lugar em que os alauítas possuem projeção política atualmente. Num passado mais 
recente, já no início dos anos 2000, mesmo diante desse cenário, Bashar Al-Assad, seguindo os passos de seu pai, acaba por se aliar aos governos e organizações xiitas, de maneira a obter apoio político e subsequentes vantagens do Irã e aliados deste.

Retornando-se à questão do reconhecimento da situação dos alauítas como muçulmanos, há que se perceber que o já mencionado jurista sunita Ibn Taymiyya - cuja doutrina serviu de base para a ideologia disseminada por Al-Maqdisi, mentor de AlZarqawi - já considerava aos alauítas como hereges, mencionando que os mesmos deveriam ser combatidos como uma seita desviante. Ou seja, a origem do presidente sírio Bashar Al-Assad se apresenta, dentro da visão político-religiosa da qual compartilhavam tanto Al-Zarqawi quanto seu sucessor, Abu Bakr Al-Baghdadi, como um grande motivo para promover a sua destituição do poder.

O panorama da sociedade síria apresenta, por conseguinte, uma peculiaridade em relação ao que se observa nos outros países islâmicos, por não estarem os grupos sunita ou xiita na cúpula do poder. Na realidade, a aliança entre a Síria de Assad e o Irã incluindo-se o apoio militar do Hezbollah - proporcionaram à Síria uma melhor condição política regional, passando a estar em posição de maior equilíbrio em relação aos demais poderes do Oriente Médio (Cf. SOTTIMANO, 2019, p. 161). Em momentos de extrema necessidade, como se veria durante os desdobramentos da guerra civil síria atualmente, o apoio externo seria vital à manutenção da família Assad no poder, como no caso do emprego de grupos armados do Hezbollah em defesa do regime sírio, evidenciando o amplo apoio iraniano ao líder sírio.

A sustentação da família Assad no poder por já quase cinquenta anos, aliás, se deve em grande medida ao seu posicionamento político-religioso tanto no campo interno quanto no externo. A configuração da sociedade síria, que se pauta, em grande medida, na dispersão étnica e cultural e no domínio das elites pela minoria alauíta - ainda que possuindo uma maioria sunita - mostrou-se favorável à manutenção do regime da família Assad no governo da Síria (Cf. SILVA, 2016, p. 162). Tendo garantido apoio internamente por parte de outras minorias étnico-religiosas além da alauíta, como no caso das comunidades drusa, armênia, circassiana e grega, o apoio externo foi garantido devido à aproximação a países que possuem nessas comunidades representações sociais importantes. 


\subsection{A PRIMAVERA ÁRABE NA SÍRIA}

Outro evento de grande relevância trata-se da Primavera Árabe, uma sequência de protestos de cunho político envolvendo grande parte das populações de diversos países do norte africano e do Oriente Médio. Iniciando-se com protestos contra o governo da Tunísia em dezembro de 2010, logo as reivindicações contra regimes ditatoriais se tornaram uma onda revolucionária crescente nas regiões supramencionadas. Em janeiro do ano seguinte iniciaram-se protestos na Argélia, seguindo-se então Líbia, Egito, Iêmen, Síria, Bahrein e o próprio Iraque (DABASHI, 2012, p. 18-9). Segundo Torelli e Varvelli, essa sequência de eventos, que provocou grandes mudanças políticas nas regiões, acabou por propiciar a emergência de novos movimentos insurgentes nessas áreas geográficas (2014, p. 45).

Apesar do relativo sucesso na Tunísia em se substituir um regime governamental sem grandes incidentes violentos, no Egito os acontecimentos começaram a registrar maior violência. Contudo, foi na Síria que a violência do regime recaiu mais fortemente sobre a população, fazendo com que parte da insurgência emigrasse e outra se articulasse, de maneira a formar grupos armados. Em um curto espaço de tempo a maior parte do país se encontrou imerso em confrontos armados que originariam um conflito internacional, cujas consequências, mais tarde se veria, se tornariam globais. Aliás, como a Síria se encontra em uma posição geográfica que constantemente se encontra invadida por diferentes poderes internacionais, é natural que a política externa acabe por se sobrepor aos assuntos internos do Estado (Cf. SOTTIMANO, 2019, p. 162). As consequências da Primavera Árabe serão mais pormenorizadamente avaliadas adiante, uma vez que na Síria se observou a onda de protestos de maior relevância, além de possuir ligação direta com o tema objeto de estudo.

Como ressalta Mathieu Guidère em sua avaliação do contexto sírio imediatamente antes do advento da Primavera Árabe no país sob lentes,

os muçulmanos sunitas, maioritários no país, estão fartos do domínio dos alauítas minoritários e nomeadamente das negociatas do clã no poder. Na ausência de qualquer perspectiva de mudança política, entregaram-se a uma prática religiosa fortemente identitária. Na Síria de reputação laica, já não se contam as mulheres com véus e os círculos religiosos, de tal maneira eles se multiplicaram. (...) Consciente da evolução do mundo, o movimento da Irmandade Muçulmana sírio abandonou oficialmente a violência e voltou-se para a estratégia de 
islamização a partir de baixo, preconizada pelos irmãos egípcios. A maioria dos seus membros são modernistas preparados para jogar o jogo democrático, no modelo turco, na esperança de tomar um dia o poder através das urnas. (...) A não ser que o regime do partido Baath adote, para a sua própria sobrevivência, a estratégia do caos e da guerra civil (2012, p. 175).

Ou seja, constata-se que na Síria, ao mesmo tempo em que havia diversos motivos para que a população sunita procurasse meios para a deposição do regime de Bashar Al-Assad, este também considerava a utilização da estratégia de se provocar o caos através da violência generalizada visando garantir a manutenção do regime no poder (ou, no caso da população sunita, a conquista do poder) através das armas, como já fora feito anteriormente em diversas ocasiões, com relativo sucesso. Menciona o autor a relevância da Irmandade Muçulmana, uma vez que tal organização era, até à época da eclosão da Primavera Árabe, a responsável pelo principal movimento islamista em território sírio, já tendo demonstrado sua importância quando dos eventos de igual natureza no Egito pouco tempo antes. Entretanto, percebe-se que tal organização não exerceu papel preponderante junto à população sunita, por motivos que se podem compreender ao se recordar a maneira como o regime Assad havia lidado com revoltas sunitas ao longo dos anos. Quando do início da luta armada da Irmandade Muçulmana contra o regime Baath no final da década de 1970, o governo Assad deu início a uma reação das mais violentas no Oriente Médio, sendo responsável por massacres em diversas cidades, incluindo-se as de Alepo, Palmira e Hama. No caso desta última, foram bombardeados por peças de artilharia diversos de seus bairros, causando cerca de quinze mil mortos (Cf. GUIDÈRE, 2012, p. 174). Ainda que tais fatos tenham passado desapercebidos por grande parte da mídia, já que no centro das atenções se mantinha a Guerra do Líbano, a reação do governo sírio foi, nas palavras de Robin Wright, "o mais mortífero ato isolado por um governo árabe contra o seu próprio povo no Oriente Médio moderno" (2008, p. 224).

Isto quer dizer que, de fato, os islamistas sunitas, representados principalmente pela Irmandade Muçulmana, tinham plena consciência de que nova luta armada levaria o regime de Assad a adotar, muito provavelmente, extensa e violenta repressão, como já fizera antes. Ou seja, o início de uma eventual insurgência contra o governo em questão traria grande risco à população sunita síria, incluindo-se civis, como os exemplos mencionados deixam claro. No entanto, a configuração sócio-política na Síria trazia diversos elementos que potencializariam uma eventual revolta popular, na 
esteira dos acontecimentos recentemente observados no norte da África, como a falta de liberdades civis, grande repressão policial, a existência de um partido único, meios de comunicação vigiados, corrupção das elites, pobreza e acentuada desigualdade (Cf. GUIDÈRE, 2012, p. 175; YASSIN-KASSAB e AL-SHAMI, 2016, p. 35). Fazia-se patente a decepção da população com a situação social e com a condução da política no país, após uma década de reformas que acabaram por agravar continuamente os problemas da maioria da população síria, que apresentava, dentre outros graves problemas sociais, a exemplo de seus vizinhos iraquianos, enorme desigualdade social. Acentuava-se cada vez mais, nesse processo, a diferença entre as classes mais ricas e as mais pobres da Síria (Cf. STARR, 2012, p. 112-3; COSTA, 2016, p. 91).

A Síria experimentava, portanto, acentuadas frustrações dentre as várias camadas de sua sociedade, muitas das quais careciam de representação política. $O$ desemprego, a pobreza, a falta de liberdade de expressão e o regime ditatorial eram evidentes e não mais podiam ser tolerados (Cf. SILVA, 2016, p. 161). As condições de sua população, contudo, vinham piorando notadamente em razão de fatores externos, dentre os quais se podem apontar, principalmente, as diversas mudanças sociais que vinham sendo implementadas em diferentes países da região, aos problemas econômicos enfrentados pela Síria frente à crescente globalização e às políticas externas praticadas pelo governo iraniano - cujas políticas que beneficiavam os xiitas e alauítas acabavam por excluir de certo modo a população sunita. Ademais, o sempre presente conflito entre a Síria e Israel - fator também fustigado pelo regime do Irã, acentuadamente hostil a Israel - também acabava por motivar o governo Assad a manter a estratégia de "resistência e obstrução" no cenário internacional, custosa politicamente ao Estado, e economicamente à população (Cf. GUIDÈRE, 2012, p. 176). As condições de vida no país, consequentemente, encontravam-se em um ponto em que o povo sírio não via mais possibilidades de melhoria a não ser que houvesse ruptura do status quo.

Os benefícios das revoltas ocorridas nos demais países árabes, afinal, assomavam-se no horizonte como certo grau de motivação para se lançarem contra o regime Assad. Pode-se notar que o desenrolar dos acontecimentos históricos nos vizinhos árabes apresentavam-se, ao povo sírio, sobretudo a sua parcela sunita, uma possibilidade de mudança e melhoria. A história moderna da Síria trazia registros de grande violência por parte do governo nas vezes em que se havia procurado algum tipo de subversão. Entretanto, a necessidade de mudança e a esperança por melhorias definitivas, como os 
eventos vindouros demonstrariam, acabariam por se sobrepor ao receio da violenta repressão.

Foi no início do ano de 2011 que se registraram as primeiras revoltas populares na Síria, dando-se início à Primavera Árabe neste país, em sequência aos levantes já ocorridos na Tunísia, na Líbia e no Egito (Cf. YASSIN-KASSAB e ALSHAMI, 2016, p. 36). O fato de terem os primeiros atos de revolta se dado em Deraa e em Lataquia, justamente em regiões onde predomina a parcela da população alauíta, é indicativo da relevância da participação sunita desde o início do levante contra o governo de Assad. Há ainda que se reparar que este, ao contar com o apoio tanto do Irã quanto da Rússia, gozou de certa proteção contra eventuais providências efetivas por parte da comunidade internacional, mantendo assim condições de melhor coibir a revolta que se iniciava.

Os protestos levados a cabo por tunisianos e egípcios no início da Primavera Árabe tiveram grande influência sobre o povo sírio. Na acepção de Christopher Phillips (2012, p. 38-9), a sensação de empoderamento causada aos sírios ficou explicitada pela imitação de slogans e de protestos. Ademais, a violenta reação por parte do governo também foi um fato importante para a evolução dos conflitos, pois Bashar Al-Assad, seguindo o exemplo de como seu pai agira perante os protestos das décadas de setenta e oitenta, deixou claro que o governo se utilizaria da violência para frear o levante civil. Como consequência, a oposição ao governo se tornou ainda mais radical, passando a também adotar a violência desmedida contra os representantes do regime.

Dada a importância e a centralidade da Síria para o Oriente Médio, o movimento evoluiu de forma bastante acelerada. Como expõe James A. Reilly (2016, p. 156-7), os atores estrangeiros logo passaram a demonstrar seus interesses quanto ao que ocorria em território sírio, seja a favor ou contra o governo constituído. A dinâmica da intervenção externa ao mesmo tempo reforçou a unicidade de propósito das forças próAssad e também dividiu ainda mais uma oposição que já se encontrava deveras fracionada. Os elementos que se constituíam no núcleo do regime de Assad - ou seja, as forças armadas, os funcionários de alto escalão e as milícias civis - tinham plena consciência de que teriam de se manter unidos em quaisquer circunstâncias, uma vez que não conseguiriam apoio de outros grupos dentro da própria Síria. Desse modo, o apoio russo e iraniano reforçou a determinação do regime de Assad em combater a oposição a 
qualquer custo. Era inevitável, dentro dessa perspectiva, que a Primavera Árabe na Síria evoluísse para um conflito supranacional.

Segundo Charles Lister (2015), os levantes que caracterizaram a Primavera Árabe na Síria podem ser divididos, em princípio, em três fases, em função das diferentes condições e grupos que se envolveram. A primeira delas, tendo se iniciado no mês de fevereiro de 2011, envolveu somente protestos não-violentos organizados por ativistas ligados a movimentos em prol de direitos civis, principalmente na capital, Damasco, e nos principais conglomerados urbanos da Síria. Os manifestantes, propunham reformas políticas ao governo que foram rejeitados categoricamente pelos líderes do movimento de oposição a Assad (Cf. LAWSON, 2018, p. 92). A esta altura, o regime de Assad já passa a se valer tanto da violência quanto da ampla divulgação propagandística em meio à população, principalmente com relação aos curdos, no intuito de diminuir o ímpeto violento das manifestações (Cf. REY, 2018, p. 310).

A segunda fase da insurgência síria, iniciando-se em novembro do mesmo ano, se tratou, basicamente, de uma guerra civil total, envolvendo opositores e apoiadores do partido Baath (LISTER, 2015). Já nesta fase se formaram grupos que estabeleceriam a disputa de forças que se observaria durante o desenrolar dos conflitos no país nos anos seguintes. Neste contexto, militantes contra o regime de Al-Assad formaram diversos grupos armados, muitos dos quais viriam a se juntar ao Exército Sírio Livre - composto majoritariamente por antigos militares das forças armadas -, ainda que mantivessem grande autonomia operacional. Já o Partido dos Trabalhadores do Curdistão, sediado no Iraque, juntou-se ao Partido da União Democrática para formarem milícias próprias, denominadas Unidades de Proteção Popular, atuantes nos redutos curdos do nordeste sírio. Os turcomenos, por sua vez, organizaram-se em diferentes grupos paramilitares atuantes principalmente na região da Lataquia (Cf. LAWSON, 2018, p. 92). Além do aspecto multifacetado do conflito, é importante enfatizar que nesta fase o mesmo já se tornara internacional, tendo forças financiadas pelo governo iraniano passado a integrar o cenário, notadamente a Força $A l-Q u d s^{22}$ e o grupo libanês Hezbollah, apoiando as unidades de elite do exército sírio (Cf. KAUSCH, 2015, p. 128; LAPIDUS, 2014, p. 879)

${ }^{22}$ Do persa “Jerusalém”. Unidade especial do Corpo de Guardas Revolucionários do Irã, responsável por operações no exterior (Cf. KAUSCH, 2015, p. 39). 
Ou seja, já se podia perceber a intervenção do Irã de forma a colaborar para com a defesa do regime de Bashar Al-Assad.

A terceira fase da guerra civil síria teria início no final de 2012, a partir de quando se percebeu uma reconfiguração dos grupos insurgentes, constituindo-se uma unificação de diversos desses grupos, surgindo então a Coalizão Nacional de Forças Sírias Revolucionárias e de Oposição (LISTER, 2015). Note-se que tal coalizão inclui grupos ligados aos fundamentalistas islâmicos da Irmandade Muçulmana. É a partir daí que se deu uma importante reorganização das milícias islamistas radicais, as quais logo se tornaram força predominante no âmbito da insurgência contra o governo de Al-Assad (Cf. HOLLIDAY, 2012; LUND, 2012). O alto grau de violência que caracterizou principalmente esta fase dos combates em meio à Primavera Árabe contribuiu para com que a população rural do interior da Síria também se integrasse, de forma significativa, a grupos jihadistas para lutar contra o governo de Assad. É neste cenário que se despontou a Frente Jabhat al-Nusra. Tal dinâmica, aliada à inserção cada vez maior de grupos milicianos estrangeiros à Síria, foi vital para o empoderamento de grupos jihadistas justamente como a Jabhat al-Nusra exemplifica -, o que veio a desequilibrar ainda mais o jogo de poder em desfavor do governo sírio (Cf. HINNEBUSCH, 2019, p. 45). Esse grupo recém-formado destacou-se não só pelos seguidos sucessos que alcançou durante os combates contra as forças regulares do regime sírio, mas principalmente pela utilização sistemática de atentados suicidas à bomba. Ademais, essa organização também se caracterizava por um acentuado antagonismo com relação às populações alauítas, ismaelitas e xiitas da própria Síria (Cf. LAWSON, 2018, p. 92-3).

A ascensão da Frente Al-Nusra, como visto acima, se apresentou ao grupo liderado por Al-Baghdadi, na ocasião denominado Estado Islâmico do Iraque, como uma janela de oportunidade. Isto pode se relacionar tanto à situação de caos advindo da instabilidade política e da consequente disputa violenta pelo poder na Síria, como à existência de grupos que compartilhavam de ideologia e de métodos de atuação similares aos do grupo de Al-Baghdadi. A influência da ideologia fundamentalista da Irmandade Muçulmana junto àqueles grupos insurgentes já se desenhava como uma questão que lhes era positiva, mas a ascensão da Frente Al-Nusra em meio aos demais grupos insurgentes destacou-se como uma configuração deveras positiva para o Estado Islâmico do Iraque. Esta situação demonstra ainda a clara a relevância da Al-Nusra em meio à insurgência síria, ponto importante para a estratégia de expansão do Estado Islâmico do Iraque dentro do Oriente Médio. Pode-se determinar, portanto, avaliando-se os elementos aqui 
expostos, que os conflitos sectários envolvendo islamistas radicais, o Exército Sírio Livre e as emergentes milícias étnico-sectárias na Síria estão diretamente ligadas ao surgimento do Estado Islâmico do Iraque e da Síria, cujas inovações - no que diz respeito à atuação em meio ao conflito armado - significou o ápice da violência causada por organizações não-estatais em meio à guerra civil síria (Cf. LAWSON, 2018, p. 92-3; REILLY, 2016, p. 152).

No caso do conflito que despontava na Síria, a questão religiosa teve papel importante no que se refere à política externa dos Estados atuantes, mais especificamente por se constituir o governo de Bashar Al-Assad em representante do xiismo, o que o torna, indubitavelmente, aliado do governo fundamentalista do Irã. Essa indica a influência xiita iraniana junto a outros Estados do Oriente Médio, o que caracteriza o plano de consolidação do Irã como potência regional. Como estabelece Visentini (2014, p. 254), dentro da política regional iraniana a Síria exerce papel importantíssimo, vindo a funcionar como um ponto de apoio para ação e movimentação de duas organizações que têm no governo iraniano seus principais apoiadores e financiadores: o Hezbollah, para suas atividades no território libanês, e o Hamas, com suas atividades junto à Palestina. Por isso, conforme a situação política e econômica da Síria foi se deteriorando ao longo da guerra civil, apresentou-se a países adversários do Irã uma grande oportunidade de se derrubar o governo sírio, o que facultaria romper o eixo de influência iraniana em meio no Oriente Médio. Como consequência, tanto o Qatar como a Arábia Saudita, estados sunitas, logo passaram a financiar a atividade armada de grupos insurgentes sírios. $\mathrm{O}$ importante auxílio externo ao conflito que se desenvolvia na Síria tornou o país um grande atrativo a muçulmanos seguidores do fundamentalismo islâmico, fato que permitiu o intenso crescimento da Frente Al-Nusra, organização que se valia do status de membro da Al-Qaeda naquele país. Consequentemente, o regime do Irã também reforçou sua ajuda bélica ao governo sírio, tendo empenhado, a contar de junho de 2013, o Hezbollah para lutar contra a insurgência na Síria. Assim, tal conflito se tornou, na prática, uma guerra por procuração, ou seja, envolvendo grupos controlados por diferentes Estados para promoverem suas políticas externas (Cf. VISENTINI, 2014, p. 254-5).

Assim, percebe-se que o envolvimento iraniano no conflito acabou por provocar um recrudescimento dos combates, uma vez que o regime persa inseriu no cenário sírio importante volume de material bélico e de militares de alta capacidade operativa, especialmente treinados para interceder em prol do governo de Teerã em territórios estrangeiros. Tal envolvimento, por conseguinte, apresenta-se como forte 
motivo para que as milícias sunitas se unissem, uma vez que o principal motivo de ter o Hezbollah e a Força Al-Quds adentrado ao conflito foi o caráter sectário, dado o apoio do Irã xiita ao regime de Bashar Al-Assad, alauíta. A Frente Al-Nusra, como se percebe, despontou em meio aos demais grupos insurgentes por ter se mostrado em melhores condições de frear o avanço das forças pró-Assad, notadamente mais bem organizadas e estruturadas. É nesse panorama que a Frente Al-Nusra passa a se utilizar do terrorismo como instrumento de intimidação, demonstrando tanto aos seus adversários quanto a seus integrantes que estavam dispostos a cometer qualquer sacrifício pelos objetivos do grupo. Ademais, a utilização de tal instrumento aponta para a utilização de uma estratégia, em meio à guerra civil, em que somente a violência seria utilizada, afastando-se a possibilidade de qualquer tipo de entendimento ou negociação com xiitas, curdos ou alauítas.

O fato de as maiores potências do Oriente Médio não intervirem junto aos violentos conflitos em território sírio foi um dos fatores que contribuíram para com a manutenção da violência por tanto tempo. Segundo Silva (2016, p. 162), o fator econômico pode ser apontado como a real motivação para que a comunidade internacional não houvesse interferido direta e efetivamente na guerra civil síria, uma vez que tal território não ofereceria grandes atrativos econômicos, ao contrário do que se ocorrera no caso da Líbia pouco tempo antes. No caso deste país, também palco de manifestações populares pela democracia seguidos de violentos confrontos entre facções populares armadas, não tardou se dar interferência de diferentes países que visavam “conter a proliferação da violência.” Nesse ponto de vista, a Síria - bastante díspar em relação à Líbia no que diz respeito ao petróleo, por exemplo, cuja produção a coloca dentre os principais produtores desse tipo de combustível fóssil em todo o globo - pouco teria a oferecer economicamente a outros regimes políticos, dada a escassez de atrativos econômicos que viabilizassem uma exploração dessa natureza em um curto prazo (Cf. SILVA, 2016, p. 162). Dentro dessa lógica, os gastos militares necessários a uma intervenção nos conflitos que se desenrolavam na Síria - seja a favor do regime ou dos grupos insurgentes - não se justificariam economicamente.

Além disso, outra questão também pode ser apresentada como relevante à não intervenção internacional desde o início dos conflitos na Síria. O fato de o regime de Assad compor o eixo formado junto ao Irã e ao Hezbollah também coloca enorme pressão política sobre qualquer Estado que queira interpor-se às demandas do governo sírio. Uma intervenção desse tipo traria grande probabilidade de provocar a reação do Estado 
iraniano, que se utilizaria de meios formais para tal. Além disso, facções armadas do Hezbollah certamente seriam empenhadas em combates não-convencionais em favor do regime de Bashar Al-Assad. Independentemente de tais projeções, é fato que o manifesto apoio dos governos da China e da Rússia quanto à não intervenção na guerra civil síria colaboraram para com o afastamento de qualquer colaboração por parte de outros regimes estatais com relação à derrocada do regime de Assad. No que se refere a esses dois importantes atores no cenário internacional, enfatiza-se que a Rússia possui na Síria sua única base militar na região do Mediterrâneo, em Tartus, o que também explica a nãoaceitação por parte do governo russo de qualquer envolvimento armado advindo de qualquer outro agente externo naquele território (SILVA, 2016, p. 163). Mesmo tendo-se registrado diversas violações de direitos humanos desde o início dos conflitos, não houve esforços políticos efetivos por parte da comunidade internacional até 2017, quando finalmente uma coalizão internacional veio a se formar com o intuito de combater o avanço do Estado Islâmico.

Analisando-se a questão do envolvimento externo no conflito sírio, enxergase, de forma ampla, que houve dois grupos principais lutando entre si, sendo um a favor da manutenção do regime de Al-Assad e outro opondo-se a tal regime. Para que os grupos que formavam a oposição pudessem atuar em meio à guerra civil que eclodiu na Síria, contudo, estes tiveram que obter financiamento suficiente e contínuo que pudesse lhes garantir apoio logístico e subsistência de seus integrantes. Esta conjuntura os coloca em uma posição desprivilegiada em relação ao regime. Em contrapartida, os representantes do regime de Bashar Al-Assad, que já possuíam tais tipos de recursos, lograram ainda em obter auxílio estrangeiro. Assim, desde o início de 2013, os grupos que lutavam pela manutenção do regime em vigor já não eram compostos, na realidade, pelo exército sírio propriamente dito, mas sim por homens oriundos dos aliados políticos estrangeiros de Assad, nomeadamente aqueles patrocinados pelo Irã. A história contemporânea da Síria, portanto, parece estar em um momento de ruptura, uma vez que as instituições estatais não mais conseguem exercer suas atividades de modo eficiente. Nesse panorama observase que a governança por parte do Estado sírio se resume à utilização da força frente a seus opositores internos, o que o coloca na pior condição a que pode chegar o aparato estatal (REY, 2018, p. 313-4). Essa situação caótica, similar àquela percebida no Iraque desde alguns anos antes, coloca a população síria em estado de ampla fragilidade, vindo a Síria a se constituir como um Estado falido, dadas as condições de flagrante ingovernabilidade por parte do regime. Restando a utilização da força como a última alternativa para que as 
instituições do regime em voga possam existir, ganham tração os grupos insurgentes que detêm meios de fazer frente ao Estado na luta armada. Uma vez que tais grupos insurgentes, incluindo-se a Frente Al-Nusra, se colocam como representantes de certas comunidades da fragmentada sociedade síria, a insurgência acaba por elevar seu status de representante de suas comunidades, as quais vêm em tais grupos a única alternativa de garantir seus interesses em médio e longo prazo.

O período de guerra civil no país sem interferência externa durou o suficiente para permitir aos grupos insurgentes se organizarem, se fortalecerem e finalmente se unirem. Estas condições estariam diretamente ligadas à formação do Estado Islâmico, mais precisamente naquilo que se refere à associação da Frente Al-Nusra ao Estado Islâmico do Iraque. O período de não-intervenção internacional, por assim se dizer, acabou por ser um dos fatores preponderantes ao surgimento do Estado Islâmico, cujos opositores, na esfera militar, não foram capazes de lhe fazer frente durante vários anos. A liderança do Estado Islâmico soube utilizar com maestria a configuração das forças durante a guerra civil síria, aproveitando-se de relativa liberdade para operar em diferentes frentes militares, durante as quais ocupou extensos e importantes territórios. Isto significa, numa primeira avaliação, a tomada e o consequente controle de fontes de renda diversas como campos petrolíferos e rotas de comércio diversos. Somado a isso está o efeito social e político das inúmeras vitórias militares do Estado Islâmico frente às forças regulares sírias e de outros grupos armados que lhes fizeram frente - incluindo-se representantes do Hezbollah e outros grupos financiados pelo Irã e pelos Estados Unidos - , o que incrementou ainda mais o número de adeptos dos territórios conquistados e serviu de chamariz para indivíduos de países além do Oriente Médio (Cf. MCCANTS, 2015).

Percebe-se, entretanto, que mesmo em um local em que os sunitas são minoria e sem contar com o apoio, inicialmente, de outros grupos com o mesmo tipo de objetivo, a organização autodeclarou-se um califado e, em ato contínuo, passou à luta armada para expandir seus territórios, subjugar cidades importantes e conquistar posições estratégicas no Iraque e na Síria (Cf. HOLBROOK, 2015). Iniciou-se então um conflito supranacional, tendo de um lado o denominado Estado Islâmico, uma organização com que, por meio de ações violentas embasadas em interpretações do islamismo bastante peculiares, tem imposto sua doutrina e governança a vastas regiões, principalmente no Iraque; e, do outro lado, diversos grupos armados e exércitos nacionais procurando impedir a expansão objetivada pelo Estado Islâmico. 
Portanto, a Primavera Árabe e a consequente Guerra Civil Síria contribuíram para com que surgissem grupos que mais tarde viriam a formar o Estado Islâmico do Iraque e da Síria. Dentre tais grupos destaca-se o grupo sírio Al-Nusra, que tinha por objetivo suplantar o governo do presidente Bashar al-Assad por um emirado islâmico, de acordo com o estipulado pela liderança do Estado Islâmico do Iraque (Cf. GERGES, 2016, p. 16). À luta armada da Al-Nusra juntou-se o Estado Islâmico do Iraque, e desta união formou-se então a organização autointitulada de Estado Islâmico do Iraque e da Síria (REILLY, 2016, p. 157). A partir daí o movimento desse grupo ganha força tanto na Síria quanto no Iraque, pois se expande rapidamente em direção à província iraquiana de Anbar, cuja capital, Ramadi, torna-se uma de suas bases. Repara-se, então, que os protestos da primavera árabe colocaram em choque os interesses governamentais e de grupos minoritários, formando-se, no caso da Síria, um contexto que levaria ao envolvimento de diversos grupos armados em busca de poder. Estudar esses acontecimentos é de suma importância para a compreensão da origem do Estado Islâmico e sua contribuição para com a instabilidade sociopolítica da Síria e de suas zonas fronteiriças. 


\section{O ESTADO ISLÂMICO DO IRAQUE E DA SÍRIA}

Durante o desenrolar dos acontecimentos em meio à Primavera Árabe na Síria os grupos jihadistas vieram a se tornar proeminentes de tal forma que a Al-Qaeda deixou de ser tida como a principal força em território sírio. Em meio a esse conflito, o novo líder do Estado Islâmico do Iraque, Abu Bakr Al-Baghdadi, oficializou a união de seu grupo com os jihadistas da Frente Al-Nusra, denominando-se o novo grupo então, em abril de 2013, como Estado Islâmico do Iraque e da Síria (REILLY, 2016, p. 157). A fusão entre os dois grupos, entretanto, não se deu de maneira simples. Após a declaração unilateral de Al-Baghdadi em 9 de abril de 2013 de que a partir de então a Al-Nusra seria subordinada à sua organização, formando o Estado Islâmico do Iraque e da Síria, não foi aceito nem tolerado pela liderança da Al-Qaeda Central e da própria Al-Nusra. Como esclarece Plebani (2014, p. 12-3), na realidade tal declaração pode ser vista como bastante improvável. Levando em consideração a natureza nacionalista de fato de ambos os grupos àquela altura - o Estado Islâmico do Iraque colocava em prática a "iraquização" do grupo, ao passo que Al-Julani utilizava-se do lema "sírios primeiro". Esse seria um dos motivos pelos quais muitos líderes e grupos associados à Al-Nusra recusaram-se em se subjugar ao Estado Islâmico. Tendo a Al-Qaeda Central, na pessoa de Al-Zawahiri, procurado contornar a situação diplomaticamente - uma vez que sua organização seria a maior prejudicada, já que assim perderia dois grupos afiliados no Oriente Médio - o que se seguiu foi um confronto direto entre a Al-Nusra e o próprio Estado Islâmico do Iraque e da Síria. Naquilo que Gerges vê chama de "guerra civil jihadista" (2016, p. 16), o Estado Islâmico teve de enfrentar duros combates ante à Frente Al-Nusra e lhe conquistar as principais cidades que mantinha sob seu controle. Somente após ter angariado a lealdade dos membros estrangeiros da Al-Nusra - isto é, os não-sírios - e se imposto militarmente, o Estado Islâmico do Iraque e da Síria acabou por se formar efetivamente, em fevereiro de 2014. Concomitantemente, a Al-Qaeda Central acabou por romper relações com a organização de Al-Baghdadi (PLEBANI, 2014, p. 13; GERGES, 2016, p. 16).

Levando em consideração os diferentes aspectos envolvidos em uma avaliação a respeito do Estado Islâmico do Iraque e da Síria, estes serão analisados sob diferentes pontos que têm relação com sua origem, de maneira que possam estudar as circunstâncias em que tal surgimento ocorreu e que elementos envolveu. 


\subsection{QUESTÕES IDEOLÓGICO-RELIGIOSAS E SOCIAIS LIGADAS O SURGIMENTO DO ESTADO ISLÂMICO}

A importância de se compreenderem questões diversas relacionadas à religião islâmica e às ideologias observadas pelo Estado Islâmico reside no fato de que estas incidem diretamente na forma de organização, na sua liderança e na sua atuação. Como tal organização se coloca como um grupo islâmico sunita de ideologia salafista-jihadista, há que se trazer à tona definições sobre vertentes religiosas e ideológicas como o wahhabismo e o salafismo, uma vez que tais ideologias têm influenciado questões sociais, políticas e culturais ao longo dos séculos XX e XXI. O Estado Islâmico pode ser considerado salafista, uma vez que compartilha da visão da Al-Qaeda quanto à necessidade de se purificar o Islã ao se promover o retorno a um modo de vida análoga à das primeiras gerações de muçulmanos. A observância dos preceitos dessa ideologia é condição sine qua non a todos os integrantes da organização e forçada àqueles que vivem nos territórios sob seu jugo.

Diversos líderes religiosos islâmicos em todo o mundo têm apresentado profundas discordâncias quanto à interpretação dos ensinamentos islâmicos difundidos pelo Estado Islâmico do Iraque e da Síria. Com o fito de expor críticas a respeito, foi criada uma página na internet com a finalidade de divulgar, em diferentes línguas, uma carta aberta a Abu Bakr Al-Baghdadi - segundo líder do Estado Islâmico, sucessor do seu fundador -, indicando os pontos de discordância entre a fé islâmica e os ideais promovidos por sua organização. Por esse motivo, quando da ocorrência de atentados terroristas ou da divulgação de execuções promovidas pelo grupo, formadores de opinião e líderes religiosos muçulmanos têm se preocupado em divulgar esclarecimentos a respeito de que as comunidades que integram e representam não compactuam de forma alguma com tal tipo de conduta. Com isso, a grande maioria da população muçulmana visa desvincular seus preceitos ideológico-religiosos do comportamento difundido pelo Estado Islâmico, afastando-se das diferentes formas de manifestação de fundamentalismo islâmico. Entendem, desta maneira, que a visão de mundo da organização ora discutida não se adequa à interpretação majoritária dos ensinamentos da fé islâmica.

Assim, amparada em determinadas interpretações religiosas, a organização em questão tem promovido assassinatos em massa e promovido a destruição de símbolos religiosos seculares, inclusive islâmicos, de valor inestimável. Como aponta Dyer (2013, 
p. 54), ao se observarem os títulos usados pelo líder do Estado Islâmico, como califa e emir ${ }^{23}$, bem como o nome hoje utilizado pelo mesmo, Abu Bakr Al-Baghdadi (que remonta ao primeiro califa do Islã, Abu Bakr), pode-se perceber o peso do componente religioso para a organização, ao menos no campo retórico.

Algum tempo após a criação do Estado Islâmico do Iraque e da Síria, pessoas e instituições mundo afora passaram a manifestar seu apoio à nova organização. Mesmo registrando-se grande oposição em razão de terem abandonado a Al-Qaeda, muitos dos integrantes desta última se viram atraídos pelo Estado Islâmico, assim como jihadistas que já haviam lutado no Afeganistão e outros locais. Ideólogos, pensadores e teólogos também manifestaram sua aprovação diante dos discursos iniciais e das ações promovidas pelo Estado Islâmico.

Um documento escrito pelo próprio Al-Zarqawi expõe bem tal interpretação. Em janeiro de 2004 agentes de inteligência da região autônoma do Curdistão iraquiano interceptaram uma carta que teria sido enviada por Al-Zarqawi a Osama bin Laden, na qual comunica seu receio quanto à expansão de um eventual estado xiita, que poderia envolver países como Irã, Iraque, Síria e Líbano. Suas preocupações se referem ao Programa de de-baathificação da Autoridade Provisória da Coalizão norte-americana, uma vez que esta havia tornado as forças armadas, polícia e inteligência iraquianas em instituições xiitas. Intitulando seus pensamentos de "plano de trabalho", Al-Zarqawi expõe sua visão, a qual tem no xiismo uma ameaça maior do que seus inimigos militares, como as forças armadas americanas e seus aliados. Desse modo, planejando causar motivação para dar início a uma guerra sectária contra os xiitas, o documento cita "alvejar seus símbolos religiosos, políticos e militares, fazendo-os mostrar sua raiva contra os sunitas, o que então provocaria a vingança" (Cf. GRIFFIN, 2016, p. 8).

Entretanto, com o desenvolvimento das ações extremamente violentas do grupo liderado por Al-Zarqawi, após algum tempo muitos formadores de opinião do mundo muçulmano passaram a dirigir incisivas críticas à maneira como o Estado Islâmico conduzia sua luta jihadista. A propagação da ideologia salafista-jihadista, por mais que conquistasse adeptos dentre inúmeros muçulmanos, também tinha nas suas ações terroristas um catalizador de críticas e desaprovação crescentes. Dentre estes destaca-se

\footnotetext{
${ }^{23}$ Do árabe "líder" ou "príncipe." Trata-se de título de cunho político cuja origem vem do termo amara (“comandar”, em árabe), concedido a figuras de alto escalão político (Cf. MATTAR, 2004, p. 2621).
} 
o grande criticismo por parte de Abu Muhammad Al-Maqdisi, que além de influente ideólogo jihadista exerceu grande inspiração à mentalidade do primeiro líder do Estado Islâmico. Na visão de Al-Maqdisi, a brutalidade e a violência contra quaisquer alvos indistintamente, e sobretudo o fato de não se reconhecer a autoridade do líder da AlQaeda como um mediador para solucionar problemas junto a outras comunidades islâmicas, tratavam-se de questões extremamente condenáveis. As críticas por parte de Al-Maqdisi continuaram a ponto de ter este emitido uma nota, em maio de 2014, com a finalidade de que esta fosse amplamente divulgada, classificando o Estado Islâmico como uma "organização desviante", a qual teria deixado de trilhar o caminho da verdade, passando a adotar a agressão e a violência como meios para seus objetivos. Esse influente ideólogo jihadista expressamente acusou ao Estado Islâmico, ainda, de promover a ignorância através de mentiras, incorrendo em tirania e em falsificações. Chega a mencionar que em contato com representantes do Estado Islâmico estes lhe confidenciaram que dentre as fileiras da organização havia diversos membros que poderiam ser melhor descritos como kharidjitas (Cf. HOLBROOK, 2015, p. 97).

A utilização de tal termo deve ser enfatizada pois, nesse contexto, seu significado vai além daquele já exposto nesta pesquisa. No sentido utilizado por AlMaqdisi, o termo kharidjita se refere àquele que se atém de forma extremista à pureza doutrinária e à noção de excomunhão no Islã. Quanto à questão da excomunhão (em árabe, takfir), tal conceito se relaciona à violência praticada em decorrência da não observância dos preceitos religiosos islâmicos por determinado indivíduo, o que justificaria sua morte - o que caracteriza a violência takfiri - elemento também presente na ideologia salafista-jihadista. Denota-se, deste modo, que rotular os integrantes do Estado Islâmico como kharidjitas visa sobretudo deslegitimar suas ações, colocando-os como excessivamente violentos no intuito de desestabilizar a ordem política do meio em que se encontram (Cf. HOLBROOK, 2015, p. 98).

Aquilo que se denomina takfir, aliás, deve ser entendido como uma ideologia extremista inserida no pensamento salafista-jihadista, a qual leva o conceito de utilização da violência a níveis altíssimos, bem como ao entendimento de heresia dentro dos ensinamentos islâmicos. Propagada desde o final da década de 1960 por Shukri Mustafa, líder da organização egípcia Takfir wa al-Hijrah (em árabe, "Excomunhão e Hégira"), na ideologia takfir se enxerga que todos aqueles que não sigam os preceitos islâmicos fielmente - mesmo aqueles indivíduos que se dizem muçulmanos, mas que sigam preceitos considerados incorretos - são tidos como hereges (Cf. DEMANT, 2006, p. 103; 
MELAMED, 2016, p. 44). Aqueles vistos deste modo são considerados então como os piores inimigos do Islã. Isto embasa, dentro dessa visão, combater a todos que se insiram nessas condições, pois os infiéis corromperiam o Islã e seus valores. Esses pensamentos fazem com que a maioria das vítimas da violência motivada por ideias de tal sorte seja, em sua maioria, de muçulmanos (Cf. MELAMED, 2016, p. 73-5).

O Corão traz passagens acerca tanto de paz quanto de guerra, as quais devem ser interpretadas com base nos extensos registros orais atinentes à conduta do profeta Maomé e na tradição religiosa islâmica. Tais registros, ao compor a base da interpretação religiosa islâmica, abrem, indubitavelmente, oportunidades para diferentes entendimentos. Consequentemente, passa a existir uma enorme miríade de orientações de conduta para as comunidades muçulmanas, dentre as quais acaba por haver algumas interpretações que levam à violência. A interpretação da jihad é tema bastante controverso dentro do islamismo, o que opõe diferentes líderes religiosos e escolas de pensamento. Daí resulta a lide existente entre diferentes organizações e até entre comunidades muçulmanas. No caso daquelas que vêm na jihad um motivo para a prática da violência contra aqueles que não compartilham de sua mesma visão do Islã, o termo jihadista se lhes aplica justamente em função da peculiaridade de sua interpretação. Como coloca Lewis (2004, p. 24), no caso das organizações salafistas que promovem a jihad à força, cunha-se o termo salafismo-jihadismo, ao que se enquadra o Estado Islâmico do Iraque e da Síria. Esta concepção é tida pelos muçulmanos que não compartilham de tal visão como uma interpretação grotesca da religião islâmica e da própria doutrina da jihad.

Analisando-se a influência da ideologia jihadista-salafista na ampliação do apoio ao Estado Islâmico em suas mais variadas formas, percebe-se que a crescente utilização da violência por parte da organização não seria um fator que lhe permitiria uma continuidade em sua ampliação. Quando do surgimento da organização, a situação caótica e de violência generalizada tanto no Iraque quanto na Síria serviam, de alguma forma, para legitimar o uso de táticas terroristas pelo grupo. Havendo um inimigo violento a ser combatido, o grupo acatou a prática da violência para conseguir seus objetivos. Sejam os representantes dos Estados Unidos no Iraque, seja o governo de Bashar Al-Assad na Síria, ambos se valeram da força, inicialmente, para exercer o poder sobre as comunidades sunitas de onde se agrupariam os futuros integrantes do Estado Islâmico do Iraque e da Frente Al-Nusra, no caso da Síria. 
As sociedades nas quais o Estado Islâmico do Iraque e da Síria se formou se encontravam em meio ao caos social, econômico e político. Os serviços básicos deixaram de funcionar, os alimentos tornaram-se escassos, as fontes da água e de eletricidade não eram suficientes, e grande parcela da população não tinha trabalho remunerado. Assim, saques e crimes violentos aumentaram exponencialmente. Tanto o Iraque quanto a Síria foram envolvidos em violentos conflitos sectários, que acabou por evoluir a um movimento de insurgência contra os poderes dominantes (Cf. KUBBA, 2010). Essa realidade vem a demonstrar que quando o caos se instala há uma oportunidade para diferentes grupos disputarem o poder, o que geralmente gera conflitos extremamente violentos. Muito comumente os indivíduos que integram grupos desse gênero têm forte motivação pessoal para lá estarem. A maioria tem sua origem em grupos da elite políticosocial, militares, trabalhadores altamente qualificados e funcionários de diferentes escalões governamentais. Porém, após as profundas mudanças sociais causadas pela guerra, esses indivíduos tornaram-se inúteis, desempregados e caíram em desgraça social. Em tal conjunturas, muitos daqueles que lutam para ascender socialmente para sobreviverem e manterem suas famílias, vêm nos grupos salafistas-jihadistas uma oportunidade para garantirem seu sustento. Têm aí ainda maiores chances para galgar rapidamente a altas posições sociais, tendo acesso a postos de poder e a meios que lhes podem permitir alcançar seus objetivos pessoais. Daí se infere haver, para tais indivíduos, a necessidade de encontrar um novo significado e um novo sentido para suas vidas, seja para garantir o bem-estar de seus dependentes quanto de se manter seu status social.

No entanto, como afirma Egerton (2011, p. 27), também é crucial compreender que os fatores pessoais são tão importantes quanto os sociais. Um número significativo de militantes que participam de grupos terroristas salafistas-jihadistas sofreu algum tipo de tragédia em suas vidas, ou experimentou algum tipo de infelicidade que levou a profunda angústia. Neste ponto se insere a questão das precárias condições de vida em que se encontrava a grande maioria tanto da população síria quanto da iraquiana à época em que eclodiram os movimentos insurgentes sunitas que dariam início ao processo de formação do Estado Islâmico do Iraque e da Síria.

Não foi só a luta armada que se constituiu num ponto motivador à prática da violência junto a tais comunidades. A coação psicológica e a opressão ideológicoreligiosa exercida sobre uma parcela da população sunita pode ter sido, como se vê, causadora de uma postura mais beligerante por parte deste grupo, o qual passou a aceitar melhor, ou a tolerar, a influência salafista-jihadista em suas comunidades. 
Consequentemente, a disseminação de ideias ligadas a essa ideologia se tornou óbvia, e, conforme se verificou inicialmente no Iraque e mais tarde na Síria, as organizações dessa natureza não tiveram grandes dificuldades em cooptar milhares de seguidores em curto espaço de tempo. Mesmo havendo razões para que sunitas se juntassem aos grupos em questão, como econômicas e de segurança, o fator ideológico também se apresenta como de grande relevância para o sucesso do Estado Islâmico em seus programas de recrutamento. $\mathrm{O}$ fato de tal organização estabelecer um objetivo de grande significado social, ideológico e religioso vai, ao menos no campo retórico, muito além dos objetivos normalmente propostos por outras organizações fundamentalistas e governos de Estados formalmente constituídos. O grupo manifesta a disposição da liderança do Estado Islâmico em lutar de maneira ferrenha por seus ideais, fazendo de tudo que estiver ao seu alcance para alcançar as condições propostas à sua comunidade. Isto se percebe como um enorme atrativo psicológico e material para o aliciamento de um número crescente pessoas das mais variadas origens à sua causa, valendo-se do sucesso propagandísticos para tanto. Tal propaganda, envolvendo violência e outras demonstrações de força contando normalmente com a colaboração inequívoca de veículos de mídia de massa mundo afora - torna a organização cada vez mais conhecida, o que de fato amplia o número de adesões à causa pela qual o grupo luta. Indiretamente, o Estado Islâmico acaba por criar cada vez mais simpatizantes para suas próprias fileiras. Esse incremento de seguidores e colaboradores permite à organização obter um aumento de sua força progressivamente, "até que esteja em condições de enfrentar os agentes da opressão a que se julgam submetidos" (Cf. DINIZ, 2010, p. 166-8).

Percebe-se que a propaganda utilizada pelo grupo se apresentou muito mais eficaz do que se imaginaria possível para um grupo de tal porte, ainda mais nas condições em que se encontrava em sua fase inicial. O Estado Islâmico lançou mão da divulgação de arquivos de vídeo em diversas páginas da internet com o intuito de aliciar pessoas em todo o mundo a se juntarem à organização. Como a internet possui nos dias de hoje uma grande influência dentre os meios de comunicação e se tornou um valioso meio de recrutamento para grupos diversos, tal plataforma acabou por se tornar uma espécie de comunidade. Viabilizou-se assim a troca informações acerca dos assuntos de interesse comum, reforçando e massificando determinados preceitos ideológicos, inclusive para se discutirem formas de se promover causas e ideias peculiares à sua ideologia. Cita Nydell (2012, p. 106) que muitas páginas na internet se assemelham a cultos, e seus membros 
muitas vezes as utilizam como munição ideológico-teológica para dar sequência ao confronto de ideias que se dá nos websites mantidos exatamente com essa finalidade.

Pode-se enxergar até que o Estado Islâmico trouxe uma evolução no que diz respeito à utilização da internet quando comparada com a Al-Qaeda, demonstrando grande capacidade de divulgação de suas causas e objetivos a um nível que esta última jamais alcançou (Cf. STERN e BERGER, 2015, p. 22-3). Os alvos de tal tipo de aliciamento não se tratam, como talvez se poderia imaginar, somente de árabes que querem lutar contra os invasores de suas terras, mas sim toda e qualquer pessoa que manifestasse o desejo de se juntar e colaborar com o Estado Islâmico, independentemente do gênero, idade, nacionalidade ou profissão. Este tipo de recrutamento indica uma mudança no perfil das pessoas que a liderança do grupo procura, o que denota um afastamento do elemento nacionalista observado inicialmente.

A busca por novos integrantes não se dá, obviamente, somente através de tais vídeos. Células espalhadas por diversos países em todo o mundo têm convertido ao islamismo e aliciado milhares de homens e mulheres a viajar à Turquia - de forma a procurar burlar os esforços policiais no sentido de impedir tal tipo de recrutamento - para então, por terra, acessarem a Síria e integrar o Estado Islâmico (Cf. STERN e BERGER, 2015, p. 86). Essa situação suscitou preocupação e esforços por parte de muitos governos na tentativa de impedir a continuidade do trabalho de recrutamento promovido pelo Estado Islâmico.

Dentre os meios de propagação da ideologia com a qual o grupo se identifica estão websites e revistas digitais, editadas em diversas línguas. Dentre estas se destaca a revista digital Dabiq, publicada em inglês e outros idiomas - dada a importância do alcance internacional de sua ideologia - a qual acena para o recrutamento de simpatizantes e, por óbvio, promove os valores da organização (Cf. REILLY, 2016, p. 158; SILVA, 2017, p. 160). Este periódico, cuja denominação se refere à cidade síria de Dabiq - mencionada em uma hadith do profeta Maomé que se refere à vida além da morte (Cf. RYAN, 2014) - tratava basicamente de ideias ligadas ao progresso do projeto de formação de um califado, bem como divulgava de atos de heroísmo e ensinamentos islâmicos. Relevante também eram os artigos nos quais se discorria acerca da justificação de suas ações. Quando o Estado Islâmico teve de deixar a cidade de Dabiq em meio aos confrontos armados, a revista deixou de ser publicada. Tal fato impactou negativamente na divulgação do conteúdo de que aquele canal se utilizava. Suas edições compreendem 
ao período, portanto, de julho de 2014 a julho de 2016, após o que deu lugar à revista Rummiah - Roma, em português -, cujo nome remonta à almejada tomada dessa cidade pelos muçulmanos, em referência ao objetivo final do Estado Islâmico de suplantar o marco do cristianismo, em clara alusão à derrocada do ocidente (Cf. GERGES, 2016, p. 140). Entretanto, os principais temas abordados na publicação pouco mudaram, marcando-se, entretanto, maior ênfase em temas ligados à resistência de seus adeptos frente às derrotas e dificuldades, e na manutenção da lealdade para com a causa da organização (Cf. WELCH, 2018, p. 9-10).

Apesar de o período de publicação das revistas supramencionadas ter se dado em momento em que o Estado Islâmico já havia se consolidado, conhecer seus temas e conteúdo é crucial para se discutir a importância que é dada à propaganda ideológica pelo grupo em questão, o que, obviamente, já era realizado muito antes da Dabiq. Uma vez que a Al-Qaeda se utilizava da revista Inspire para divulgação ideológica (Cf. GERGES, 2016, p. 206), e sendo que o Estado Islâmico se originou de ramificação dessa organização, nota-se que a utilização desse tipo de mecanismo não foi uma inovação do Estado Islâmico, mas sim uma evolução. As novas tecnologias, claro, trouxeram novas possibilidades à organização, o que lhes permitiu desenvolver formas mais rápidas e eficientes de propaganda - a ponto de se vincularem à produtora de mídia síria Al-Hayat. Contudo, de maneira alguma isso significaria que na década anterior Al-Zarqawi, ou mesmo Al-Baghdadi, se preocupassem menos com a melhoria da eficiência de seus métodos de propaganda ideológica.

O emprego de diversos mecanismos de disseminação ideológica são uma demonstração da importância que a própria organização deu a esse ponto. Contudo, para fins de análise na presente investigação, podem-se usar como forma de mensuração do grau de sucesso que atingiu a ideologia do Estado Islâmico a preocupação do líder da AlQaeda em se valer da retórica não só para desacreditar a forma como a ideologia propagada pelo Estado Islâmico vinha sendo difundida, mas também para colocar que tal modo de pensamento acarretaria derrotas ao grupo, pois impactaria negativamente no seu campo estratégico. Com esse desígnio, Al-Zawahiri, perante o crescimento e a solidificação da nova organização, se valeu de contundentes críticas à excessiva violência causada pelos integrantes do Estado Islâmico, colocando, principalmente, que o uso de tal grau de violência contra outros muçulmanos viria a causar ataques em massa que, até para os adeptos do islamismo militante, poderiam ser rotulados como extralegais (Cf. HOLBROOK, 2015, p. 95). Os frutos colhidos pela organização foram além do esperado 
inicialmente, ao menos na visão de observadores internacionais. A plena utilização de mecanismos e ferramentas de tecnologia de informação e comunicação, principalmente através da rede mundial de computadores - a qual, aliás, já fora fundamental na mobilização popular durante os levantes da Primavera Árabe na Síria - seriam fundamentais para a dispersão do viés ideológico (Cf. BAZZAN, 2014, p. 39) e dos objetivos apresentados pelo Estado Islâmico, assim como para a mobilização de integrantes do grupo, inclusive além das fronteiras do Oriente Médio.

A condição atual desse tipo de organização, sobretudo naquilo que se refere à organização e atuação decorrentes da disseminação de sua ideologia e metodologia encontram-se atualmente bastante desenvolvidas. A experiência adquirida pelos seus líderes e os exemplos obtidos de grupos análogos lhes permitem estabelecer uma estrutura similar à de grandes empresas. Como observa António Lara,

as células terroristas atuais são agora bastante autocéfalas. Estão apenas unidas numa primeira fase (na formação doutrinária e tática) para depois se isolarem no contexto de uma inclusão social participante, dentro da vida habitual de uma determinada comunidade. A partir daí geram a sua própria autonomia de complemento de formação tática, logística e de desempenho geral, visto que a definição de sua estratégia é pública, uma vez que se encontra permanentemente disponível na Internet ou na televisão $(2015$, p. 45$)$.

As críticas à ideologia acima discutidas demonstram mais do que visões diferentes por parte de outros grupos salafistas-jihadistas. Tal criticismo deixa claro que, a partir da constituição da organização Estado Islâmico como tal, prontamente seus líderes tiveram de se empenhar em uma disputa ideológica com a Al-Qaeda, com quem até pouco tempo antes compartilhavam dos mesmos objetivos. Isto se constitui em um sério obstáculo à concretização dos planos de disseminação ideológica por parte do novo grupo. Levanta, numa análise primária, outra questão importante. O Estado Islâmico estava diante de uma disputa ideológica contra um grupo que não só contava com maior reconhecimento internacionalmente, mas era justamente o grupo que integrara até pouco tempo antes. Ou seja, a nova organização teria que superar a Al-Qaeda quanto ao apoio obtido no campo das ideias junto às populações muçulmanas mundo afora. Para isso, nota-se que havia para o Estado Islâmico a necessidade de se destacar da Al-Qaeda, de se desvincular desta, seja na esfera ideológica quanto na de execução. Tal demanda pode explicar os motivos de ter o Estado Islâmico promovido ideias tão mais radicais do que as da Al-Qaeda. Um exemplo é a declaração de que todos os muçulmanos que não 
compartilhassem da visão ideológica do Estado Islâmico seriam considerados apóstatas. Mais que isso, sua atuação também atingiu graus de violência nunca vistos antes (Cf. HOLBROOK, 2015, p. 98).

A questão ideológica, percebe-se, é deveras importante para o crescimento de grupos salafista-jihadistas. O Estado Islâmico não é exceção, dada a ampla utilização de meios de comunicação para a disseminação da ideologia construída com base em interpretações próprias do salafismo e do jihadismo. A respeito desse assunto, são de grande contribuição para esta pesquisa as colocações de Donald Holbrook (2015, p. 1012), o qual elenca três pontos importantes para que o Estado Islâmico se tornasse consistente no campo ideológico.

O primeiro ponto trata da necessidade de os jihadistas contarem com amplo apoio. Daí se extrai que a legitimidade de suas campanhas teria pouco sucesso em médio e longo prazo, no caso de carecerem de apoio ideológico por parte das sociedades iraquiana e síria, sem falar da própria comunidade sunita em diversos outros países.

O segundo elemento cita a existência da noção de unidade entre os jihadistas como uma maneira de atrair seguidores e simpatizantes. De certa forma, este ponto complementa o primeiro, já que o sentido de união dentre tal comunidade só seria possível após terem angariado amplo apoio, pois somente então surgiria a preocupação de se perfazer uma união estável e duradoura, a qual garantiria a continuidade consistente do projeto salafista-jihadista.

Por fim, o autor menciona como terceiro ponto a importância de exprimir uma mensagem consistente aos seguidores em potencial. Ou seja, em se considerando já consolidados os outros dois pontos - amplo apoio e união -, torna-se necessário haver uma unicidade ideológica que, obrigatoriamente, se traduza em uma mensagem única tanto aos seus adeptos quanto, como se denota, aos indivíduos identificados como potenciais seguidores. Daí se permite compreender que, em havendo ideias desconexas ou mensagens não concatenadas entre si, seria impossível se manter apoio suficientemente amplo e, da mesma forma, a união entre seus integrantes.

É válido conhecer, de forma a complementar tais interpretações, o entendimento de Quintan Wiktorowicz a respeito. Este, detendo suas observações exclusivamente ao caso do Estado Islâmico, afirma que este grupo 
teve condições de prosperar não só por causa de sua força material e de táticas cruéis, mas também porque ele respondeu às preocupações dos sunitas no Iraque, na Síria e em outros lugares, os quais viam seu modo de vida ameaçados. Qualquer uso da força contra alvos do Estado Islâmico, a partir daí, deve ser acompanhado de um conjunto de medidas destinadas a proteger os interesses dos sunitas marginalizados (2014, p. 15).

Extrai-se daí importância da ideologia para o Estado Islâmico face à sua estratégia que visava a implementação de um califado no Levante, a qual foi utilizada como eficaz ferramenta para se angariarem adeptos suficientes. Isso viabilizou garantiu que suas ações seguissem um padrão homogêneo como consequência de uma forma de pensamento único. Os líderes do Estado Islâmico souberam, como ficou evidente, fazer uma leitura correta das necessidades dos cidadãos iraquianos e sírios que se apresentavam como potenciais adeptos. Vale lembrar que, ainda que o primeiro líder do grupo não tivesse tido alto grau de escolaridade, seu sucessor, Al-Baghdadi, não só possuía formação universitária e profundos conhecimentos religiosos islâmicos, mas também se tratava de um professor de direito islâmico possuidor de diploma de doutorado. Por isso, tem-se que Al-Baghdadi possuía grande conhecimento acerca do islamismo e, por óbvio, das diferentes doutrinas ideológicas que o compõem. Seu conhecimento lhe possibilitou, como ficou patente, enxergar as necessidades imateriais por parte dos sunitas iraquianos e sírios durante os conflitos sectários que se desenvolviam, sendo-lhe possível assim divisar as oportunidades que se lhe assomavam. O Estado Islâmico passou a investir então na disseminação da ideologia salafista-jihadista em meio às comunidades retrocitadas, de modo a suprir o vácuo ideológico de grande parcela da população do Iraque e da Síria.

Embora a destruição material generalizada e o roubo da propriedade cultural não sejam um fenômeno durante conflitos, as ações por parte do Estado Islâmico revelam novas condutas extremistas no que se refere à propriedade cultural. A destruição, nesse campo, não é um efeito colateral do conflito armado, mas sim algo bem planejado, que se vale da utilização técnica de meios sofisticados de produção de imagens. Esses atos são pensados para que sejam transmitidos tanto localmente quanto internacionalmente, imprimindo-se assim a visão ideológica do Estado Islâmico, mormente quanto à intolerância de qualquer símbolo que faça alusão a valores nocivos aos seus objetivos.

Outro elemento que se extrai dessa conjuntura é que o grupo se vale de tal artifício justamente para exercer o domínio cultural sobre a população dos territórios em que se instalou. Assim, torna-se possível à organização reduzir culturalmente certas 
comunidades, apagando os símbolos de sua história e a sua memória cultural. Dentro dessa acepção, convém observar a avaliação de Helga Tarku (2018, p. 2-4), a qual menciona que atacar a propriedade cultural do outro - e através disso sua história e memória - tem profundas consequências para a sobrevivência do grupo, pois a memória consiste na essência de qualquer identidade. É este aspecto fundamentalmente importante de propriedade cultural que o tornou alvo primário do Estado Islâmico na condução de sua guerra. Finalmente, o roubo de propriedade cultural do berço da civilização mundial não é somente algo empobrecedor à herança cultural da Síria e do Iraque, mas também potencializa o terrorismo praticado pelo Estado Islâmico. Ou seja, enxerga-se que a destruição e o saque de bens culturais têm sido características significativas das ações do Estado Islâmico, o que, dentro de uma interpretação mais extensiva, pode também ser considerado terrorismo, pois são atingidos bens imateriais de valor inestimável para as sociedades a que pertencem.

O Estado Islâmico também manteve outro modo de difusão ideológica que já era utilizada pela Al-Qaeda no Iraque, a qual não necessitava nem dependia de equipamentos de comunicação que demandassem alta tecnologia. A propagação das ideias de forma pessoal levada a cabo por seus representantes ou simpatizantes não poderia ser abandonada, e deveria não só continuar de forma organizada, mas também se expandir. Com esse propósito, o Estado Islâmico não só manteve como também estabeleceu novos centros de difusão ideológica, nos quais atuava de modo discreto, sendo necessárias, em muitos casos, utilizar-se de uma instituição de fachada para garantir que autoridades estatais não interferissem. Operando à margem da fiscalização e da supervisão de entes governamentais e de autoridades policiais, essas organizações provaram ser um eficaz meio de propaganda, já que, mesmo em casos em que foram submetidas a investigações diante da acusação de financiamento do terrorismo em vários países, grande parte da rede de contribuidores se manteve atuante (Cf. GÓMEZ, 2010, p. 9).

Atos de terrorismo, ainda que tidos dentro de uma visão estratégico-política como um meio para a consecução de objetivos maiores, como já tratado aqui, acaba por se colocar como um importante elemento identitário de qualquer organização, à medida em que a utilização de tal meio se coloca como uma importante questão para a aceitação social do grupo e também para o recrutamento de novos integrantes. De uma perspectiva psicossocial, portanto, o terrorismo não pode ser considerado como uma síndrome, mas como um método de influência política e social (DE LA CORTE, 2007). Psicólogos 
sociais descrevem o ambiente como o lugar onde o comportamento de uma pessoa é influenciado, levando-se em conta também suas predisposições psicológicas individuais. Contudo, a esfera de influência social tem papel fundamental no comportamento e na formação das crenças de outras pessoas. Portanto, a perspectiva psicossocial enxerga que vários processos de interação social devem ocorrer para tanto, seja dentro do grupo no qual o indivíduo está inserido, seja na interação com outros grupos com que venha a ter contato. Como se deve notar, muitos desses processos de influência se desenvolvem de forma deliberada, podendo fazer parte de uma estratégia pré-definida por indivíduos ou instituições. Nessa esteira, é comum identificarem-se organizações terroristas se valendo de formas de publicidade análogas a campanhas publicitárias de empresas comerciais para divulgar seus ideais e suas causas (Cf. DE LA CORTE, 2007, p. 7-8).

Ocorre que, comumente, os valores dos grupos terroristas representam crenças e posturas a respeito de questões político-religiosas que são aceitas somente por uma minoria dentre a sociedade em que operam. Como estabelece Serge Moscovici (1996), esta realidade se pode denominar, dentro de estudos sobre psicologia, como minorias ativas, as quais procuram ganhar cada vez maior influência, tentando persuadir a maioria a aceitar seus valores. Por meio da utilização persistente dos métodos de influência, essa minoria pode conseguir mudar inteira ou parcialmente a visão da maioria (Cf. MOSCOVICI, MUGNY e PÉREZ, 1991). Essa dinâmica pode ser muito bem aplicada ao caso dos grupos salafistas-jihadistas que se utilizam do terrorismo, com o que corrobora De la Corte, asseverando este que

o terrorismo não é muito diferente deste processo porque a propagação do medo ou do terror através da violência tem uma dimensão comunicativa. Lembre-se da relação entre terrorismo e propaganda: afinal, a violência terrorista é um meio de direcionar a atenção das pessoas para certos problemas (reais, exagerados ou fictícios) e divulgar as demandas políticas ou religiosas do terrorista (DE LA CORTE, 2007, p. 7).

Também de grande importância para a formação das características dos indivíduos que aceitam o terrorismo - e que comumente se inserem em grupos que se utilizam dessa prática - são os processos de interação social. A esse respeito a psicologia social também vê as características individuais como um resultado de diversos processos de socialização e interação, o que também pode ser relacionado ao contexto em que pessoas aderem a grupos salafistas-jihadistas. Além da forte influência por parte do ambiente político-social apresentado por amigos e parentes, o desenvolvimento de um 
indivíduo em meio a um ambiente marcado por ideias radicais também pode levar à adesão a um grupo terrorista que compartilhe de valores similares. Ademais, a inserção junto a grupos dessa natureza pode ser vista como resultado de relações interpessoais com partidários de ideias políticas ou religiosas extremistas. A esse respeito, é relevante a colocação de Marc Sageman (2004) quanto ao peso das experiências pessoais durante a formação para que jovens muçulmanos se tornem jihadistas radicais. O pesquisador coloca que fator "amizade com uma pessoa que tem opiniões jihadistas radicais" como o principal motivo de adesão a organizações jihadistas como a Al-Qaeda, constando em segundo lugar o motivo os "laços familiares."

Questão fundamental para a presente pesquisa é a relação que se pode perceber entre ciclos de mobilização política, incluindo-se protestos populares contra regimes políticos e o surgimento de organizações terroristas (Cf. TARROW, 1989; GONZÁlEZ CALLEJA, 2003, p. 33-76). Por vezes, extremistas pertencentes a tais grupos elegem o terrorismo como principal método de influência social (Cf. DE LA CORTE, 2006). Como diversos estudos indicam, longos processos de radicalização de determinados movimentos políticos ou religiosos podem levar a campanhas terroristas por parte de determinados grupos (Cf. REINARES, 1998). Um aspecto que as organizações terroristas partilham com movimentos políticos ou religiosos comuns é o papel central desempenhado pelos processos psicológicos de identificação coletiva, sendo que normalmente as organizações terroristas apresentam-se como defensoras dos valores e interesses de uma comunidade étnica ou religiosa (Cf. JAVALOY, RODRÍGUEZ e ESPELT, 2003). Valendo-se da Teoria da Identidade Social, conforme proposto pelos psicólogos sociais Henri Tajifel (1981) e John Turner (1987), a auto identificação dos terroristas como membros de uma comunidade consideravelmente maior irá ajudá-los a cumprir seus objetivos.

Traçando-se um paralelo com os casos do Iraque e da Síria, os processos percebidos nesses dois países, ainda que se referissem primariamente a propósitos políticos, traziam importantes elementos ideológico-religiosos. Ou seja, ainda que os grupos que se utilizam do terrorismo o fizessem com o intuito de obter mudanças sociais através da derrubada dos regimes políticos, os grupos responsáveis pela mobilização social o faziam com base em elementos ideológico-religiosos percebidos como questão identitária. Em ambos os países, o sunismo tratava-se da principal questão religiosa que a Al-Qaeda no Iraque e a Frente Al-Nusra utilizariam para angariar apoio social. 
$\mathrm{Na}$ verdade, poucos dos participantes de organizações salafistas-jihadistas têm em seu passado algum envolvimento relevante com estudos religiosos, grande devoção à religião ou profundos conhecimentos acerca das escrituras islâmicas. O que move tais pessoas às atividades jihadistas, ao que se verifica, não se trata simplesmente de questões religiosas ou de ideologias a elas relacionadas, mas sim a motivos pessoais advindos de elementos emocionais e sociais (Cf. DE LA CORTE, 2007, p. 8). Como apresentam as pesquisas do antropólogo Scott Atran, os indivíduos atraídos por grupos jihadistas

estão ansiando por algo em sua história, em suas tradições, com seus heróis e sua moral; e o Estado Islâmico, por mais brutal e repugnante para nós e até mesmo para a maioria no mundo árabe-muçulmano, está se referindo diretamente a isso (...) $\mathrm{O}$ que inspira os agressores mais letais atualmente não é tanto o Corão, mas uma causa emocionante e um apelo à ação que promete glória e estima aos olhos dos amigos. $\mathrm{Na}$ verdade, poucos jihadistas têm algum conhecimento teórico sobre os textos corânicos ou teologia islâmica (ATRAN, 2015).

Considerando-se as questões ideológicas sociais hoje observadas no Oriente Médio, e mais especificamente no caso do Iraque e da Síria, tem-se que as análises aqui realizadas nesse campo condizem com a assertiva de Clemesha (2015), de que a exclusão e as parcas condições econômicas de grupos sociais árabes são um campo fértil para a exploração, recrutamento e propaganda por parte do Estado Islâmico. Neste sentido, fica patente que a carência econômica e a falta de perspectiva de vida que atingem grande parcela da população árabe compõem condições de aceitação e apoio ao Estado Islâmico, o qual percebe poucos obstáculos por parte das comunidades dos territórios em que se instalou. Ainda que determinados indivíduos ou grupos venham a discordar de seu posicionamento ou de sua conduta a respeito de determinados assuntos, isso não chega a se tornar um problema frente à aceitação - o que não necessariamente significa apoio maciça com que se depararam nos territórios conquistados, seja na Síria ou no Iraque.

\subsection{QUESTÕES POLÍTICAS LIGADAS AO SURGIMENTO DO ESTADO ISLÂMICO DO IRAQUE E DA SÍRIA}

Observar a forma como se deu a formação da organização em tela é de suma importância para se entender o equilíbrio de forças na região. A expansão do Estado 
Islâmico se deu não só territorialmente, mas também em quantidade de adeptos e de recursos, o que acabou por tirar da Al-Qaeda sua dominância no Iraque e na Síria. Tendo pouco tempo depois declarado a criação de um califado no Iraque, o Estado Islâmico do Iraque e da Síria passou a apresentar-se à comunidade internacional, incluindo-se aí os adeptos do salafismo-jihadismo, como uma alternativa à Al-Qaeda. Esta, a partir desse momento, passou a ser vista como incapaz de mudar o cenário que compôs durante anos, quando esteve representada pela sua ramificação iraquiana, encabeçada inicialmente por Al-Zarqawi e posteriormente por Al-Baghdadi. O Estado Islâmico do Iraque e da Síria, então, postou-se como uma organização mais capaz de atingir os objetivos salafistasjihadistas do que a Al-Qaeda, já que em poucos anos logrou maiores conquistas do que sua antecessora conseguiu em cerca de vinte anos (Cf. HOLBROOK, 2015, p. 93-4).

Apesar de o movimento salafista-jihadista não ser considerado como um fenômeno de um país específico, as situações sociopolítica e econômica, assim como os conflitos existentes no Iraque e na Síria, trazem bons exemplos do tipo de ambiente que mais frequentemente permitem o surgimento de grupos terroristas desse tipo. A situação corrente desses dois países tem muitos pontos em comum, e alguns deles podem ser identificados como fatores de influência para o surgimento de grupos salafistasjihadistas.

Uma vez que o Estado Islâmico se coloca como organização jihadista, há que se definir tal condição. Conforme Kushner (2003, p. 20), o grupo assim se define à medida em que se pauta na crença de que a utilização da violência contra não-muçulmanos se trata de uma importante missão religiosa. Dentro dessa visão, o Estado Islâmico elege a violência terrorista como instrumento para alcançar seus objetivos, tendo por meta restabelecer a ordem política e social através da lei islâmica, conforme sua interpretação fundamentalista. Esta lei caracterizaria uma sociedade islâmica unificada em um califado. Além disso, como a organização se baseia numa visão política do islamismo, ela não se atém somente aos objetivos de um estado convencional, o que permite entender que o Estado Islâmico pretende atuar não somente no Levante, mas também em qualquer lugar em que logre se instalar.

Milton-Edwards (2011, p. 112) faz uma interessante avaliação acerca da motivação dos grupos salafistas-jihadistas, afirmando que estes lutavam pela libertação, seja de seu povo, de sua ideologia ou da causa pela qual lutam. Seus inimigos podem ser as forças estrangeiras que estavam operando em seus países ou os árabes que foram 
apoiados por governos estrangeiros dispostos a estabelecer suas próprias regras nesses países. Independentemente de quem está oprimindo as sociedades às quais esses grupos pertenciam, eles serão vistos como inimigos. No caso de grupos fundamentalistas islâmicos, é comum notar a preocupação de se eliminarem outros muçulmanos que não pertençam à mesma seita, que não compartilham de sua ideologia, ou ainda aqueles que tenham cometido qualquer ato considerado ofensivo à sua interpretação do Islã. Dessa forma, nota-se que dentre os grupos terroristas que lutam pela libertação das suas sociedades - seja de ocupantes de origem ocidental, seja de árabes com mentalidade diferente - o elemento nacionalismo é comumente observado entre as suas ideologias. Considere-se que o senso de nacionalismo, para as sociedades árabes, como já disposto aqui, deve ser compreendido em um sentido muito mais amplo do que aquele geralmente concebido no ocidente. Analisando-se os grupos em questão, portanto, pode-se afirmar que há uma ligação clara entre os movimentos de libertação e o terrorismo atual, pois ambos os tipos de movimento compartilham de ideologias extremistas radicais (Cf. MILTON-EDWARDS, 2011, p. 112). Esta visão, em muitos aspectos, encontra concordância com Enzo Traverso (2019), o qual, ao traçar alguns paralelos entre a situação política atualmente verificada no Oriente Médio e a história do fascismo na Europa, percebe semelhanças entre o Estado Islâmico do Iraque e da Síria e o Fascismo Histórico europeu, mormente no que se refere à forte presença do elemento nacionalista. Utilizando-se inclusive do termo "fascismo islâmico" em suas considerações, o autor menciona que tal grupo politiza e radicaliza o fundamentalismo religioso de forma extrema. Contudo, mesmo que com tamanha importância conferida à religião, a organização permite a integração de ex-membros de um regime secular - os oficiais baathistas do antigo regime iraquiano - trazendo consigo assim um importante elemento nacionalista. Valendo-se do termo "nacionalismo sunita", Traverso propõe também que a cisão frente ao xiismo, explorada pelo grupo, é outro ponto em que se percebe o viés do nacionalismo por parte do Estado Islâmico, resguardadas as diferenças e conceitos entre tal grupo e o caso europeu, como enfatiza o autor.

No caso do Iraque, a história da construção moderna deste país seguiu o projeto pós-colonial do mundo em desenvolvimento. Começando no âmbito do imperialismo britânico no início do século XX, e através do processo histórico de descolonização e política da guerra fria, o Iraque constituiu-se numa república em 1958, para então se tornar uma ditadura em 1963. Este processo histórico, desigual e marcado por períodos de guerra, ditadura e privação, apresentou a continuidade de um projeto 
nacional, cuja infraestrutura social foi financiada pelo setor petrolífero público. Após a intervenção anglo-americana de 2003, este projeto histórico de construção do Estado - a consolidação da "iraquização" - foi interrompida abruptamente. Assim, sob a ocupação anglo-americana, o Iraque ficou marcado pela desconstrução da própria identidade nacional, dando forma ao ressurgimento de formações sociais reacionárias e atávicas como a base de um "novo" estado iraquiano. Considerando que os resultados da uma contínua mudança de regime são as consequências de um estado falido (Cf. ISMAEL e ISMAEL, 2004, p. 204), este processo histórico contribuiu para com que o Iraque chegasse a tal condição, uma vez que suas instituições não mais funcionavam de maneira a atender aos seus propositos. Foi criada a oportunidade para que se desestabilizasse o regime político iraquiano, se anulasse sua governança e se interrompesse qualquer tipo de projeto de poder eventualmente existente no país.

Percebe-se que a política americana para o Iraque provou ser um grande fracasso, devido, principalmente, a terem não só mantido, mas também fortalecido, a maior ameaça aos próprios americanos: os grupos fundamentalistas salafistas-jihadistas. Ou seja, tendo os Estados Unidos iniciado um conflito em razão da "guerra ao terror" alegando a posse de armas químicas de destruição em massa e à presunção de que Saddam Hussein financiaria grupos terroristas islâmicos - os americanos depararam-se, ao término da guerra convencional, com a ascensão de grupos insurgentes iraquianos que atuariam de maneira cada vez mais violenta. A política norte-americana para o Oriente Médio como resposta aos atentados terroristas perpetrados pela rede Al-Qaeda em 11 de setembro de 2001, acabaria por dar causa à maior tensão na história árabe moderna (Cf. ROGAN, 2009, p. 538).

O desenvolvimento da intervenção norte-americana de 2003 no Iraque trouxe a Al-Zarqawi as melhores condições para que seu grupo se fortalecesse e logo se consolidasse como representante da Al-Qaeda no Iraque. A morte de Al-Zarqawi demandou do conselho insurgente a formação do Estado Islâmico do Iraque, um novo grupo composto por diversos grupos insurgentes, mas cuja espinha dorsal continuavam sendo os integrantes da Al-Qaeda no Iraque. Pode-se notar nesse episódio uma forte questão sectária no país, fundamental para a formação do Estado Islâmico nesse território e para a indicação de seu líder mais proeminente nessa nova fase, Al-Baghdadi. Futuramente, a violência em meio à guerra civil na Síria ofereceria a Al-Baghdadi condições adequadas à expansão além das fronteiras iraquianas. Na ocasião, de forma a reconhecer e a contribuir para com o auxílio recebido por grupos sunitas sírios quanto ao 
financiamento e à logística para o Estado Islâmico no Iraque, este grupo enviou uma parte de seus combatentes ao país vizinho. $\mathrm{O}$ intuito desse movimento seria a criação de uma nova organização salafista-jihadista que contribuísse para com a campanha insurgente contra o governo sírio. Para liderar tal grupo foi designado Mohammed al-Julani, sírio integrante do Estado Islâmico do Iraque e que gozava da confiança de Al-Baghdadi desde a prisão de Camp Bucca. No espaço de um ano o grupo encabeçado por Al-Julani se estabeleceu como referência em meio à insurgência síria, denominando-se Jabhat AlNusra, o qual, inicialmente, não declarava possuir qualquer vínculo com a Al-Qaeda Central ou com o próprio Estado Islâmico do Iraque, postando-se como um grupo em grande medida independente. Assim, em meio ao conflito sírio, a Al-Nusra, a exemplo de outros grupos congêneres, dispunha de importantes fontes de financiamento do exterior, principalmente oriundas de doações, bem como podia contar com o fornecimento regular de material logístico, o que complementava a apreensão de equipamentos e outros recursos obtidos durante os combates. Como os grupos insurgentes não-islâmicos careciam de financiamento adequado, logo foram suplantados pelos grupos islâmicos (Cf. STERN e BERGER, 2015, p. 40-1), o que deixa clara a importância do financiamento externo para o surgimento do Estado Islâmico.

A integração dos antigos funcionários do regime baathista do Iraque aos quadros da Al-Qaeda no Iraque também possibilitou que se colocasse em prática a intenção política sunita de não permitir que um regime xiita ou curdo tomasse o poder no país, ainda que de forma democrática. Desse modo, o recurso à violência se apresentou como instrumento para que se perturbasse o processo político democrático que se desenvolvia no Iraque, servindo também como demonstração de poder, o que ensejaria uma nova distribuição de recursos políticos em meio à situação caótica em que se encontrava o país. Destarte, na tentativa de evitar que fossem relegados a uma posição claramente subalterna em relação a curdos e xiitas, os sunitas ligados à Al-Qaeda no Iraque se utilizariam da instrumentalização da violência de maneira recorrente e constante, mormente em sua forma terrorista, no intuito de levar o Iraque a uma guerra civil.

Este tipo de conflito se apresentava como uma saída interessante aos sunitas, já que sua participação num processo democrático não traria resultados positivos durante os processos eleitorais, tanto em razão da maioria xiita no Iraque quanto pela força política curda - principalmente devido à sua colaboração para com os representantes anglo-americanos então presentes no país. De fato, a vantagem de contar com muitos 
comandantes e oficiais experimentados, oriundos das forças armadas iraquianas do regime anterior, indicava uma importante vantagem militar na guerra civil que os sunitas insurgentes buscavam, dado o conhecimento da infraestrutura no campo logístico, de comunicações e de outros processos vitais a campanhas militares naquele território. Contavam ainda com o provável apoio de outros países simpáticos ao recém deposto regime baathista no Iraque. Os sunitas da Al-Qaeda no Iraque, segundo as avaliações de Diniz (2010, p. 206-7), tinham na guerra civil provavelmente sua única chance de sucesso na disputa pelo poder político naquele país, principalmente se conseguissem caracterizar o conflito como uma questão sectária, valendo-se da retórica de maneira a se colocarem como vítimas frente a xiitas e curdos, provocando a população que lhe era simpática a apoiar sua campanha e objetivos, quaisquer que fossem os meios de que se utilizassem.

Percebe-se que as crises econômicas experimentadas pela maioria da população do Iraque e da Síria criaram uma oportunidade para novas alternativas políticas nesses dois países. Concomitantemente, as oportunidades advindas do fenômeno da globalização - evidenciado pela própria Primavera Árabe - apresentaram às populações desses países novas alternativas políticas, tendo-se-lhes despertado o anseio por melhores condições de vida, num cenário em que a pobreza e a repressão por parte do governo constituído caracterizavam o quotidiano vivenciado pela população sunita nesses países havia décadas. Nessa esteira, organizações fundamentalistas islâmicas perceberam ótimas condições tanto para exercer influência como para expandir suas ramificações junto às mais diferentes instituições públicas e privadas. O desespero das massas se percebia em diversos países do Oriente Médio, e de forma muito significativa nos dois países ora estudados, o que se colocou como uma grande oportunidade ao desenvolvimento e à diversificação de organizações fundamentalistas islâmicas. Dessa forma, a Al-Qaeda no Iraque e a Frente Al-Nusra na Síria valeram-se da crescente inviabilização dos grupos de poder constituídos e de projetos sociopolíticos tradicionais. Apresentaram-se à população sunita desses territórios como opção de projeto político baseado em questões ideológicoreligiosas características ao fundamentalismo islâmico, através da ideologia salafista e de interpretações extremistas próprias do jihadismo (Cf. VISENTINI, 2014, p. 66-7). Os grupos que originariam o Estado Islâmico conseguiram notável e rapidamente explorar, com eficácia, as situações caóticas encontradas na Síria durante os conflitos resultantes da Primavera Árabe. Aliás, no caso do Iraque, anteriormente já haviam conquistado muitos dos seus objetivos ao explorar as falhas de um governo sectário naquele país (Cf. HOLBROOK, 2015, p. 101). 
Como expõe Fred Halliday, diferentes países no Oriente Médio - e ao que se percebe a situação da Síria e do Iraque se adequa exatamente nisso - sofrem as consequências da configuração geopolítica causada pelos ataques da Al-Qaeda em solo norte-americano em 11 de setembro de 2001. Ou seja, a pressão política sobre diversos governos de países árabes com relação a eventual apoio a organizações jihadistas fez com que a percepção de segurança fosse muito prejudicada. As próprias populações desses países passaram a sofrer uma crescente discriminação por parte da comunidade internacional, pois muitos as vincularam a integrantes da Al-Qaeda em função de questões religiosas ou étnicas, seja por puro desconhecimento ou pela divulgação de ideias propagadas por veículos de mídia de massa. Dentro dessa configuração, tanto iraquianos quanto sírios passaram a experimentar intensa ansiedade em função desse tipo de pressão (Cf. HALLIDAY, 2002, p. 32-3).

Contudo, independentemente dos acontecimentos externos, os regimes desses países vieram a explorar essa situação de ansiedade vinculada à baixa percepção de segurança. Avaliando-se esse cenário, pode-se identificar que tanto o governo iraquiano instituído pela coalizão encabeçada pelos Estados Unidos quanto o governo sírio de Bashar Al-Assad foram responsáveis por uma manipulação social de grandes proporções, logrando levar a cidadãos pertencentes a determinados grupos profundo sentimento de insegurança. Assim, dentro daquilo que coloca Halliday, a fase histórica atual no Oriente Médio, permeada por crises de diferentes tipos e por incertezas nas mais diversas esferas, não só favorecem como são exploradas de forma sórdida pela propaganda governamental. Dessa forma, os governos conseguiram criar consentimento por parte das próprias populações quanto a medidas repressivas praticadas pelos agentes do próprio Estado, o que viabilizaria, por conseguinte, a perseguição de opositores, rotulados convenientemente com definições que interessem ao Estado, assim justificando e legitimando a supressão de direitos civis e até o desencadeamento de conflitos externos e internos (Cf. HALLIDAY, 2002, p. 32-3).

Daí se permite compreender que existiram simultaneamente dois fatores causadores de grande instabilidade política. Primeiramente, constatou-se a existência do terrorismo de Estado no Iraque e na Síria, caracterizado pela percepção de insegurança, aliada a sentimentos de ansiedade e de tensão generalizadas provocados junto à população propositalmente por órgãos de comunicação que, em maior ou menor grau, possuíssem alguma forma de controle ou influência social. Aliado a isso se constatou a existência, nos dois países estudados, de organizações terroristas cuja atuação, no bojo da 
observações de Visentini (2014, p. 99), pode ser classificada como terrorismo comunitário, já que ocorre através de milícias formadas em meio à população civil, as quais intervém diretamente contra outras comunidades, geralmente minorias étnicas ou religiosas, havendo uma espécie de terror coletivo que visa à eliminação ou à expulsão destas. Nota-se, destarte, que no território do Iraque e da Síria houve a ocorrência simultânea desses dois fatores, os quais acabaram por se apresentar não só como o estopim para a conflagração de guerras civis em ambos os territórios, mas também para a expansão desses conflitos a ponto de as consequências ultrapassaram as fronteiras naturais desses países.

A Al-Qaeda no Iraque e a Frente Al-Nusra não só surgiram desses cenários como também cresceram rapidamente em função da gravidade desses conflitos. Potencializaram a internacionalização desses conflitos principalmente após a unificação desses grupos, ou seja, a fundação formal do Estado Islâmico do Iraque e da Síria. Esta nova organização veio a criar, de certa maneira, um contraponto à expansão xiita promovida pelo Irã no Oriente Médio. Aliás, como enfatiza Gerges,

o Estado Islâmico do Iraque e da Síria desenvolveu uma distinta identidade sectária pan-sunita, um contraste deliberado com a identidade pan-xiita representada pelos regimes sectários dominados pelo Irã em Damasco e Bagdá. De todas as variáveis que empoderaram o ISIS, o fator anti-xiita, anti-iraniano estão no topo da lista. O ISIS desenvolveu uma narrativa - enraizada numa identidade pan-sunita intrinsecamente oposta ao que retrata como uma ideologia pan-xiita, agressiva e expansionista - que havia se infiltrado e tomava conta do mundo islâmico. O programa anti-xiita e anti-iraniano do ISIS é sua carta mais eficaz no Iraque e na Síria, e já provou ser uma poderosa ferramenta de recrutamento (2016, p. 16-7).

A fusão em tela trouxe graves consequências tanto à Síria quanto ao Iraque, pois a partir desse momento a organização liderada por Al-Baghdadi aumentou consideravelmente os níveis de violência para promover sua expansão, seja ante os demais grupos insurgentes ou contra a população dos territórios por eles ocupados. Como enxerga Plebani, Al-Baghdadi "passou a adotar um modus operandi extremamente polarizado, baseado numa visão de 'conosco ou contra nós' e uma visão de mensagem islâmica profundamente hostil a qualquer outra interpretação" (2016, p. 13-4).

Um dos motivos para que o Estado Islâmico do Iraque e da Síria mantivesse o terrorismo como ferramenta pode estar relacionado à percepção de que nos conflitos havidos no Oriente Médio nos anos anteriores, os meios políticos não haviam sido 
suficientemente eficazes para se alcançarem mudanças sociais. Tal visão, como propõe Mark Gabriel (2015, p. 17-8), pode ser produto da atuação da Irmandade Muçulmana durante os protestos no Egito durante a Primavera Árabe.

Quando do surgimento do Estado Islâmico do Iraque e da Síria, já em meio à Guerra Civil Síria, tal grupo poderia ter alterado sua forma de atuação com relação à busca pelo poder naquele território. Contudo, tal conflito se dava já nos estágios mais avançados dos movimentos sociais provocados pela Primavera Árabe, ou seja, já se conhecia então o resultado do movimento em diversos outros países da região. Em razão dessas observações, pode-se perceber importante influência do resultado da Primavera Árabe havida em território egípcio, mormente por envolver de maneira significativa a Irmandade Muçulmana, organização que compartilha muito da ideologia de que o Estado Islâmico é partidário. A liderança do Estado Islâmico pode ter percebido, quando do início de sua campanha na Síria, o desfecho do movimento social no Egito e as consequências para a Irmandade Muçulmana. Neste caso, após a mudança do governo egípcio em razão de um movimento que contou com a participação de representantes das forças armadas e da própria Irmandade Muçulmana, esta última foi anulada politicamente pelas forças armadas quando da assunção do novo governo.

Este caso trata-se de um exemplo insucesso da tentativa de uma organização fundamentalista islâmica de chegar ao poder na esteira da Primavera Árabe, ou pelo menos tornar-se mais relevante dentro das disputas pelo poder por vias democráticas. Os resultados da Primavera Árabe no Egito, desse modo, podem ter levado a liderança do Estado Islâmico a tornar-se ainda mais extremista, deixando de considerar toda e qualquer tentativa de chegar ao poder no Iraque e na Síria de forma pacífica e por vias unicamente políticas. Qualquer tipo de transformação social que o Estado Islâmico visasse promover, portanto, teria de ser obtida através do uso da violência, incluindo-se o terrorismo (Cf. GABRIEL, 2015, p. 35). O próprio envio de Al-Julani para a formação da Frente $A l$ Nusra Síria pode ser indicativo de que os planos de Al-Baghdadi para tomar o poder na Síria descartavam toda e qualquer medida que se referisse a um processo democrático. É possível também entender que, mais do que uma motivação para que a liderança do Estado Islâmico mantivesse a prática de atos terroristas, o caso da Irmandade Muçulmana pode ter levado Al-Baghdadi a recrudescer ainda mais a violência perpetrada por seu grupo, convicto de que esta seria a única forma de obter sucesso em sua empreitada. 
As análises ora realizadas com relação à esfera política vêm de encontro ao proposto por Hanne e De La Neuville (2015, p. 18), os quais mencionam que as medidas de Nuri al-Maliki, eleito presidente do Iraque - ressalvas feitas às condições em que se deram as eleições logo após a Guerra do Iraque - não foram o suficiente para conduzir o país a uma unificação, permitindo ainda que o caos se instalasse no país, de modo que certos grupos sociais fossem oprimidos enquanto outros eram beneficiados. Tal entendimento indica condição similar ao observado no contexto do governo de Bashar Al-Assad, no sentido de que este também não foi capaz de manter a unidade da sociedade síria, bem como não pôde conter a insatisfação popular com seu governo. A própria eclosão da Primavera Árabe e o alastramento da insurgência sunita evidenciam isso. A situação política do Iraque e da Síria teria apresentado um vácuo no poder de fato, apresentando um cenário favorável para que o Estado Islâmico se formasse e explorasse tal hiato com o objetivo de chegar ao poder.

Isto configurou-se como uma janela de oportunidade para o início das atividades da organização que mais tarde viria a se denominar Estado Islâmico. A realidade síria, quando dos inícios das atividades da Frente Al-Nusra, era muito similar à iraquiana quando da formação do grupo por Al-Zarqawi. Ademais, na esfera política, a fusão entre a Frente Al-Nusra e o então Estado Islâmico do Iraque, para que então se formasse a organização ora estudada, constituiu-se no aproveitamento de janelas de oportunidade em razão do caos socioeconômico e do vácuo de poder político de facto existente nesses dois países.

\subsection{FINANCIAMENTO AO ESTADO ISLÂMICO DO IRAQUE E DA SÍRIA}

O financiamento das organizações salafistas-jihadistas, como é o caso do Estado Islâmico do Iraque e da Síria, é fator relevante pois sem isto nenhuma instituição poderia se manter ou expandir. Embora essa necessidade possa parecer demasiado óbvia, neste caso não é tão simples, já que financiar grupos terroristas envolve, além de extenso aparato logístico, questões tanto políticas quanto jurídicas. No entanto, a ideologia tem um papel importante que faz com que países, instituições e até mesmo pessoas físicas venham a financiar grupos terroristas de cunho salafista e jihadista. A ideologia do salafismo é fator-chave para angariar apoio para o financiamento de tais grupos. Por isso, 
dentre os maiores apoiadores de grupos do tipo está o Estado da Arábia Saudita, o qual patrocina diversas instituições islâmicas, já que o país apoia oficialmente o wahhabismo como sua forma de Islã sunita, a ponto de adotar essa ideologia como instrumento político do Estado (Cf. MARQUADT e HEFFELFINGER, 2008, p. 184). De acordo com o entendimento de Noam Chomsky (2017) no que se refere à ideologia wahhabita-salafista, a riqueza e a cultura missionária da Arábia Saudita fazem desta o principal centro de radicalismo dentro do mundo muçulmano, inclusive além de suas fronteiras. Segundo o autor,

dentre os Estados islâmicos, a Arábia Saudita ocupa a dianteira, com ampla margem, no quesito de maior patrocinadora do terror islâmico, não somente graças ao financiamento direto com o dinheiro de sauditas abastados e outros no Golfo como, mais ainda, pelo fervor missionário com que os sauditas promulgam sua extremista versão wahhabitasalafista do islã por meio de escolas corânicas, mesquitas, clérigos e outros meios disponíveis para uma ditadura religiosa com a colossal riqueza do petróleo. O ISIS (Estado Islâmico do Iraque e do Levante ou Estado Islâmico do Iraque e da Síria) é um rebento extremista do extremismo religioso saudita e da instigação da chama jihadista (CHOMSKY, 2017, p. 278-9).

Por outro lado, organizações não governamentais que também financiam organizações terroristas o fazem através da $z a k a t^{24}$, elemento obrigatório dentro do islamismo, tendo-se como exemplos órgãos financiadores de instituições de caridade na Arábia Saudita e dos Emirados Árabes Unidos (Cf. LAPIDUS, 2014, p. 885).

Ainda como Al-Qaeda no Iraque, o grupo que mais tarde se constituiria no Estado Islâmico já contava com um extenso e organizado sistema de financiamento que garantia o pleno funcionamento da organização. É claro que os recursos existentes nos territórios ocupados pelo grupo geravam capital que seria utilizado não somente para sua subsistência, mas também para viabilizar sua expansão. Esta deve ser entendida não só em sua forma territorial, mas também através do crescimento do número de apoiadores principalmente por meio da propaganda ideológica, como visto. Para tanto, fazem-se necessárias atividades diversas dentro da organização, cada uma com atribuições específicas, à semelhança de um Estado efetivamente constituído, conforme as acepções

\footnotetext{
${ }^{24}$ Do árabe, "doação às almas.” Trata-se de doação de cunho religioso, obrigatória aos muçulmanos adultos, compreendendo $2,5 \%$ da riqueza pessoal a ser paga anualmente a sua autoridade religiosa. No caso dos xiitas, estes também devem contribuir com um quinto do excedente de sua riqueza (Cf. MARTIN, 2004, p. 754).
} 
já estabelecidas neste trabalho. Dentre as atribuições diversas do grupo encontrava-se aquela responsável pelo controle e execução de atividades financeiras. Diante da situação de ilegalidade de suas atividades em meio à grande maioria da comunidade internacional, o Estado Islâmico teve de adequar suas operações financeiras a essa realidade. Uma vez que não poderia receber transações financeiras aberta e legalmente dentro do sistema financeiro internacional, o que também a impedia de realizar remessas dentro desse sistema, a organização necessitou se adequar a esse cenário, de modo a garantir transações financeiras seguras que possibilitassem o financiamento ao autodenominado Estado, ou, no caso, califado.

A Al-Qaeda no Iraque já se valia de um núcleo de angariação de fundos que tinha por função solicitar dinheiro junto a uma vasta lista de simpatizantes e apoiadores do grupo, de forma que se tornassem doadores regulares. Desde o início de suas atividades, a Al-Qaeda possuía na área do Golfo Pérsico seu maior grupo de doadores principalmente na Arábia Saudita, terra natal de Bin Laden -, ainda que contassem como indivíduos e organizações em diversas partes do globo financiando-a diretamente. $\mathrm{O}$ aporte monetário de que dispõe a organização salafista-jihadista se vale de mecanismos tradicionais realizados entre muçulmanos. Assim, torna-se viável a movimentação financeira sem se utilizar recursos formais, pautando-se somete na confiança pessoal. Denominada hawala, ${ }^{25}$ este meio de transação financeira, bastante arraigado dentre diferentes comunidades islâmicas, permite que não se mantenham registros junto a instituições financeiras formais, ou de outras formas que pudessem ser posteriormente detectáveis ou rastreáveis. No caso de seus apoiadores, suas doações de capital foram plenamente conscientes quanto à motivação da solicitação financeira da Al-Qaeda no Iraque e do destino final do dinheiro. Em que pese diversos apoiadores terem alegado desconhecer a destinação efetiva dos recursos disponibilizados, nunca deixaram de remetê-los, o que indica que de fato apoiavam a causa da Al-Qaeda no Iraque (Cf. DINIZ, 2010, p. 200). Daí se pode perceber, uma vez mais, a eficácia da disseminação ideológica levada a cabo por anos pelo grupo salafista-jihadista que sempre visou se tonar a representante do islamismo militante internacionalmente.

25 Também chamado de hundi. Trata-se de método informal de transferência de valores entre muçulmanos, no qual não se utiliza instituição bancária regular, tampouco registros quaisquer referentes às transações realizadas (Cf. WEINER, 2001, p. 3). 
Atendo-se à análise da hawala com mais pormenor, dada a relevância desta no sistema de financiamento de que o Estado Islâmico se utilizou, tal mecanismo pode ser entendido como um sistema de transferência monetária baseada na informalidade, que teria surgido como uma alternativa por parte de organizações terroristas frente às consequências impostas pela comunidade internacional após os atentados de 11 de setembro de 2011 (Cf. GOEDE, 2003, p. 513-532). Ao que se pode avaliar, o desenvolvimento dessa forma de movimentação financeira tem pouco a ver com questões religiosas, pois não abrange qualquer elemento próprio do Islã em sua prática ou concepção, como se poderia acreditar inicialmente. Na realidade, tal prática em muito se assemelha a transações financeiras clandestinas por parte de grupos criminosos em diferentes países. Ademais, há registros de que a hawala seria um sistema bancário colocado em prática justamente para que as organizações classificadas como terroristas por diversos países pudessem continuar recebendo seus financiamentos e procedendo às suas operações (Cf. DINIZ, 2010, p. 200).

Ao se analisarem as origens desse sistema em âmbito do Oriente Médio, entretanto, podem estas ser relacionadas às redes comerciais - tanto formais quanto informais - já utilizadas na região desde a expansão imperialista europeia. Ou seja, desde a época em que Iraque e Síria encontravam-se na condição de colônias franco-britânicas. Nessas circunstâncias, tais redes de comércio acabavam por ser de extrema importância àqueles que não possuíam acesso a instituições bancárias convencionais e a sistemas financeiros regulares (Cf. GOEDE, 2003). Isto se compara de certa forma à realidade atual do Iraque e da Síria, nos quais, em muitas regiões, a deficiente economia tenta se manter em meio a guerras civis e a constantes embargos impostos por Estados estrangeiros. Nesses ambientes, a informalidade ganha força em meio ao comércio em geral. A experiência dessas sociedades, portanto, subsiste, repetindo-se na atualidade as práticas de outrora.

Mesmo assim, há que se observar que as redes de hawala não se colocam à margem de todo o sistema financeiro formal desses territórios, até porque não possui sistema de crédito. Caso se mantivesse totalmente em apartado das redes e instituições regulares, as organizações que se utilizam da hawala não teriam qualquer tipo de garantia de segurança econômica. Destarte, a rede em tela encontra-se interligada, ainda que de modo tênue, junto aos sistemas financeiros convencionais, operando numa espécie de zona cinzenta da economia. Esta realidade da economia local leva a se enxergá-la como uma espécie de sistema híbrido, ou seja, composto tanto pela rede informal, dispersa pelo 
território e impossível de ser acuradamente contabilizado, quanto pela rede convencional, baseada em operações formais. Dentre estas podem-se mencionar grandes instituições bancárias internacionais, como o francês Crédit Lyonnais, o alemão Commerzbank, o Saudi Holland Bank (subsidiária saudita da firma holandesa ABN Amro Bank) e também o norte-americano Western Union Financial Services. Perfazendo-se uma ulterior análise a respeito da maneira como os integrantes do Estado Islâmico têm de operar dentro da realidade da hawala, tem-se que este grupo se vale da confiança, lealdade e vínculos sectários característicos das relações interpessoais que devem embasar e viabilizar transações desse tipo. Tais valores e condições remetem, novamente, às características da ummah, cujos valores religiosos e ideológicos conectam pessoas e grupos de modo a garantir o pleno funcionamento desse tipo de rede, para a qual a questão da confiança é fundamental (Cf. MAURER, 2005, p. 59-61).

Depreende-se, ao se analisar a utilização da hawala, que não obrigatoriamente a globalização demanda aparatos tecnológicos de comunicação e informação para que se extraia proveito desse fenômeno. Os líderes do Estado Islâmico, aliás, não só souberam manobrar com eficiência sua organização frente às transformações impostas pelo avanço da globalização, mas também tiveram inteligência suficiente para identificar as vantagens da utilização de métodos ortodoxos mesmo em meio às novas realidades do mundo de hoje. O aproveitamento da hawala para levar a cabo o financiamento de sua organização como um todo provou-se eficaz ante a necessidade de se lidarem com fiscalizações crescentes de toda sorte de transações financeiras impostas pelo sistema bancário regular mundialmente (Cf. CRONIN, 2002-2003, p. 50-1). Os riscos que este sistema bancário lhes traz, indubitavelmente, serviram de estímulo à inovação por parte da organização salafista-jihadista, cuja liderança, cônscia de que diversos países e instituições lhes causariam inúmeros problemas ao rastrear suas transações. Destarte, o Estado Islâmico teve de se valer das oportunidades apresentadas pela precariedade das instituições estatais dos países em que operavam inicialmente, entre outras questões. Por exemplo, a exploração da porosidade das fronteiras entre a Síria e o Iraque junto aos países limítrofes se apresenta como forma de acesso a colaboradores, com o intuito de se realizarem as transações financeiras baseadas no hawala, assim como a organização também poderia facilmente encaminhar seus agentes ao exterior.

Além disso, as rotas comerciais regulares, que também se tornavam mais permeáveis conforme o avanço dos conflitos no Oriente Médio - mais notadamente as guerras civis nos dois países supracitados - são outra maneira de se empregarem as 
atividades inerentes ao hawala. Tais rotas comerciais, muitas das quais incluem total ou parcialmente atividades ilegais operadas por grupos criminosos diversos há séculos, também se apresentam como janela de oportunidade ao Estado Islâmico. Colaboração e negociações junto a grupos criminosos, frise-se, nunca foram um empecilho ao Estado Islâmico - eis outra herança da Al-Qaeda -, vindo a se tornar uma atividade bastante lucrativa e em expansão. Conforme descreve Cronin (2002-2003, p. 50-1), os valores financeiros oriundos de transações junto ao crime organizado transnacional compõem um volume ainda maior do que aquele realizado por meio do hawala, e tão difíceis de se rastrear quanto aqueles movimentados através da hawala. Nesta questão específica, observa-se que o Estado Islâmico não trouxe qualquer inovação, pois transações junto ao crime organizado transnacional já ocorriam antes do surgimento do Estado Islâmico, em diferentes países e conjunturas.

Dentro de uma visão mais ampla, considerando-se o crescente contato entre as organizações criminosas transnacionais e grupos terroristas - valendo aqui novamente a perspectiva instrumental - pode-se depreender, nas palavras de Paul Pillar, que

o quadro estratégico amplo, no entanto, é de uma capacidade crescente
de organizações terroristas para explorar as mesmas vias de
comunicação, coordenação e cooperação como outros atores
internacionais, incluindo Estados, corporações multinacionais,
organizações não-governamentais, e até mesmo indivíduos. Seria
ingênuo supor que o que é benéfico para o comércio internacional e a
comunicação internacional não seria igualmente benéfico para os
terroristas (2001, p. 48).

Portanto, com o intuito de otimizar e prover maior segurança às transações que garantiriam seu financiamento, o Estado Islâmico valeu-se de uma atividade utilizada pela Al-Qaeda - a hawala -, mas também manteve seus contatos arraigados havia tempos junto ao crime organizado transnacional. Através disto, aliás, garantia seu acesso a armas e equipamentos diversos que dificilmente obteria fora do mercado negro. A Al-Qaeda no Iraque obtinha grande sucesso em conseguir tais fundos, principalmente durante o mês sagrado para os muçulmanos, o Ramadã. Outra forma notável de arrecadação de valores se deu através de líderes religiosos em mesquitas espalhadas no Oriente Médio e na Europa, mas com especial menção àquelas situadas no sudeste asiático. Nestes casos, os 
$i m \tilde{a} s^{26}$, como de praxe, conseguiam maiores volumes de dinheiro valendo-se da obrigatoriedade de os muçulmanos em realizar doações como princípio religioso, o zakat, o qual, como indica também Gómez, se constitui num importante meio de financiamento de organizações terroristas islâmicas (2010, p. 7).

A caridade é um dos princípios fundamentais da religião islâmica, e todos aqueles que possuírem certa quantia de dinheiro são obrigados a pagar o zakat, o que compreende 2,5\% de tal montante, anualmente, seja da poupança, seja de ativos. Além da obrigatoriedade quanto ao zakat, as escrituras islâmicas prescritas no Corão e a própria tradição islâmica sugerem a realização de contribuições voluntárias, denominadas Sadaqah, que devem ser destinadas aos muçulmanos mais necessitados. A maioria dos cidadãos muçulmanos realizam o pagamento desse tipo de contribuições, destinando-o tanto a instituições de caridade islâmicas quanto à mesquita de sua preferência (Cf. GÓMEZ, 2010, p. 9). Estas instituições, por sua vez, utilizam tais contribuições para financiar uma vasta gama de atividades de cunho religioso, bem como de ações humanitárias e sociais, sendo que normalmente tais pagamentos são realizados por instituições financeiras islâmicas no lugar de seus clientes (Cf. LONE, 2016, p. 8). Contudo, casos de corrupção de pessoas que pertencem a entidades como as citadas, ou ainda de pessoas que tenham sido cooptadas através de radicalização ideológica principalmente com relação ao salafismo ou ao jihadismo - apresentam-se como exemplos de formas como esses intermediários servirão aos propósitos de organizações terroristas. Tais mecanismos de cooptação foram comumente utilizados por organizações islâmicas diversas, não sendo a Al-Qaeda e o Estado Islâmico uma exceção nesse sentido.

De qualquer forma, quanto ao empenho de tais imãs para com a angariação de valores, percebe-se um maior empenho e contribuição daqueles que compartilham - e, obviamente, difundem - dos ideais salafistas, o que significa que conscientemente contribuíam para com movimentos islâmicos radicais, postando-se como militantes. Importante constatar que os coletores de fundos se utilizam muitas vezes de contatos junto a organizações não-governamentais de caridade legal e legitimamente constituídas. Valem-se do apoio de organizações formais e de instituições legítimas para fornecer

\footnotetext{
26 Dentro da tradição xiita, trata-se da autoridade suprema legitimamente constituída de determinada comunidade muçulmana, como por exemplo os quatro primeiros profetas, que se seguiram a Maomé. Esta figura equivale à do califa, na tradição sunita. Como o Estado Islâmico e as organizações a ele ligadas inserem-se na tradição sunita, o termo imã deve ser entendido como o líder religioso de uma congregação muçulmana, ou seja, uma figura comumente formada em teologia, habilitada a conduzir as orações da comunidade (Cf. DEMANT, 2004, p. 224, e SILVA, 2016, p. 24).
} 
cobertura a suas operações financeiras e atividades de coleta de fundos. Avaliando-se estes métodos de financiamento, pode-se notar que a conciliação de variados métodos de angariação de fundos possibilitou à Al-Qaeda do Iraque a construção de uma vasta e eficiente rede de recursos financeiros, a qual se espalhou a diversos países islâmicos, principalmente junto a comunidades islâmicas fora do Oriente Médio (Cf. GÓMEZ, 2010, p. 7).

O método utilizado desde a Al-Qaeda no Iraque foi a infiltração de funcionários a instituições de caridade com a finalidade última de desviar dinheiro dos programas humanitários e sociais legitimamente realizados por tais entidades, para assim financiar suas próprias atividades ilegais. Apesar do sucesso em obter fundos originários desse esquema, a Al-Qaeda desenvolveu sua estratégia de aquisição de fundos, vindo a criar sua própria rede de instituições de caridade, garantindo assim cobertura de modo a obter divisas diretamente, excluindo, a utilização de intermediários e de agentes de terceiros.

Dentre tais redes de contribuições financeiras pode ser citada, com especial referência devido à sua importância, a Organização Internacional de Socorro Islâmico, sediada na cidade saudita de Jeddah, reconhecida como uma das maiores instituições de coordenação de caridade islâmica. Ainda que a maior parte das atividades por ela administradas sejam dedicadas a programas religiosos, educacionais, sociais e humanitários, várias de suas organizações filiais têm sido utilizadas para financiar a AlQaeda, ainda que por vezes contribuidores aleguem ignorância quanto a tal condição. Situação semelhante ocorre com a Fundação Islâmica Al-Haramain, cuja sede também fica na Arábia Saudita, que se coloca como uma organização privada com objetivos ligados à caridade e à educação. Contudo, tal organização foi apontada como responsável pelo aporte financeiro e material à Al-Qaeda e suas subsidiárias. Acusação similar também recai sobre a Sociedade de Renascimento da Herança Islâmica, sediada no Kuwait e que conta com diversas subsidiárias em diferentes países (Cf. GÓMEZ, 2010, p. 8-9). Estes mecanismos possibilitaram ao grupo manter um fluxo contínuo de altos valores, sendo que as fontes de capital operavam independentemente entre si. Isto é, em caso de alguma das fontes não ter condições de remeter divisas à Al-Qaeda do Iraque, certamente outras garantiriam o fluxo financeiro externo ao grupo.

A utilização de empresas de fachada e de empresas financeiras denominadas offshore, objetivando a proteção tanto de pessoas físicas quanto jurídicas ligadas ao 
financiamento das atividades terroristas do Estado Islâmico representou, desde o seu surgimento, um grande problema às entidades que buscavam regular as transações comerciais internacionalmente. $\mathrm{O}$ fato de estas se encontrarem registradas em centros financeiros extraterritoriais se constitui em um complicador. Como exemplo de organizações que se enquadram nessas características podem-se citar as corporações internacionais de negócios, as quais têm por escopo justamente a criação de complexas estruturas financeiras. Estas podem contar com a participação do portador de valores e não têm a obrigatoriedade de publicar suas contas. Dadas as peculiaridades desse tipo de corporações, nota-se que as mesmas apresentam grandes atrativos aos investidores que busquem o anonimato para suas transações e operações financeiras diversas, ou ainda àqueles que queiram efetivar suas movimentações de valores além dos limites estipulados legalmente (Cf. GÓMEZ, 2010, p. 11). As possibilidades ofertadas por tais offshore serviram indubitavelmente aos propósitos do Estado Islâmico, o qual se valeu do anonimato dos operadores de suas contas, mesmo que eventualmente utilizando-se de terceiros, mediante o uso desse tipo de empresas. Enquanto o Estado Islâmico não se tornou o centro das atenções junto à mídia internacional e das agências de inteligência e outros serviços de contraterrorismo, houve à organização salafista-jihadista campo aberto para movimentar suas divisas, realizar investimentos, transações comerciais e, sobretudo, receber vultoso financiamento externo. Os valores necessários para que a organização operasse e prosperasse, portanto, estavam garantidos.

Seguindo o modo de operação da Al-Qaeda, o Estado Islâmico teve êxito em substituir doadores por indivíduos e organizações desconhecidas das autoridades. Contudo, observam-se importantes diferenças entre a forma de financiamento entre ambas as organizações. No caso do Estado Islâmico, este teve a capacidade de construir um modelo econômico autossuficiente, dispondo do controle territorial que obteve ao longo de suas campanhas na Síria e no Iraque. Tal condição, diferentemente do que a AlQaeda lograra atingir, permitiu que o Estado Islâmico se posicionasse como um ator independente, colocando-se, ao menos regionalmente, quase que como um estado constituído de fato. Esta questão, bastante controversa, permitiu que muitas pessoas e instituições, principalmente as simpatizantes à causa salafista-jihadista, vissem no financiamento da expansão de um estado islâmico - observe-se a correlação entre o significado do termo e o nome da organização em si - algo como um empreendimento de sucesso junto ao qual tinham a oportunidade de tomar parte (Cf. OKTAV, DAL e KURS,UN, 2018). 
A mencionada autossuficiência advinha da exploração de recursos naturais como minérios, petróleo e produtos agrícolas, bem como de capitais oriundos de atividades industriais e comerciais. Atendo-se à questão do comércio de petróleo especificamente, percebe-se que o grupo realizava transações comerciais externas também. Isto denota que muito do financiamento obtido pelo Estado Islâmico vinha de instituições e estados formalmente constituídos, já que a comercialização desse tipo de matéria-prima demanda um conglomerado de recursos indisponíveis a pequenas empresas ou a corporações que não estejam de alguma maneira vinculadas a um estado soberano, seja para fins de operação ou de regulamentação. Para exemplificar a relevância do petróleo para a garantia das finanças do Estado Islâmico, pode-se anotar que até meados de 2014 o grupo já operava 60\% dos campos petrolíferos em território sírio, tendo vendido cinquenta mil barris só na Síria no mercado negro (Cf. OKTAV, DAL e $\mathrm{KURS}_{3} \mathrm{UN}$, 2018, p. 11). Este ponto evidencia, uma vez mais, a aceitação e reconhecimento do Estado Islâmico externamente, em meio a muitas comunidades muçulmanas, como consequência de suas propostas político-religiosas contidas em sua propaganda ideológica.

A exploração dos territórios da Síria e do Iraque também se valeu de produtos de caráter religioso e cultural, o que gerou ao grupo considerável quantia de dinheiro, como deixa claro o empenho da organização no tráfico de antiguidades. Para tanto, como indica Helga Turku (2018), serviram-se de saques a museus e diferentes cidades históricas, algumas até consideradas patrimônios da humanidade, contando com a cooperação com organizações criminosas transnacionais e seus intermediários. A exploração da própria população local acabou por ser um recurso do qual a organização não abriu mão, dentro de sua estratégia de exploração de todos os recursos que os territórios dominados pudessem oferecer. Feitas as conexões com o crime organizado transnacional, o Estado Islâmico contribuiu para com o envio de mercadorias ilícitas a qualquer lugar do mundo, obtendo assim altas somas em dinheiro. O empenho do Estado Islâmico no tráfico de bens de propriedade cultural foi, portanto, significativo para o aumento de suas reservas financeiras (Cf. TURKU, 2018, p. 7-10).

A partir do momento em que o Estado Islâmico garantiu sua autos sustentabilidade, deixou de depender do auxílio de grandes doadores como ocorrera anteriormente, principalmente quando ainda mantinha a forma de administração herdada da Al-Qaeda. Dado que seu financiamento provinha em grande medida de fontes existentes em seus próprios territórios, eventuais problemas relacionados aos Estados, 
instituições e pessoas no exterior não mais se constituiriam em um problema para a organização, ao menos no campo financeiro. Dentre os países que comporiam o grupo de doadores regulares do Estado Islâmico, estão a Arábia Saudita e o Qatar (Cf. OKTAV, DAL e KURS „UN, 2018, p. 11). Isto apresenta um importante nível de independência do Estado Islâmico no campo financeiro, tornando-se até menos suscetível às crises econômicas no Oriente Médio. A distribuição das receitas do Estado Islâmico, nessa nova configuração, passou a provir primeiramente da venda de materiais de origem ilícita, seguida de um número reduzido de doadores externos e de empresas criminosas. A diminuição de doadores, ou ao menos dos montantes enviados por estes ao Estado Islâmico, pode ser explicada pelo esforço da comunidade internacional quanto a inibir o financiamento de organizações terroristas. Tanto Estados quanto empresas passaram a ter suas remessas de ativos mais fiscalizadas e controladas, o que se tornou um notório obstáculo a remessas financeiras de grande volume destinadas ao Estado Islâmico.

No que concerne à relação entre a conquista territorial e o volume de recursos financeiros do Estado Islâmico, tem-se que tal expansão permitiu o acesso tanto a uma maior quantidade de recursos naturais quanto às rotas e mecanismos que viabilizavam o comércio desses recursos. Ou seja, o acesso aos recursos naturais por si só não foi significativo para a organização, uma vez que para prosseguir com a expansão de seus projetos necessitava de continuamente aumentar seus recursos, e, para tanto, dependia da comercialização desses insumos. Essa lógica ficou bastante evidente nos territórios iraquianos dominados pela organização, onde obteve um rápido avanço em razão de ter tido a oportunidade de fazer intenso uso das rotas de mercado negro e de contrabando que já eram utilizadas desde os tempos do regime de Saddam Hussein. O acesso às rotas do mercado negro no Oriente Médio, mais especificamente aquelas próximas às fronteiras do Iraque e da Síria, foram um ponto chave para a progressão financeira do Estado Islâmico durante seu crescimento. Isto evidencia o estreito vínculo entre a questão territorial e o acesso a recursos naturais, cuja exploração, por óbvio, visava incrementar as condições financeiras do grupo. Isto permite afirmar, por conseguinte, que quanto mais territórios se conquistavam, maiores se tornavam os recursos financeiros do Estado Islâmico (Cf. OKTAV, DAL e KURS „UN, 2018, p. 12), fator este estreitamente ligado à rápida expansão territorial que caracterizou sua evolução.

É notável também a capacidade que o Estado Islâmico demonstrou de diversificar os seus métodos de obtenção de divisas para financiar suas operações. A liderança do grupo soube explorar as oportunidades que lhe surgiam com relação aos 
investimentos diversos, e, quando poucas opções possuíam, tiveram a capacidade de criar novas saídas. Em diversos casos demonstraram seus líderes serem capazes de se adaptar a novas conjunturas econômicas e a diferentes configurações geopolíticas, como ficou patente na associação do Estado Islâmico a organizações criminosas transnacionais. Nesse cenário, realizou uma leitura acurada das oportunidades apresentadas nos locais em que passavam a operar (Cf. DINIZ, 2010, p. 200).

Analisadas as questões acima, pode-se determinar que o modelo econômico utilizado pelo Estado Islâmico é substancialmente diferente daquele empregado pela AlQaeda no Iraque, o qual se pautava exclusivamente nas doações por parte de distintas fontes, mas que jamais dispuseram de recursos próprios. Ou seja, o Estado Islâmico logrou tornar-se autossuficiente, característica que jamais uma entidade infra estatal de sua natureza apresentara, ainda mais uma classificada como terrorista por quase que a totalidade dos Estados que compõem a comunidade internacional. Eis aqui uma importante característica do Estado Islâmico, que notadamente o colocou em um outro patamar quando comparado com outras organizações salafistas-jihadistas. Há ainda outro diferencial por parte essa organização que se pode extrair das observações aqui feitas. Como já apontado por Oktav et al (2018), também foi o Estado Islâmico na contramão da forma mais básica de financiamento praticada por outros atores violentos não-estatais no Oriente Médio, ou seja, deixou de ser dependente de patrocinadores estatais, de doadores ou da corrupção e manipulação de representantes de organizações de caridade. O Estado Islâmico, na realidade, passou a envolver-se com um número significativo de empresas criminosas no Iraque e na Síria (Cf. OKTAV, DAL e KURS,UN, 2018, p. 11-2).

Isto significa que a liderança da organização, dentro de sua estratégia maior, abandonou uma postura que pode ser definida como passiva, na qual tinha de aguardar o financiamento externo ficando à mercê de oscilações de mercado de diferentes materiais, de dificuldades enfrentadas por operadores financeiros ou até mesmo pelo combate ao terrorismo regional e mundialmente. Passou a apresentar uma postura mais ativa, através da qual o grupo logrou chegar à autossuficiência, o que não só viabilizou um crescimento deveras célere das atividades dependentes de volumoso aporte financeiro, como também deixou seu aporte logístico imune às dificuldades enfrentadas por entidades estatais ou sub-estatais. Destarte, o grupo alterou o tabuleiro político regional, tendo se consolidado como uma organização salafista-jihadista de características únicas, notoriamente em razão de autossuficiência. 
Atendo-se especificamente ao Oriente Médio, vê-se que no caso dos países que não mantinham vínculos com o Estado Islâmico passaram a enxergar no Estado Islâmico um concorrente em alguns campos. No nível econômico, a expansão do mercado negro, a intensificação do uso de rotas de contrabando e até o fortalecimento de organizações criminosas transnacionais que operam no Oriente Médio desequilibraram as relações dessa natureza na região. Já no que tange às relações de poder, mormente no campo da segurança internacional, tiveram de reinventar suas formas de atuação frente ao Estado Islâmico no combate ao financiamento de organizações terroristas, já que nunca haviam se deparado com organização que possuísse as capacidades apresentadas pelo grupo em questão. Estas condições caracterizaram o aspecto financeiro do Estado Islâmico positivamente, o que explica em parte seu rápido crescimento, servindo, inclusive, de chamariz para novos integrantes internacionalmente em razão das boas condições de que dispunha e oferecia.

Por fim, as análises concernentes ao apoio financeiro e logístico recebido pelo Estado Islâmico servem de suporte fático ao estipulado por Oktav et al (2018, p. 11-2), os quais mencionam que, em que pese não haver um país que oficialmente patrocine o grupo, verifica-se ter existido um vasto financiamento por parte de ricos donatários de países como Kuwait, Arábia Saudita e Qatar, bem como oriundo de muçulmanos europeus. O apoio político, logístico e econômico advindo de Estados constituídos e outras entidades, baseados em diferentes interesses, veio a favorecer e a viabilizar o desenvolvimento da organização a ponto de se equiparar a um Estado formalmente constituído.

\subsection{QUESTÕES MILITARES LIGADAS AO SURGIMENTO DO ESTADO ISLÂMICO DO IRAQUE E DA SÍRIA}

Logo após a intervenção norte-americana ao Iraque, enquanto os líderes políticos depostos com a queda do regime de Saddam Hussein e outras figuras de alto escalão daquele governo eram procurados pelas forças regulares ocidentais, iniciaram-se duas formas de resistência militar no território iraquiano. Segundo indica Visentini (2014), uma delas, muito significativa, tratava-se dos agentes do governo deposto - em sua esmagadora maioria oriunda da população iraquiana sunita -, o que incluía oficiais 
das forças armadas, agentes de inteligência e policiais, os quais possuíam não só experiência como conhecimento suficientes para que passassem a integrar milícias e a promover sua expansão. Assim, angariaram novos membros e organizaram novos grupos paramilitares para lutar contra o novo governo que se formava. A outra forma de resistência se originou de militantes fundamentalistas islâmicos, advindos de grupos diversos já formados no país, ainda que nem todos seus integrantes tivessem experiência em conflitos armados. A estes se somaram grandes quantidades de apoiadores oriundos de outros países do Oriente Médio (Cf. VISENTINI, 2014, p. 110-1).

É neste ponto que se verifica que a relevância do grupo liderado por AlZarqawi, o qual foi capaz de se tornar referência dentre outros grupos insurgentes no Iraque. O modo de atuação característico do Estado Islâmico, como aponta Reilly (2016, p. 157), se manifesta através de extrema violência não só durante suas ações militares, mas também ao executar a lei islâmica - ou aquilo que seus integrantes entendem como tal. Incluem-se dentre as vítimas cidadãos muçulmanos, que também têm sofrido com bárbaras execuções sumárias diante das comunidades às quais pertencem. Seus prisioneiros, capturados durante combates ou sequestros, são executados com o desígnio de difundir o medo, dada a violência e naturalidade observados nessas ocasiões. Essa difusão, aliás, é planejada e registrada nos mínimos detalhes, contando com filmagens de qualidade profissional e divulgação em várias páginas na internet.

Em que pese ter Al-Zarqawi deixado extenso legado em meio ao grupo que liderava, sua morte traria novos rumos à organização. Inevitavelmente, as novas lideranças trariam mudanças tanto procedimentais quanto ideológicas ao grupo. Portanto, além de Al-Zarqawi, o comando de Al-Baghdadi também merece ser destacado e analisado. O grupo comandado por este último foi capaz de vários feitos considerados improváveis a um ator não-estatal. Conseguiu dominar uma área que foi desde o noroeste da Síria até o leste do Iraque. Contudo, a vastidão territorial não é o mais relevante, mas sim a capacidade de ter criado as fundações análogas a um Estado formalmente constituído - daí o nome utilizado, o qual explicita inclusive as aspirações de AlBaghdadi. Tais conquistas demonstraram o grande empenho e o parcial sucesso em transformar o Estado Islâmico em um modelo estatal para muitos muçulmanos. A partir de então a organização passou a postar-se como o bastião da luta contra comunidades e governos contrários à sua ideologia e à sua cultura, visando, ao final, a reunião da comunidade islâmica global - a ummah -, de forma a restaurar um modo de vida nos moldes dos registros referentes à época da fundação do Islã pelo profeta Maomé. 
A utilização da extrema violência pelo Estado Islâmico se destacou também na esfera militar, já que esta não só se tornou importante característica do grupo em meio aos outros grupos insurgentes, mas também o distinguiu durante os conflitos armados de que tomou parte. O uso do terrorismo fazia com que as forças regulares iraquianas e sírias evitassem o combate com o Estado Islâmico, temendo que em caso de derrota fossem vítimas de cruéis atrocidades. Tal condição contraria todas e quaisquer legislações e protocolos internacionais referentes à participação em conflitos e à manutenção de prisioneiros de guerra. Ademais, a experiência e o conhecimento militar por parte do alto escalão do Estado Islâmico lhes permitiam combater em condições de igualdade frente a seus opositores, num cenário que, dentro de uma perspectiva militar, pode ser equiparada ao envolvimento de duas forças militares convencionais. Dentro da importância do uso indiscriminado da violência, há que se avaliar em que isto se pauta. Podem ser identificadas, conforme proposto por Gerges (2016, p. 10), pelo menos três motivos que poderiam explicar a prática da violência exacerbada pelo Estado Islâmico. Vejamos.

Inicialmente, tem-se as origens do grupo como parte da Al-Qaeda no Iraque e a figura do seu fundador, Al-Zarqawi. Este, ícone da geração salafista-jihadista pós-AlQaeda - ou seja, cuja atuação se deu após o declínio das operações da Al-Qaeda internacionalmente em decorrência da já mencionada "guerra ao terror" -, valia-se de uma política que se pautava sobremaneira na questão identitária e comunitária. Isto é, sua forma de liderança priorizava a criação e a manutenção de uma identidade única e particular de seu grupo, propósito para o qual a instrumentalização da violência, elevada a níveis incomuns até dentre outras organizações terroristas, serviu como elemento identitário do Estado Islâmico. Mais do que isso, manter o grupo como uma comunidade com leis e valores próprios - dentro dos quais se encontram a aceitação e a prática dos níveis extremados da violência em função de seus objetivos ideológicos - colaborou para com a coesão do grupo.

Um segundo motivo apontado pelo autor pode ter sido a iraquização do grupo, quando de sua fase inicial, por meio da instrumentalização dos meios comumente utilizados pelos integrantes do partido Baath para a repressão de seus opositores. Além disso, é válido observar o extenso legado de violência no Iraque hoje em dia. Aqui se expõe uma característica da sociedade iraquiana atual, a qual experimentou ao logo das últimas décadas grandes provações, vivenciando crises econômicas, guerra, terrorismo e escassez de meios de subsistência diversos. Ou seja, a grande maioria dos indivíduos recrutados pelo Estado Islâmico do Iraque havia sido endurecida pelas precárias 
condições de vida com que estavam habituados. Portanto, estes estariam aptos a compartilhar dos ideais da organização e a viver sob seus preceitos. Gerges (2016) esclarece que a "iraquização" da organização não foi uma questão de escolha, mas sim de necessidade, em função tanto da escassez de adeptos estrangeiros, os quais inicialmente não eram bem aceitos pelos insurgentes iraquianos. Isso fez com que o Estado Islâmico, nas suas fases iniciais, se fechasse cada vez mais aos estrangeiros, distanciando-se da organização que procurava emular - a Al-Qaeda Central -, tornando-se assim "mais localizada, mais provinciana e hiper sectária" (GERGES, 2016, p. 148). Note-se que estas características são observadas no período anterior à formação do Estado Islâmico do Iraque e da Síria. Após seu surgimento, a expansão do grupo e as necessidades daí advindas passaram a demandar uma acentuada internacionalização do grupo. Contudo, esta não será escopo deste trabalho, haja vista se tratar de período posterior ao surgimento da organização que é objeto de pesquisa.

O terceiro motivo indicado por Gerges se trata da origem rural da massa de integrantes do Estado Islâmico, o que se intensificou conforme se dava a dominação das comunidades nos territórios sobre os quais a organização avançava. $\mathrm{O}$ aumento do número de integrantes com essa característica pode ser visto como consequência da expansão inicial do Estado Islâmico em áreas que não compreendiam grandes zonas urbanas do Iraque e da Síria, justamente onde havia menos oportunidades de emprego e as condições de vida eram bem mais árduas. Em situações extremas, é comum que muitos populares sejam cooptados a integrar grupos salafistas-jihadistas por verem nestes melhores condições de vida do que aquelas que experimentavam em meio a conflitos armados. Este é um aspecto comum em territórios em graves crises econômicas e sociais, como no caso dos dois Estados supramencionados. Isto denota que, para o Estado Islâmico, as populações rurais lhes apresentavam características mais favoráveis, podendo então ser mais bem manipulados (Cf. GERGES, 2016, p. 273).

A relevância do Estado Islâmico, entretanto, não se encontra somente nas dimensões daquilo que angariou - territórios, adeptos, dinheiro, até admiração e respeito - mas também nas dimensões de tudo o que afastou de si. Criou, nas mesmas proporções de suas conquistas, imensa rejeição, múltiplos inimigos e ampla oposição, que se assomavam à vastidão de forças antagônicas aos seus objetivos e métodos, inclusive dentro da própria comunidade islâmica (Cf. PLEBANI, 2014, p. 3-4). Sua estratégia de converter os muçulmanos xiitas em alvo, chegando até a rotulá-los com apóstatas, acabou por criar, ao longo do tempo, uma ferrenha resistência por parte da comunidade xiita. A 
magnitude das consequências disso, aliás, tomou proporções que aparentemente não foram consideradas inicialmente pela liderança da então Al-Qaeda no Iraque. Ao estabelecer a população xiita iraquiana e síria como alvos dos inúmeros atentados terroristas realizados pela organização, constatou-se a mesma lógica que já se vinha notando nos conflitos no Oriente Médio. Isto é, os conflitos sectários internos no Iraque, que logo evoluíram à condição de guerra civil, passaram a ser caracterizados por uma guerra por procuração, tendo o Irã - principal centro do xiismo no Oriente Médio passado a apoiar de várias formas as milícias xiitas que atuavam nos territórios iraquiano e sírio.

O empenho iraniano no conflito estudado indica a que nível chegou a guerra civil síria. Ainda que num primeiro momento tal conflito envolvesse somente grupos internos que lutavam pelo governo da Síria, logo atores externos se envolveram na disputa pelo poder, dada a importância desse país para a conjuntura política no Oriente Médio. No entanto, a falência do Estado sírio também motivou atores externos a buscar obter naquele território alguma vantagem política, ainda que através de grupos agindo por procuração, como o supramencionado caso do Hezbollah, atuando em favor do Irã, e do próprio Estado Islâmico do Iraque, ao enviar seu representante à Síria para liderar um grupo objetivando subjugar o regime de Al-Assad. Dentro de uma perspectiva mais ampla, nota-se que a Al-Qaeda veio a perceber uma janela de oportunidade nas guerras civis em curso no Iraque e na Síria, tendo-se inserido em ambos os cenários de forma análoga. Nestes casos, utilizou-se da mesma estratégia político-militar de empenhar grupos armados por procuração, como feito há muito tempo por Irã e pela Arábia Saudita. Assim, a atuação da Frente Al-Nusra na Síria acabava por significar, em grande medida, a presença da Al-Qaeda na Síria, enquanto no caso do Iraque o próprio nome do grupo adotado por Al-Zarqawi - Al-Qaeda no Iraque - indica essa realidade.

Comparando-se as capacidades bélicas e logísticas entre os grupos armados operando nos dois países, fica evidente que inicialmente os grupos insurgentes possuíam capacidades muito inferiores àquelas apresentadas pelas forças regulares que enfrentavam. A utilização do terrorismo, nessa conjuntura, pode ser vista como a única forma que os grupos insurgentes encontraram para obter algum sucesso no campo militar. Os atos terroristas promovidos por tais grupos acabaram por lhes garantir algum sucesso nas primeiras fases das guerras civis em que estiveram envolvidos, haja vista os vastos territórios que conseguiram conquistar e as continuadas investidas de forças regulares que logrou dissuadir. 
Além das fronteiras da Síria e do Iraque, as consequências da atuação do Estado Islâmico vieram a alterar de maneira profunda o equilíbrio de forças do Oriente Médio, que já apresentava grande instabilidade nas últimas duas décadas. O Estado Islâmico causou grande impacto na política, na economia e até mesmo em aspectos da visa religiosa em diversos países do Oriente Médio. As frágeis e porosas fronteiras da maioria dos países árabes, uma herança do esfacelamento do Império Otomano após a Primeira Guerra Mundial, em 1918, sempre afetaram a relação de poder e provocaram conflitos entre as nações da região, como se mantém até os dias de hoje. Isso foi largamente explorado pela nascente organização salafista-jihadista, numa avaliação atinente à questão política regional. Já na esfera global, vê-se que o Estado Islâmico também demonstrou ter potencial para estender seu poder de influência no Ocidente, ainda que como um ator não-estatal, principalmente em países europeus, em razão do grande número de adeptos e colaboradores estrangeiros (Cf. PLEBANI, 2014, p. 4).

A estrutura organizacional apresentada pelo Estado Islâmico, que reflete sua operacionalização, se constitui de forma bastante descentralizada. A utilização de ferramentas proporcionadas por diferentes tecnologias de informação e de comunicação, principalmente se valendo do acesso e da plena utilização da rede mundial de computadores, lhe proporciona capacidade de execução e de controle de tarefas variadas, o que, por conseguinte, lhe confere condições de operar de forma mais rápida e coordenada. Como identifica Cepik (2010, p. 125), há características essenciais às redes terroristas atualmente para que possam operar descentralizadamente, como conexões densas no núcleo dirigente - o que envolve alta confiança entre líderes e agentes dos demais escalões, mecanismos fortes de vinculação, e também insulamento -, conexões esparsas entre as células, a autonomia operacional por parte destas em relação à liderança, e ainda o alto grau de flexibilidade operacional. No caso do Estado Islâmico, sua capacidade de financiamento, de recrutamento e de realizar atentados demonstram que tal organização se vele do mesmo tipo de estrutura. A descentralização foi, portanto, elemento crucial para o desenvolvimento tanto de suas capacidades como de sua influência no Oriente Médio. Ademais, essa característica provou-se fundamental para o recebimento de financiamento através de células, indivíduos, organizações e grupos diversos espalhados por diversos países.

O terrorismo observado atualmente é um componente orgânico da guerra assimétrica, que é o tipo de conflito que de fato se observa nesta primeira década do século XXI, tendo tido como marco inicial justamente os atentados terroristas de 11 de setembro 
de 2001 nos Estados Unidos. Este tipo de conflito se pauta em duas características importantes às quais o Estado Islâmico se enquadra. Primeiramente, tem-se o uso de meios políticos e econômicos para fins militares (Cf. CEPIK, 2010, p. 126). No caso da organização ora analisada, observa-se que a capacidade militar adquirida desde o início das ações de insurgência levou-a ao ponto de se equiparar à condição de forças militares regulares. Concomitantemente, desde suas fases iniciais o grupo nunca deixou de atuar no campo político, sendo que a interferência junto à população sunita - por ocasião das eleições para a presidência do Iraque e quando do referendo, por exemplo - deixa claro o empenho do Estado Islâmico nessa esfera. O aproveitamento das oportunidades políticas percebidas por ocasião de enfraquecimento dos governos sírio e iraquiano, os quais fragilizaram o equilíbrio sociopolítico em ambos os países, também evidencia a visão política da liderança do Estado Islâmico.

Além disso, Al-Zarqawi e Al-Baghdadi comprovaram ter capacidade de realizar avaliações precisas no nível político internacional. Isto ficou claro quando da percepção de ambos acerca da confluência de interesses de Estados terceiros com relação ao apoio à insurgência sunita no pós-guerra no Iraque, e também quanto à eclosão dos conflitos que levariam à guerra civil no caso da Síria. Ambos os casos são exemplos de ocasiões em que forças irregulares sunitas e xiitas foram apoiadas por países alinhados a linhas ideológicas antagônicas e conflitantes entre si, dando-se uma disputa pela tomada de poder nesses dois países que refletem a disputa política em nível regional.

Outra importante característica do Estado Islâmico que o insere no conceito de guerra assimétrica consiste na assimetria dos meios e na limitação dos fins (Cf. CEPIK, 2010, p. 126). Aqui percebe-se que o Estado Islâmico - fazendo-se novamente ressalvas quanto à utilização de tal nome - jamais possuiu os mesmos meios e recursos de que os Estados formalmente constituídos dispunham para subsistir a longo prazo, manter sua população e seu território. Sua capacidade militar inferiorizada em relação à grande maioria dos Estados existentes ao redor dos territórios que dominava, por conseguinte, forçaram o Estado Islâmico a adotar estratégias tipicamente terroristas como forma de fazer frente às forças militares adversárias. Entretanto, tais ações muitas vezes recaíram sobre alvos civis, o que demonstra que o Estado Islâmico ultrapassou os limites impostos legalmente a qualquer tipo de conflito armado.

No que tange à limitação dos fins, denota-se que o objetivo maior do Estado Islâmico não poderia ser comparado àquele de um Estado já constituído, até porque o 
grupo fundamentalista islâmico não se caracterizava como tal. Isto, basicamente, afasta a propositura dos fins que teria nesse caso. Os objetivos do governo iraquiano e sírio, em contraste, eram principalmente de se manter a soberania de seus territórios, de defender suas populações e até de manter seus regimes governamentais. Lutaram, portanto, pela manutenção do status quo, ainda que estes fossem alvo de reiteradas críticas por parte da comunidade internacional, em cada época e em seus respectivos contextos. Esta realidade, aliás, reforça ainda mais a questão da atuação política do Estado Islâmico, apontado no parágrafo anterior. Portanto, o objetivo final da organização fundamentalista islâmica de criar um Estado formal na região do Levante de forma alguma pode ser entendido efetivamente como tal. A assimetria do conflito, portanto, também nesse ponto, se faz notar.

Tornando à questão da utilização de métodos terroristas por parte em meio a um conflito assimétrico, Martha Crenshaw (1998, p. 13) identifica dois importantes fatores podem ser relacionados ao uso do terrorismo: o sentido de urgência e a oportunidade política percebida pela liderança organizacional. Tais elementos seriam perceptíveis quando determinada organização percebe que a adoção de processos formais pode ser prejudicial à consecução de seus objetivos em razão do tempo que isso poderia levar, motivo pelo qual visa a acelerar tais processos através da prática do terrorismo.

O primeiro fator se trata da identificação da pressão externa de um competidor. No caso do grupo liderado por Al-Zarqawi, depreende-se a forte influência da Al-Qaeda Central e de outros grupos insurgentes iraquianos. No caso da Al-Qaeda Central, esta detinha não só atenção internacional como também, na visão de muitos, admiração por sua atuação e objetivos. Surge a necessidade, então, de se destacar dos demais competidores em meio à insurgência iraquiana, o que o grupo liderado por AlZarqawi logrou conseguir. Isto asseverou a seu grupo uma admiração crescente que se traduziu, como ficou claro, numa maior capacidade de conquistar adeptos. Mesmo tendo a organização passado a se denominar Al-Qaeda no Iraque, a Al-Qaeda Central nunca deixou de lhe fazer sombra. Ou indica que sempre se caracterizou como um competidor de fato. A utilização do terrorismo por Al-Zarqawi e por Al-Baghdadi, em níveis de violência superiores à Al-Qaeda Central, pode indicar que isto se tratou, paralelamente a outros motivos e necessidades, de uma maneira de se destacar e até de enfrentar o histórico e o status que detinha a Al-Qaeda no Iraque. 
Durante a insurgência observada na Síria pode-se enxergar como competidor do Estado Islâmico, além da retromencionada Al-Qaeda Central, a própria Frente $\mathrm{Al}$ Nusra - a qual mais tarde viria a ser integrada ao Estado Islâmico. Uma vez que a AlNusra conquistara vastos territórios dentro da Síria e demonstrara ter obtido amplo apoio por parte de sírios e estrangeiros, tornava-se necessário ao Estado Islâmico apresentar-se como um competidor mais forte, o que significaria para a opinião pública - dentro do universo de indivíduos e instituições sunitas que fossem, abertamente ou não, simpatizantes e seguidores do salafismo-jihadismo, enfatize-se - se constituir em uma opção mais viável em meio ao grande número de grupos que atuavam contra o regime de Al-Assad. Como se pôde observar, as capacidades do Estado Islâmico em manter uma campanha com base em atentados terroristas permitiu-lhe se firmar como uma opção relevante não só aos potenciais seguidores, mas também à própria Frente $A l$-Nusra, que em meio a sua campanha de insurgência acabou por se fundir com o Estado Islâmico do Iraque. A esta questão deve ser dada a devida importância, uma vez que, em meio a tal movimento, a liderança da Al-Nusra teve de abrir mão de sua aliança prévia com a AlQaeda Central, bem como renegar seu forte elemento nacionalista, os quais serviam de motivação para seus seguidores (Cf. CRENSHAW, 1998, p. 13).

Já ao se ponderar sobre eventual janela de oportunidade mencionada no segundo tópico, assinala-se, no caso do Iraque, que a contínua campanha militar dos aliados dos norte-americanos, na primeira fase do conflito, apresentou-se como uma oportunidade para se utilizar da violência em sua forma terrorista, visando impedir sua expansão no Iraque. Num segundo momento, tem-se que as eleições democráticas ocorridas no Iraque também se apresentaram como oportunidade de se aplicar tal método, desta vez contra a população xiita, com o desígnio de inibir a participação desta junto à nova conjuntura política que se formava, pautada em processos democráticos. Além disso, aproveitou Al-Zarqawi para desestabilizar politicamente o Iraque valendo-se de questões sectárias contra a democracia. Já na Síria, pode-se depreender que a fragilidade do governo de Bashar Al-Assad frente à insurgência, marcada por diversas derrotas em combate e pelo grande número de simpatizantes do salafismo-jihadismo, se coloca como uma formidável janela de oportunidade. Assim, entende-se que o Estado Islâmico passou a obter sucesso efetivo com seus atentados terroristas em solo sírio, o que causou constantes recuos por parte das tropas regulares sírias e a necessidade de estas solicitarem apoio estrangeiro, notadamente do Irã e da Rússia (Cf. CRENSHAW, 1998, p. 13). 
Por fim, as análises realizadas quanto à condição militar e suas capacidades operacionais nesse campo vêm a suportar as explicações de Sekulov $(2014$, p. 27) de que a organização se tornou um exército possuidor de um poder maior do que aquele de qualquer outro grupo terrorista do Oriente Médio, inclusive a própria Al-Qaeda, tendo dentre seus quadros oficiais experimentados oriundos do exército iraquiano sunita de Saddam Hussein. A formação militar dos líderes da organização e a experiência de seus integrantes durante as guerras civis no Iraque e na Síria proporcionaram-lhes condições de manter recursos humanos e logísticos capazes de enfrentar forças militares de Estados formalmente constituídos, assim favorecendo e possibilitando sua expansão territorial. 


\section{CONSIDERAÇÕES FINAIS}

O surgimento do Estado Islâmico do Iraque e da Síria em meio à história árabe contemporânea exige que seja estudado sob diferentes aspectos. Como visto no presente trabalho, tanto os aspectos internos à organização quanto sua evolução em meio às sociedades iraquiana e síria merecem escrutínio para se compreender seu surgimento.

É certo que o fator ideológico-religioso tem grande importância, pois, como seu viu, o salafismo e o jihadismo são características comuns a muitos grupos islâmicos fundamentalistas. Contudo, se percebe que a ideologia com base religiosa não se constitui em um fim para sua atuação, mas sim como um meio utilizado pela liderança do Estado Islâmico para fins de recrutamento, controle organizacional e propaganda. As inúmeras críticas oriundas de diferentes instituições islâmicas acerca da interpretação por parte da liderança do Estado Islâmico do Iraque e da Síria quanto aos preceitos islâmicos expressadas as suas interpretações do salafismo e do jihadismo - denotam o quão deturpada é sua visão ideológico-religiosa. A abordagem do grupo quanto a esses elementos limita sua representação a somente uma pequena parcela, e extremamente radical, do islamismo. Suas ações, portanto, indicam uma instrumentalização da religião e suas ideologias para fins políticos.

Já no que se refere ao aspecto socioeconômico no cenário em que surgiu o Estado Islâmico do Iraque e da Síria, é importante apontar que as sociedades árabes da Síria e do Iraque, consideradas sociologicamente como "sociedades de vergonha"27, enfrentam graves situações socioeconômicas atualmente. Esses fatores, conjuntamente, constituem-se em uma combinação perigosa da perspectiva psicossocial. A partir dessa lógica, é evidente que tal conjuntura pode transformar grupos fundamentalistas islâmicos em abrigos perfeitos àqueles que sofreram grandes perdas de ordem econômica ou social, mantendo poucas perspectivas para vidas. Restando a tais indivíduos somente a vergonha e os valores sociais com os quais foram educados, a recuperação de suas antigas condições sociais torna-se a prioridade em suas vidas. Em muitas regiões do Iraque e da Síria, durante o período aqui analisado, integrar a uma organização como o Estado Islâmico do Iraque e da Síria tornou-se, para muitos cidadãos, a única forma de garantir a

\footnotetext{
${ }^{27}$ Conforme conceito de Evelin Lindner (2006) abordado no item 3.4.1 desta dissertação.
} 
sobrevivência. E a organização em tela, por sua vez, acabou por depender em muito de indivíduos nessas condições para garantir sua existência, o que fica evidente ante a observação de todo o empenho do grupo em impedir o sucesso de processos democráticos no Iraque e na Síria.

Ainda nessa esteira, cabe constatar que Evelin Lindner (2006), ao correlacionar a geopolítica aos conflitos havidos desde o início deste século no Oriente Médio, anteviu, ainda em 2006, que o conflito se alastraria caso o mundo árabe - e não somente os cidadãos iraquianos e aqueles que com eles se identificam - visse a ação militar norte-americana como uma invasão humilhante. Como consequência disso, haveria dentre essas sociedades um sentimento de raiva crescente que poderia levar a retaliações na forma de "terrorismo contra o Ocidente", nas palavras de Lindner (2006, p. 32). Nesta perspectiva, esse é o significado quando terroristas se referem a "ganhar não apenas a guerra, mas também a paz” (2006, p. 32).

No campo político, o surgimento do Estado Islâmico do Iraque e da Síria pode ser entendido como fruto do desenvolvimento histórico dos eventos recentes em países árabes. Pode-se identificar como fator crucial para o surgimento do Estado Islâmico a crise de governança e de políticas econômicas observadas há décadas no Iraque e na Síria (Cf. GERGES, 2016, p. 7; NEWMAN, 2007, p. 145). O Estado Islâmico apresenta-se assim como reflexo da histórica intervenção externa no Oriente Médio e resultado de uma desastrosa tentativa de mudança de regime no Iraque (2003). Ademais, trata-se de um sintoma de condutas políticas dos governos iraquiano e sírio que acabaram por se tornar prejudiciais à maioria de suas populações. Segundo Gerges (2016), isto resultou no desgaste e na deslegitimização de instituições estatais, bem como na expansão das guerras civis originadas da Guerra do Iraque em 2003 e da Primavera Árabe na Síria em 2011. Tal crise de governança foi justamente o que levou estes países a se caracterizarem como Estados falidos, oportunidade na qual o Estado Islâmico se colocou como alternativa para muitos indivíduos que procuravam segurança, explorando assim as incertezas e os descontentamentos sociais (Cf. SCUPIN, 2016, p. 410). Tanto seu surgimento quanto sua expansão têm estreita relação com as más condições socioeconômicas e políticas das sociedades em que se inseriu, o que foi potencializado pelas rivalidades étnico-religiosas que ainda se verificam nesses territórios. Ademais, as disputas políticas de cunho regional e global também viabilizaram em grande medida sua expansão, inserindo-se nesses países grupos armados combatendo por procuração, conforme os interesses de algumas potências do Oriente Médio. 
A figura de Al-Zarqawi também tem grande peso em seu desenvolvimento. O papel deste foi além de ter lançado as bases da organização que mais tarde se tornaria o Estado Islâmico do Iraque e da Síria. Sua relação com a Al-Qaeda, referência dentre as organizações salafistas-jihadistas já àquela altura, apresentou-se digna de nota devido à sua colaboração para com o projeto de Osama Bin Laden em território iraquiano, viabilizando a esta organização passar a operar num país em que ainda não possuía representantes. Al-Zarqawi foi o líder que permitiu à Al-Qaeda usufruir das oportunidades apresentadas pelo pós-guerra a partir de 2003, tendo, ao mesmo tempo, garantido ao seu próprio grupo robusto aporte financeiro e logístico sem o qual provavelmente não lhe teria sido possível um crescimento tão rápido. A influência do primeiro líder da Al-Qaeda no Iraque foi fundamental para a cultura organizacional, para a manutenção da ideologia salafista-jihadista e para a forma de atuação terrorista do futuro Estado Islâmico do Iraque e da Síria. Seu legado acabou por servir também de combustível ideológico para que seus sucessores rompessem relações com a própria AlQaeda. A imagem de Al-Zarqawi - da qual se valeria inclusive o futuro líder Al-Baghdadi - portanto, ainda que outrora tenha significado à Al-Qaeda um valioso aliado na expansão da ideologia salafista através da chamada "jihad global” - resguardadas as interpretações peculiares a esses grupos, frise-se -, acabou por significar posteriormente a revolta contra Osama Bin Laden e seu grupo, em razão do sentimento de independência em meio a seus integrantes e a divergências ideológicas e operacionais em relação à Al-Qaeda (Cf. GERGES, 2016, p. 57, 129). A ideologia propagada pelo Estado Islâmico se coloca como uma evolução à atuação propagandística e à retórica utilizadas pela Al-Qaeda, provando ser uma adaptação à globalização e à realidade tecnológica do século XXI. Como resultado, o Estado Islâmico passou a ter o status de maior organização salafista-jihadista em atividade globalmente, o que ficou evidente a partir do momento em que diversos grupos do Oriente Médio, do norte africano e do sudeste asiático passavam se aliar ao Estado Islâmico (Cf. HUNT, 2005, p. 105). O carisma e o legado de seu primeiro líder também podem ser apontados como fatores fundamentais para o surgimento e a coesão do grupo.

As possibilidades tecnológicas de informação e comunicação também foram cruciais no contexto histórico no qual se desenvolveu o Estado Islâmico. A hábil utilização das oportunidades que lhe conferiram os inúmeros veículos de mídia garantiu à organização uma rápida e consistente inserção tanto no campo político internacional quando no ideológico (Cf. DERIAN, 2010, p. 329-30). A competente exploração de tais 
tecnologias, aliás, também se observa quanto ao eficaz financiamento obtido pelo grupo. Quando da impossibilidade de se utilizar da tecnologia moderna, entretanto, a organização soube operar formas rudimentares, contudo eficazes, de transação e transporte de recursos destinados à organização.

$\mathrm{Na}$ esfera militar, o grupo apresentou condições de enfrentar com sucesso outros grupos insurgentes, bem como forças militares regulares graças ao conhecimento e à experiência de seus integrantes, muitos oriundos do regime de Saddam Hussein. Essas condições possibilitaram uma grande capacidade de enfrentamento de seus inimigos durante as campanhas de expansão territorial. Nas ocasiões em que se inseria em conflitos assimétricos, a utilização de táticas terroristas pelo Estado Islâmico também se mostrou fundamental para sua expansão territorial.

É fundamental entender que a fragmentação política e social do Oriente Médio atual foi causada por um processo histórico. Dentro de uma análise mais ampla, os problemas dessa natureza observados no Iraque e na Síria são fruto de diferentes intervenções estrangeiras ocorridas desde o fim da Segunda Guerra Mundial, em 1945 (Cf. VIOTTI e KAUPPI, 2013, p. 131) As mazelas causadas por regimes políticos das últimas décadas nesses países, onde sentimentos contrários ao neocolonialismo são muito fortemente percebidos, pavimentaram o desenvolvimento do fundamentalismo islâmico, panorama justamente no qual se insere o Estado Islâmico do Iraque e da Síria (Cf. LEWIS, 2004; BARR, 2008, p. 323). Este explorou também o sentimento de nacionalismo e o anseio pela independência das populações desses países em relação às novas formas de dominação ocidental (Cf. GELVIN, 1997). Consequentemente, o surgimento do Estado Islâmico no Iraque e sua posterior expansão à Síria são mais do que óbvios exemplos de um ordenamento político incerto nesses dois países, caracterizados por profunda crise de governança. São ainda reflexo das complexidades que processos de democratização podem trazer ao Oriente Médio atualmente, mormente em função das experiências advindas da Primavera Árabe (Cf. BAUER, 2015, p. 40). Numa comparação teórica entre as revoltas sociais em meio a que o Estado Islâmico se inseriu e o fascismo europeu do século XX, Enzo Traverso (2019) afirma que "tanto o terrorismo islâmico quanto o fascismo clássico são formas de revolução conservadora ou modernismo reacionário." Essa visão corrobora o pensamento de Martha Crenshaw (1998) de que a utilização de táticas terroristas pode servir como um meio para se obter vantagem política ou se alcançar um objetivo político, ao se produzir mudança na postura política dos governantes responsáveis pelas decisões relativas a determinada comunidade. Portanto, foram 
elementos cruciais para o surgimento do Estado Islâmico do Iraque e da Síria a fragilidade do sistema de governança nesses países em decorrência dos processos históricos recentes (Cf. GERGES, 2016, p. 3, 170).

Finalmente, cabe apontar, como ficou aqui demonstrado, que à medida em que o termo terrorismo se refere a um método de atuação, e admitimos que seu emprego é frequentemente motivado politicamente, também entendemos que outros atores, inclusive estatais, incorrem em ações e atuações de cunho terrorista, ainda que não sejam assim classificadas por motivos igualmente políticos. A fragilidade, assim, não é tanto do termo, como daqueles que o empregam. No caso do Estado Islâmico do Iraque e da Síria, ao longo desta dissertação, vimos sua derrocada e retração - a partir de 2017 - mas não sua eliminação. Enquanto isso, os fatores históricos que levaram ao seu surgimento, bem como a conjuntura política, econômica e social que favoreceram sua origem continuam aguardando pelo desenvolvimento e à espera de respostas minimamente condizentes com a gravidade da situação no Oriente Médio. 


\section{BIBLIOGRAFIA}

ABUHANIEH, H. M. The Islamic State Organization. The Sunni Crisis. Amã: Friedrich-Ebert-Stiftung Jordan \& Iraq, 2015.

ABUKHALIL, A. Al Qa'ida. In: ABUKHALIL, A. Encyclopedia of the Middle East and North Africa. $2^{a}$. ed. Farmington Hills: MacMillan Reference, v. III, 2004. p. 1865-1866.

ALEXANDER, K.; ZUHUR, S. Iraqi Insurgency. Event Date: 2003-Present. In: TUCKER, S. The encyclopedia of Middle East wars: the United States in the Persian Gulf, Afghanistan, and Iraq conflicts. Santa Barbara: ACB Clio, v. II, 2010. p. 615-9.

AL-QAZZAZ, A. Iraq. In: MATTAR, P. The Encyclopedia of the Modern Middle East and North Africa. 2a . ed. Farmington Hills: MacMillan Reference, v. II, 2004. p. 1129-1136.

ANZALONE, C. Mahdi Army. In: TUCKER, S. The encyclopedia of Middle East wars: the United States in the Persian Gulf, Afghanistan, and Iraq conflicts. Santa Barbara: ACB Clio, 2010. p. 761-2.

ATRAN, S. ISIS is a Revolution. AEON, 15 Dezembro 2015.

BAR, S. The Religious Sources of Islamic Terrorism. In: PERRY, M.; NEGRIN, H. The Theory and Practice of Islamic Terrorism - An Anthology. Nova Iorque: Palgrave MacMillan, 2008. p. 11-20.

BARR, J. Setting the Desert on Fire-T. E. Lawrence and Britain's Secret War in Arabia, 1916-1918. Londres: W. W. Norton \& Company, 2008.

A Line in the Sand-Britain, France and the Struggle that Shaped the Middle East. Londres: Simon \& Schuster, 2011.

BARROS, J. D. O Projeto de Pesquisa em História. Da escolha do tema ao quadro teórico. Petrópolis: Vozes, 2015.

BAUER, P. The European Mediterranean Policy after the Arab Spring: Beyond Values and Interests. Middle East Critique, v. 24, n. 1, p. 27-40, Fevereiro 2015.

BAZZAN, D. Primavera Árabe: a força da disseminação da informação pelo meio digital e sua forma de construção de sentido. Dissertação (Mestrado em Letras) USP. São Paulo. 2014.

BJORGO, T. (Ed.). Root causes of terrorism-Myths, reality and ways forward. Abingdon: Routledge, 2005.

BROCKOPP, J. Shari'a. In: MARTIN, R. Encyclopedia of Islam and the Muslim Wolrd. Nova Iorque: Macmillan Reference, v. II, 2004. p. 618-9.

BUTENSCHøN, N. Arab Citizen and the Arab State: The "Arab Spring” as a Critical Juncture in Contemporary Arab Politics. Democracy and Security, v. 11, n. 2, p. 111-128, Junho 2015. 
CASACA, P. The Conceptual Discussion on Terrorism. In: CASACA, P.; WOFL, S. Terrorism Revisited - Islamism, Political Violence and State-Sponsorship. Cham: Springer, 2017. p. 3-32.

CATHERWOOD, C. A Brief History of the Middle East - From Abraham to Arafat. Nova Iorque: Carroll and Graf, 2006.

CEPIK, M. A. Combate ao terrorismo e Estado no Brasil: avaliação crítica e sugestões preliminares. In: HERZ, M.; AMARAL, A. B. Terrorismo \& Relações Internacionais-Perspectivas e desafios para o século XXI. Rio de Janeiro: Editora PUC-Rio, 2010. p. 121-146.

CHOMSKY, N. Quem manda no mundo? 1ª ed. São Paulo: Crítica, 2017.

CLEMESHA, A. E. Análise do grupo Estado Islâmico. [Entrevista concedida a Paulo Moreira Leite e Florestan Fernandes Júnior]. Espaço Público, São Paulo, TV Brasil 2 mar 2015 .

COMBS, C.; SLANN, M. Encyclopedia of Terrorism. Revised. ed. Nova Iorque: Facts on File, 2007.

COOPER, B. New political religions, or, An analysis of modern terrorism. $1^{\text {a }}$. ed. Columbia: University of Missouri Press, 2004.

COSTA, R. P. Uma história da Síria do século XXI para além do sectarismo religioso. Dissertação (Mestrado em Letras) - USP. São Paulo. 2016.

CRENSHAW, M. The Causes of Terrorism. Comparative Politics, Nova Iorque, v. 13, n. 4, p. 379-399, julho 1981.

. Theories of Terrorism: Instrumental and Organizational Approaches. In: TERRORISM, T. O. Inside Terrorist Organizations. Nova Iorque: Columbia University Press, 1988. p. 13-31.

. The logic of terrorism: terrorist behavior as a product of strategic choice. In: REICH, W. Origins of terrorism: psychologies, ideologies, theologies, states of mind. Washington: Woodrow Wilson Center Press, 1998. p. 7-24.

Explaining Terrorism: Causes, Processes and Consequences. Oxford: Routledge, 2011.

Terrorism Research: The Record. International Interactions, v. 40, n. 4, p. 556567, Julho 2014.

CRONIN, A. K. Behind the Curve: Globalization and International Terrorism. International Security, v. 27(3), p. 30-58, 2002-2003.

DABASHI, H. The Arab Spring-The End of Postcolonialism. Londres: Zed Books, 2012.

DAVIDSON, L. Islamic Fundamentalism-An Introduction. Westport: Greenwood Press, 2003.

DE LA CORTE, L. La lógica del terrorismo. Madri: Alianza, 2006. 
Explaining Terrorism: A Psychosocial Approach. Perspectives on Terrorism, v. I, n. 2, p. 6-15, 2007.

DEMANT, P. O Mundo Muçulmano. São Paulo: Contexto, 2004.

Islam vs. Islamism-the dilemma of the Muslim world. Westport: Praeger, 2006.

DERIAN, J. Terrorismo no século XXI: real, virtual ou banal? In: HERZ, M.; AMARAL, A. Terrorismo \& Relações Internacionais-Perspectivas e desafios para o século XXI. Rio de Janeiro: PUC-Rio, 2010. p. 319-338.

DINIZ, E. A guerra contra a Al-Qaeda: avaliação e perspectivas. In: HERZ, M.; AMARAL, A. B. D. Terrorismo \& Relações Internacionais-Perspectivas e desafios para o século XXI. Rio de Janeiro: PUC-Rio, 2010. p. 163 a 212.

DYER, C. The ISIS Crisis - What you really need to know. Chicago: Moody Publishers, 2013.

EGERTON, F. Jihad in the west: the rise of militant Salafism. Cambridge: Cambridge University Press, 2011.

ELIAS, J. Islamismo. Lisboa: Edições 70, 1999.

ETHEREDGE, L. (Ed.). Iraq. 1ª ed. Nova Iorque: Britannica Educational, 2011.

FELTON, J. The Contemporary Middle East: A Documentary History. Washington: CQ Press, 2008.

FERDOWS, A.; WEBER, P. Fundamentalism. In: HAWKESWORTH, M.; KOGAN, M. Encyclopedia of Government and Politics. Londres: Routledge, v. I, 1992. p. 179192.

FERREIRA, P. A. O Novo Terrorismo. Lisboa: Prefácio, 2006.

FIRESTONE, R. Jihad-The Origin of Holy War in Islam. Oxford: Oxford University Press, 1999.

FISHMAN, B. After Zarqawi: The Dilemmas and Future of Al Qaeda in Iraq. The Washington Quarterly, Washington DC, v. 29, n. 4, p. 19-32, 2006.

FONTAN, V. Voices From Post-Saddam Iraq. Living with Terrorism, Insurgency and New Forms of Tyranny. Westport: Praeger Security International, 2009.

FUND FOR PEACE. Fragile States Index. Fund for Peace, Washington, 2007. Disponivel em: <https://fragilestatesindex.org/country-data/>. Acesso em: 02 Setembro 2019.

GABRIEL, M. Islam and Terrorism - the truth about ISIS, the Middle East and Islamic Jihad. Lake Mary: Charism Media, 2015.

GELVIN, J. The Other Arab Nationalism: Syrian/Arab Populism in Its Historical and International Contexts. In: JANKOWSKI, J.; GERSHONI, I. Rethinking Nationalism in the Arab World. Nova Iorque: Columbia University Press, 1997.

GERGES, F. ISIS - A history. Oxfordshire: Princeton University Press, 2016.

GHAREEB, E. Historical Dictionary of Iraq. Oxford: Scarecrow Press, 2004. 
GOEDE, M. D. Hawala discourses and the war on terrorist finance. Society and Space, v. XXI, p. 513^532, 2003.

GÓMEZ, J. M. A Financial Profile of the Terrorism of Al-Qaeda and its Affiliates. Perspectives on Terrorism, v. IV, n. 4, p. 3-27, Outubro 2010.

GONZÁlEZ CALLEJA, E. Ciclos de protesta y ondas de temor. Aportaciones a una propuesta de periodización de la. In: GONZÁLEZ CALLEJA, E. Políticas del miedo. Un balance del terrorismo en Europa. Madri: Biblioteca Nueva, 2003. p. 33-76.

GRIEVE, P. A Brief Guide to Islam. Nova Iorque: Carroll \& Graf Publishers, 2006.

GRIFFIN, M. Islamic State-Rewriting History. Londres: Pluto Press, 2016.

GROSBY, S. Nationalism-A very short introduction. Oxford: Oxford University Press, 2005.

GUIDÈRE, M. O Choque das Revoluções Árabes. Lisboa: Edições Almedina, 2012.

HALAWI, M.; GHAZZAL, Z. Alawi. In: MATTAR, P. Encyclopedia of the Modern Middle East and North Africa. Farmington Hills: MacMillan Reference, v. I, 2004.

HAllidAY, F. Two Hours that Shook the World - September 11, 2001: Causes \& Consequences. Londres: Saqi Books, 2002.

HANNE, O.; DE LA NEUVILLE, T. Der Islamische Staat - Anatomie des neuen Kalifats. Dortmund: Readbox Publishing, 2015.

HASHIM, A. Insurgency in Iraq 2003-10. In: RICH, P.; DUYVESTEYN, I. The Routledge handbook of insurgency and counterinsurgency. Abingdon: Routledge, 2012. p. 172-182.

HASHMI, S. Jihad. In: MARTIN, R. Encyclopedia of Islam and the Muslim World. Nova Iorque: MacMillan Reference, v. I, 2004. p. 377-379.

HEDIN, C.; JANSON, T.; WESTERLUND, D. Da'wa. In: MARTIN, R. Encyclopedia of Islam and the Muslim World. Nova Iorque: Macmillan Reference, v. I, 2004. p. $170-4$.

HENDERSON, H. Global Terrorism. Nova Iorque: Facts On File, 2004.

HERBST, P. Talking Terrorism: A Dictionary of the Loaded Language of Political Violence. Westport: Greenwood Press, 2003.

HIGGINS, A. Kharijites, Khawarij. In: MARTIN, R. Encyclopedia of Islam and the Muslim World. Nova Iorque: Macmillan Reference, v. I, 2004. p. 390.

HINNEBUSCH, R. What Went Wrong: Understanding the Trajectory of Syria's Conflict. In: MATAR, L.; KADRI, A. Syria: From National Independence to Proxy War. Cham: Palgrave Macmillan, 2019. p. 29-52.

HIRO, D. War without End: The Rise of Islamist Terrorism and Global Response. Londres: Routledge, 2002.

HOFFMAN, B. Inside Terrorism. Nova Iorque: Columbia University Press, 2006. 
HOLBROOK, D. Al-Qaeda and the Rise of ISIS. Survival - Global Politics and Strategy, v. LVII, n. 2, p. 93-104, Março 2015.

HOLliDAY, J. Syria's armed opposition (Middle East Security Report No. 3). Institute for the Study of War. Washington. 2012.

HUDA, Q. Orientalism. In: MARTIN, R. Encyclopedia of Islam and the Muslim World. Nova Iorque: MacMillan Reference, v. II, 2004. p. 515-6.

HUNT, C. The History of Iraq. Westport: Greenwood Press, 2005.

HUNTINGTON, S. The clash of civilizations and the remaking of world order. Nova Iorque: Simon \& Schuster, 1996.

INGLEHART, R.; NORRIS, P. The True Clash of Civilizations. Foreign Policy 135, Março-Abril 2003. 68-9.

INGLEHART, R.; WELZEL, C. Modernization, Cultural Change, and Democracy. Nova Iorque: Cambridge University Press, 2005.

ISMAEL, T.; ISMAEL, J. The Iraqi Predicament: People in the quagmire of power politics. Londres: Pluto Press, 2004.

, J. Iraq in the Twenty-First Century-Regime change and the making of a failed state. Abingdon: Routledge, 2015.

JACKSON, R. Fifty Key Figures in Islam. Londres: Routledge, 2006.

JACKSON, R. Constructing Enemies: 'Islamic Terrorism' in Political and Academic Discourse. Government and Opposition, Oxford, v. 42, n. 3, p. 394-426, 2007.

JAQUES, R. K. Ibn Khaldun. In: MARTIN, R. Encyclopedia of Islam and the Muslim World. Nova Iorque: Macmillan Reference, v. I, 2004. p. 335-6.

JAVAlOY, F.; RODRÍGUEZ, A.; ESPELT, E. Comportamiento colectivo y movimientos sociales. Madri: Prentice Hall, 2003.

JUBRAN, S. A.-C. Para uma Romanização Padronizada de Termos Árabes em Textos de Língua Portuguesa. Tiraz, São Paulo, v. 1, p. 16-29, 2004.

KAMALI, M. The Middle Path of Moderation in Islam - The Qur'ānic Principle of Wasațiyyah. Oxford: Oxford University Press, 2015.

KAMRAVA, M. The Modern Middle East-A Political History since the First World War. Berkeley: University of California Press, 2005.

KAUSCH, K. Geopolitics and Democracy in the Middle East. Madri: Frida, 2015.

KEEGAN, J. The Iraq War. Nova Iorque: Alfred A. Knoff, 2004.

KUBBA, L. Lessons from Iraq. In: PAYA, A.; ESPOSITO, J. Iraq, Democracy and the Future of the Muslim World. Londres: Routledge, 2010.

KUSHNER, H. Encyclopedia of Terrorism. Thousand Oaks: Sage, 2003.

LAOUST, H. Ibn Taymiyya. In: LEWIS, B., et al. The Encyclopaedia of Islam. Leiden: Brill, v. III, 1987. p. 951-5. 
LAPIDUS, I. M. A History of Islamic Societies. Nova Iorque: Cambridge University Press, 2014.

LAQUEUR, W. A history of terrorism. New Brunswick: Transaction, 1977.

LARA, A. D. S. Ciência Política: Estudo da Ordem e da Subversão. Lisboa: Instituto Superior de Ciências Sociais e Políticas da Universidade de Lisboa, 2015.

LAWRENCE, B. (Ed.). Messages to the World: The Statements of Osama bin Laden. Londres: Verso, 2005.

LAWSON, F. The Assistance Front Versus the Popular Protection Units Versus the Islamic State: Reciprocal Mobilization and the Ascendance of Violent Non-state Actors in the Syrian Civil War. In: OKTAV, Ö.; DEL, E.; KURS,UN, A. Violent Non-state Actors and the Syrian Civil War - The ISIS and YPG Cases. Cham: Springer, 2018. p. 91-106.

LAWSON, F.; ST JOHN, R. B. Syria. In: MATTAR, P. Encyclopedia of the Modern Middle East and North Africa. Farmington Hills: MacMillan Reference, v. III, 2004. p. 2130-2135.

LEUPRECHT, C. et al. Containing the Narrative: Strategy and Tactics in Countering the Storyline of Global Jihad. Journal of Policing, Intelligence and Counter Terrorism, v. V, n. 1, p. 42-57, Agosto 2011.

LEWIS, B. A Crise do Islã-Guerra santa e terror profano. Rio de Janeiro: Zahar, 2004.

LINDNER, E. Making Enemies: Humiliation and International Conflict. Londres: Praeger, 2006.

LINDSEY, J. Daily Life in The Medieval Islamic World. Westport: Greenwood Press, 2006.

LISTER, C. The Syrian Jihad. Londres: Hurst, 2015.

LONE, F. A. Islamic Banks and Financial Institutions. Nova Iorque: Palgrave Macmillan, 2016.

LUND, A. Divided they stand: An overview of Syria's political opposition factions. Uppsala: European Foundation for Progressive Studies, 2012.

MANSBACH, R.; TAYLOR, K. Introduction to Global Politics. 2 ${ }^{\text {a }}$. ed. Londres: Routledge, 2012.

MARQUADT, E.; HEFFELFINGER, C. Terrorism \& Political Islam: Origins, Ideologies, and Methods - A Counterterrorism Textbook. West Point: Department of Social Sciences, US Army, 2008.

MARTIN, R. Encyclopedia of Islam and the Muslim World. Nova Iorque: Macmillan Reference, 2004.

MATAR, D.; KHATIB, L. Hizbullah's communication and political evolution. In: KHATIB, L.; MATAR, D.; ALSHAER, A. The Hizbullah phenomenon: politics and communication. Oxford: Oxford University Press, 2014. p. 1-12. 
MATTAR, P. The Encyclopedia of the Modern Middle East and North Africa. $2^{\mathrm{a}}$. ed. Nova Iorque: Macmillan Reference, v. I, 2004.

MAURER, B. Re-formatting the economy. In: LAHOUD, N.; JOHNS, A. Islam in World Politics. Abingdon: Routledge, 2005. p. 54-66.

MCCANTS, W. The ISIS Apocalypse - The History, Strategy and Doomsday Vision of the Islamic State. Nova Iorque: St. Martin Press, 2015.

MELAMED, A. Inside the Middle East: Making Sense of the Most Dangerous and Complicated Region on Earth. Nova Iorque: Skyhorse, 2016.

MILTON-EDWARDS, B. Contemporary Politics in the Middle East. Cambridge: Polity Press, 2011.

MOSCOVICI, S. Psicología de las minorías activas. Madri: Morata, 1996.

MOSCOVICI, S.; MUGNY, G.; PÉREZ, J. La influencia social inconciente. Estudios de psicología social experimental. Barcelona: Anthropos, 1991.

MOTZKI, H. Hadith. In: MARTIN, R. Encyclopedia of Islam and the Muslim World. Nova Iorque: Macmillan Reference, v. I, 2004. p. 285-8.

NAJI, A. B. Management of Savagery: The Most Critical Stage through Which the Umma Will Pass. Cambridge. 2006. Original Arabic version published by the Center for Islamic Studies and Research, 2004.

NAYLOR, D. Al Qaeda in Iraq. Nova Iorque: Nova Science, 2009.

NEWMAN, E. Weak States, State Failure, and Terrorism. Terrorism and Political Violence, v. XIX, n. 4, p. 463-488, Outubro 2007.

NYDELL, M. Understanding Arabs - A Contemporary Guide to Arab Society. Boston: Intercultural Press, 2012.

OKTAV, O.; DAL, E.; KURS,UN, A. Reframing and Reassessing the VNSAs in Syrian Conflict: An Introduction. In: OKTAV, O.; DAL, E.; KURS,UN, A. Violent Nonstate Actors and the Syrian Civil War. Cham: Springer, 2018. p. 1-34.

PARENTI, C. Tropic of Chaos-Climate Change and the New Geography of Violence. Nova Iorque: Bold Type Books, 2001.

PAZ, R. Arab Volunteers Killed in Iraq: An Analysis. The Project for the Research of Islamic Movements (PRISM), Março 2005. Disponivel em: <http://www.eprism.org/images/PRISM_no_1_vol_3_-_Arabs_killed_in_Iraq.pdf $>$. Acesso em: 21 Novembro 2018.

PERRY, M.; NEGRIN, H. The Theory and Practice of Islamic Terrorism - An Antology. Nova Iorque: Palgrave MacMillan, 2008.

PETERSON, D. In: MARTIN, R. Encyclopedia of Islam and the Muslim World. Nova Iorque: MacMillan Reference, v. I, 2004. p. 255.

PEVLIN, J. Ibn Taymiiyyah. In: MARTIN, R. Encyclopedia of Islam and the Muslim World. Nova Iorque: MacMillan Reference, v. II, 2004. p. 338-9. 
PHILLIPS, C. After the Arab Spring: power shift in the Middle East?: Syria's bloody Arab Spring. LSE Research Online, Londres, p. 37-42, Maio 2012.

PILLAR, P. Terrorism and U.S. Foreign. Washington: Brookings, 2001.

PLEBANI, A. The unfolding legacy of al-Qa'ida in Iraq: from al-Zarqawi to the new Islamic Caliphate. Milão: Istituto per gli Studi di Politica Internazionale, 2014.

POLK, W. Understanding Iraq - A Whistlestop Tour from Ancient Babylon to Occupied Baghdad. Londres: I.B. Tauris, 2006.

RAHMAN, F. O Islamismo. Lisboa: Edições Arcádia, 1966.

RAPOPORT, D. Assassination \& Terrorism. Toronto: Canadian Broadcasting Corporation, 1971.

Fear and Trembling: Terrorism in Three Religious Traditions. American Political Science Review, v. 78, n. 3, p. 658-77, 1984.

The Four Waves of Modern Terrorism. In: CRONIN, A.; LUDES, J. Attacking Terrorism: Elements of a Grand Strategy. Washington DC: [s.n.], 2004. p. 46-73.

REILly, J. A. Fragile Nation, Shattered Land - The Modern History of Syria. Londres: I.B. Tauris, 2016.

REINARES, F. Terrorismo y antiterrorismo. Barcelona: Paidós, 1998.

Nationalist separatism and terrorism in comparative perspective. In: BJORG, T. Root Causes of Terrorism-Myths, reality and ways forward. Abingdon: Routledge, 2005. p. 119-130.

RENTZ, G. The Birth of the Islamic Reform Movement in Saudi Arabia: Muhammad b. 'Abd al-Wahhab (1703/4-1792) and the Beginnings of Unitarian Empire in Arabia. Londres: Arabian Publishing, 2004.

REY, M. Histoire de la Syrie-XIXe - XXIe siècle. Paris: Fayard, 2018.

RICHARDSON, L. What Terrorists Want-Understanding the Enemy, Containing the Threat. Nova Iorque: Random House, 2007.

RICKS, T. Fiasco-The American Military Adventure in Iraq. Nova Iorque: Penguin, 2006.

ROBERTS, P. France, Middle East Policy. In: TUCKER, S. The encyclopedia of Middle East wars: the United States in the Persian Gulf, Afghanistan, and Iraq conflicts. Santa Barbara: ABC-CLIO, 2010. p. 463-466.

ROGAN, E. The Arabs - A History. Nova Iorque: Basic Books, 2009.

RYAN, M. Hot Issue: Dabiq: What Islamic State's New Magazine Tells Us about Their Strategic Direction, Recruitment Patterns and Guerrilla Doctrine. The Jamestown Foundation, 1 Agosto 2014. Disponivel em: <https://jamestown.org/program/hotissue-dabiq-what-islamic-states-new-magazine-tells-us-about-their-strategicdirection-recruitment-patterns-and-guerrilla-doctrine/>. Acesso em: 18 Junho 2019.

SAEED, A. Umma. In: MARTIN, R. Encyclopedia of Islam and the Muslim World. Nova Iorque: Macmillan Reference, v. II, 2004. p. 705-6. 
SAGEMAN, M. Understanding terrorist networks. Pennsylvania: University of Pennsyvania Press, 2004.

Leaderless jihad: Terror networks in the twenty-first century. Filadélfia: University of Pennsylvania Press, 2008.

SCHELLING, T. Arms and Influence. New Haven: Yale University Press, 1966.

SCHMID, A. The Routledge Handbook of Terrorism Research. Abingdon: Routledge, 2011.

SCUPIN, R. Cultural Anthropology-A Global Perspective. 9a . ed. Londres: Pearson, 2016.

SEDGWICK, M. Al-Qaeda and the Nature of Religious Terrorism. Terrorism and Political Violence, v. XVI, n. 4, p. 795-814, Agosto 2010.

SEKULOV, J. Rise of ISIS - A threat we can't ignore. Nova Iorque: Howard Books, 2014.

SHARKEY, H. A History of Muslims, Christians, and Jews in the Middle East. Cambridge: Cambridge University Press, 2017.

SILVA, K. V.; SILVA, M. H. Dicionário de Conceitos Históricos. São Paulo: Contexto, 2009.

SILVA, M. Antisemitism and the Global Jihad. In: CASACA, P.; WOLF, S. Terrorism Revisited - Islamism, Political Violence and State-Sponsorship. Cham: Springer, 2017. p. 157-179.

SILVA, T. D. A. E. Islão e Fundamentalismo Islâmico-das Origens ao Século XXI. Lisboa: Pactor, 2016.

SIMON, R.; SLUGLETT, P. Ba'at, Al-. A pan-Arab political party. In: MATTAR, P. Encyclopedia of the Modern Middle East and North Africa. $2^{\text {a }}$. ed. Farmington Hills: MacMillan Reference, v. I, 2004. p. 412-414.

SOHAIL, H. Fundamentalism. In: MARTIN, R. Encyclopedia of Islam and the Muslim World. Nova Iorque: Macmillan Reference, v. I, 2004. p. 261-3.

. Jihad. In: MARTIN, R. Encyclopedia of Islam and the Muslim World. Nova Iorque: MacMillan , v. I, 2004. p. 377-9.

SOTTIMANO, A. Syria in the 'Resistance Front': Persistence Through Reconfiguration? In: MATAR, L.; KADRI, A. Syria: From National Independence to Proxy War. Cham: Palgrave Macmillan, 2019. p. 161-182.

SPAAIJ, R. The Enigma of Lone Wolf Terrorism: An Assessment. Studies in Conflict \& Terrorism, v. 33, n. 9, p. 854-870, Agosto 2010.

STARR, S. Revolt in Syria: eye-witness to the uprising. Nova Iorque: Columbia University Press, 2012.

STEIGERWALD, D. 'Ali (600-661). In: MARTIN, R. Encyclopedia of Islam and the Muslim World. Nova Iorque: Macmillan Reference, v. I, 2004. p. 35-8. 
STERN, J.; BERGER, J. M. ISIS - The State of Terror. Nova Iorque: Harper Collins, 2015.

STOKES, J. The Encyclopedia of the Peoples of Africa and the Middle East. Nova Iorque: Facts on File, 2009.

TAJFEL, H. Human Groups and Social Categories: Studies in Social Psychology. Cambridge: Cambridge University Press, 1981.

TARROW, S. Struggle, politics and reforms: collective action, social movements and cycles of protest. Ithaca: Cornell University, 1989.

TIBI, B. Religious extremism or religionization of politics? - The ideological foundations of Political Islam. In: FRISCH, H.; INBAR, E. Radical Islam and International Security - Challenges and Responses. Abingdon: Routledge, 2008. p. 11-37.

TOVELLI, S.; VARVELLI, A. New trends in north African jihadism: 'Ansar Al-sharia in Tunisia and Libya. In: PLEBANI, A. New (and old) patterns of jihadism: alQa'ida, the Islamic State and beyond. Milão: Instituto per gli Studi di Politica Internazionale, 2014. p. 45-71.

TRAVERSO, E. The New Faces of Fascism - Populism and the Far Right. Londres: Verso, 2019.

TURKU, H. The Destruction of Cultural Property as a Weapon of War - ISIS in Syria and Iraq. Cham: Palgrave MacMillan, 2018.

TURNER, J. Rediscovering the social group: A self-categorizatino theory. Nova Jersey: Blackwell, 1987.

VIOTTI, P.; KAUPPI, M. International Relations and World Politics. Londres: Pearson, 2013.

VISENTINI, P. O Grande Oriente Médio: Da descolonização à Primavera Árabe. Rio de Janeiro: Elsevier, 2014.

WALLS, E. Waves of Modern Terrorism: Examining the Past and Predicting the Future. Tese (mestrado em estudos liberais) - Universidade de Georgetown. Washington: [s.n.], 2017.

WARRICK, J. Black Flgas-The Rise of ISIS. Norwell: Anchor, 2016.

WEINER, R. The Financing of International Terrorism. Terrorism and Violence Crime, Section, Criminal Division, U.S. Department of Justice. Washington, p. 3. 2001.

WEISS, M.; HASSAN, H. ISIS - Inside the Army of Terror. Nova Iorque: Regan Arts, 2016.

WELCH, T. Theology, heroism, justice, and fear: an analysis of ISIS propaganda magazines Dabiq and Rumiyah. Dynamics of Asymmetric Conflict, p. 1-13, Setembro 2018.

WIKTOROWICZ, Q. The New Global Threat: Transnational Salafis and Jihad. Middle East Policy, v. VIII, n. 4, p. 18-38, 2001. 
Islamic Activism: A Social Movement Theory Approach. Bloomington: Indiana University Press, 2014.

WILKINSON, P. Terrorism Versus Democracy: The Liberal State Response. Londres: Frank Class, 1976.

WILNER, A. Opportunity Costs or Costly Opportunities? The Arab Spring, Osama Bin Laden, and Al-Qaeda's African Affiliates. Perspectives on Terrorism, v. V, n. 3 e 4, Setembro 2011.

WRIGHT, R. Dreams and Shadows: the Future of the Middle East. Londres: Penguin Press, 2008.

YASSIN-KASSAB, R.; AL-SHAMI, L. Burning Country - Syrians in Revolution and War. Londres: Pluto Press, 2016.

ZAMAN, M. Q. Caliphate. In: MARTIN, R. Encyclopedia of Islam. Nova Iorque: Macmillan Reference, v. I, 2004. p. 116-123. 